Portland State University

PDXScholar

Fall 12-28-2017

\title{
Workers of the Word Unite!: The Powell's Books Union Organizing Campaign, 1998-2001
}

Ryan Thomas Wisnor

Portland State University

Follow this and additional works at: https://pdxscholar.library.pdx.edu/open_access_etds

Part of the Public History Commons, and the Unions Commons

Let us know how access to this document benefits you.

\section{Recommended Citation}

Wisnor, Ryan Thomas, "Workers of the Word Unite!: The Powell's Books Union Organizing Campaign, 1998-2001" (2017). Dissertations and Theses. Paper 4162.

https://doi.org/10.15760/etd.6050

This Thesis is brought to you for free and open access. It has been accepted for inclusion in Dissertations and Theses by an authorized administrator of PDXScholar. Please contact us if we can make this document more accessible: pdxscholar@pdx.edu. 
Workers of the Word Unite!:

The Powell's Books Union Organizing Campaign, 1998-2001

by

Ryan Thomas Wisnor

A thesis submitted in partial fulfillment of the requirements for the degree of

\author{
Master of Arts \\ in \\ History
}

Thesis Committee:

David A. Horowitz, Chair

Patricia Schechter

Catherine McNeur

Laurie Mercier

Portland State University

2017 
(C) 2017 Ryan Thomas Wisnor 


\begin{abstract}
The labor movement's groundswell in the 1990s accompanied a period of intense competition and conglomeration within the retail book sector. Unexpectedly, the intersection of these two trends produced two dozen union drives across the country between 1996 and 2004 at large retail bookstores, including Borders and Barnes \& Noble. Historians have yet to fully examine these retail organizing contests or recount their contributions to the labor movement and its history, including booksellers' pioneering use of the internet as an organizing tool. This thesis focuses on the aspirations, tactics, and contributions of booksellers in their struggles to unionize their workplaces, while also exploring the economic context surrounding bookselling and the labor movement at the end of the twentieth century. While the United Food and Commercial Workers (UFCW) auspiciously announced a national campaign in 1997 to organize thousands of bookstore clerks, the only successfully unionized bookstore from this era that remains today is the Powell's Books chain in Portland, Oregon with over 400 workers represented by the International Longshore and Warehouse Union (ILWU) Local 5.
\end{abstract}

Local 5's successful union campaign at Powell's Books occurring between 1998 and 2000 is at the center of this study and stands out as a point of light against a dark backdrop of failed union attempts in the retail sector during the latter decades of the twentieth century. This inquiry utilizes Local 5's internal document archive and the collection of oral histories gathered by labor historians Edward Beechert and Harvey Schwartz in 2001 and 2002. My analysis of these previously unexamined records demonstrates how Powell's efforts to thwart the ILWU campaign proved a decisive 
failure and contributed to the polarization of a super majority of the workforce behind Local 5. Equally, my analysis illustrates how the self-organization, initiative, and unrelenting creativity of booksellers transformed a narrow union election victory to overwhelming support for the union's bargaining committee. Paramount to Local 5's contract success was the union's partnership with Portland's social justice community, which induced a social movement around Powell's Books at a time of increased political activity and unity among the nation's labor, environment, and anti-globalization activists. The bonds of solidarity and mutual aid between Local 5 and its community allies were forged during the World Trade Organization (WTO) demonstrations in Seattle in 1999 and Portland's revival of May Day in 2000. Following eleven work stoppages and fiftythree bargaining sessions, the union acquired a first contract that far exceeded any gains made by the UFCW at its unionized bookstores. The Powell's agreement included improvements to existing health and retirement benefits plus an 18 percent wage increase for employees over three years.

This analysis brings to light the formation of a distinct working-class culture and consciousness among Powell's booksellers, communicated through workers' essays, artwork, strikes, and solidarity actions with the social justice community. It provides a detailed account of Local 5's creative street theater tactics and work stoppages that captured the imagination of activists and the attention of the broader community. The conflict forced the news media and community leaders to publicly choose sides in a labor dispute reminiscent of struggles not seen in Portland since the 1950s. Observers of all political walks worried that the Portland cultural and commercial intuition would collapse under the weight of the two-year labor contest. My research illustrates the tension among 
the city's liberal and progressive populace created by the upstart union's presence at prominent liberal civic leader Michael Powell's iconic store and how the union organized prominent liberal leaders on the side of their cause. It concludes by recognizing that Local 5's complete history remains a work in progress, but that its formation represents an indispensable Portland contribution to the revitalized national labor movement of the late 1990 s. 


\section{Dedication}

To the booksellers of ILWU Local 5 


\section{Acknowledgements}

I am truly grateful for all the encouragement and support that I received from so many scholars, fellow students, and family members throughout the research and writing of this thesis. First, I must thank historian Edward Beechert for his foresight in beginning the ILWU Local 5 Oral History Project. Ed's interviews were invaluable to my writing and they created the foundation for my exploration into the subject. Historian Harvey Schwartz's interviews with ILWU officials were equally important to my work and his encouragement was especially meaningful.

I must emphasize how appreciative I am of Local 5 for providing me access to its document archive. Additional thanks are due to all the booksellers who helped train and answer my questions during my short stint as a cashier at Powell's Books. This thesis would have remained only a dream had it not been for Bryan Bingold and Ron Solomon, who made it possible for me to view and digitize over 500 documents from the union's early years. While the research process was full of exciting discoveries, nothing was more thrilling than sifting through the writing and imagery created by booksellers for their union campaign. Ryan Takas and Cal Hudson were always quick to respond to my inquiries and were helpful sounding boards for my writing. I am truly grateful to Mary Winzig, Jeff Hensley, and Stephen Strausbaugh for sharing with me their stories, making sure I did not get off track. No thesis is possible without the work of amazing archivists. In this regard, I am very much indebted to ILWU Librarian and Archivist Robin Walker and Portland City Archivist Mary Hansen.

I want to sincerely thank my thesis committee and its chair David A. Horowitz, who served as my advisor. Through David's U.S. Cultural History courses and our 
reading conferences on labor history, he read the lion's share of my graduate writing. I am truly fortunate to have had a scholar such as David encourage, challenge, and guide my thesis pursuit. I also want to acknowledge the influential role Patricia A. Schechter and Catherine McNeur played on my instruction in the field of Public History and for the challenging questions they posed to my thesis. I will profoundly miss their classrooms and the opportunities they created to connect the historian craft to the community at large. I consider it an honor to have had labor and oral historian Laurie Mercier on the committee. Laurie's writings were an inspiration for my graduate studies and I truly appreciate her insightful questions and comments to my thesis.

I owe heartfelt appreciation to my fellow graduate students in the Department of History. In particular, I want to thank my writing group of skilled historians: Taylor Rose, Melissa Lang, David-Paul Hedburg, and Katherine Nelson. I also want to recognize the very talented Joshua Justice, who I collaborated with on multiple public history projects.

I owe the foundation of my historical training to Eileen Findlay, who served as my mentor during my undergraduate studies at American University and in the years that followed.

Financial support for my graduate studies was generously provided by the Stephanie K. Oliver Graduate Award, the Barney Burke History Scholarship, and Jeanne and Ugo Pezzi.

Finally, my deepest gratitude is reserved for my loving partner Holly and our daughter Evelyn, who accompanied me on this long journey every step of the way. The completion of this thesis became a family endeavor and its accomplishment would not 
have been possible without Holly's hard work. In particular, her confidence and reassurance that I would someday complete this thesis despite all the limitations of time. I will certainly never forget the mornings spent drafting chapters before dawn as I cradled a sleepy newborn Evelyn in my arms. 


\section{Table of Contents}

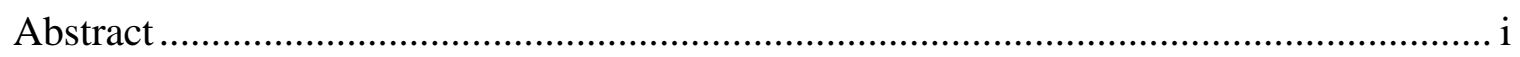

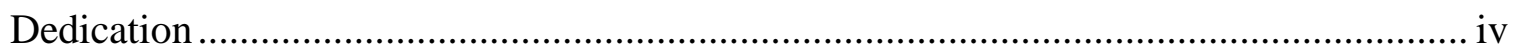

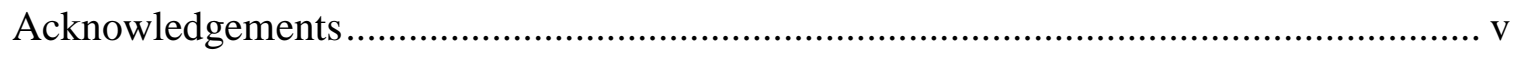

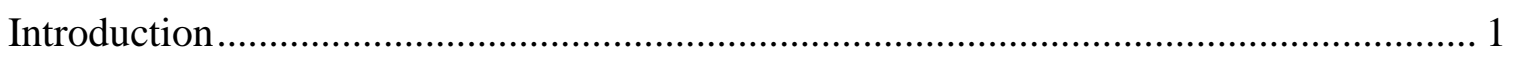

Chapter 1:

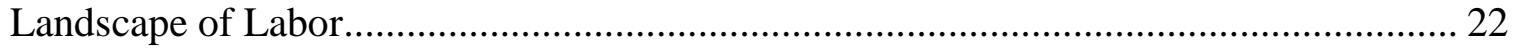

Chapter 2:

Historical Developments in the Retail Book Sector .................................................. 52

Chapter 3:

Booksellers and Dockworkers: Organizing the Union at Powell's Books

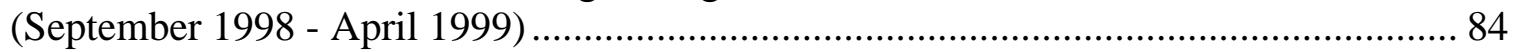

Chapter 4:

"The Street Drives the Table": Bargaining a First Contract ....................................... 119

Chapter 5:

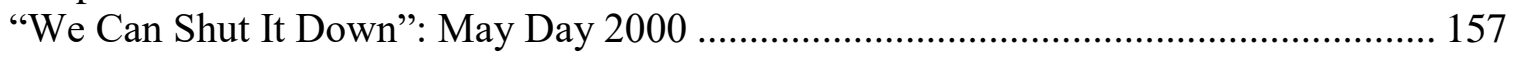

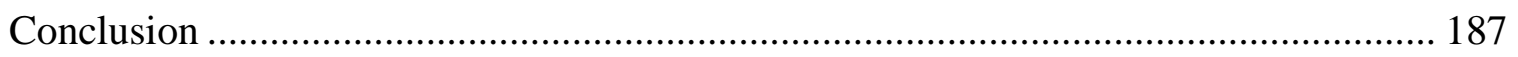

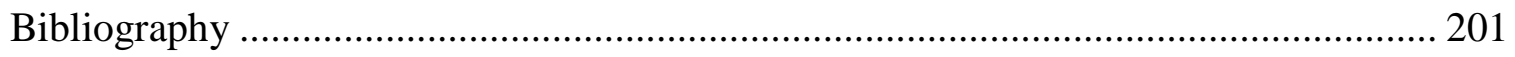




\section{Introduction}

"The taproot of its [the labor movement] resilience has been the workers' daily experience and the solidarities nurtured by that experience, which have at best encompassed a lush variety of beliefs, loyalties, and activists within a common commitment to democratic direction of the country's economic and political life."

- David Montgomery, The Fall of the House of Labor

"Those are nothing but a bunch of anarchists," a Portland, Oregon police officer dismissively characterized a rally of employees on strike at Powell's Books. It was May Day 2000 and while the recently unionized workers picketed outside the hallowed independent bookstore, management locked the doors at the store's iconic entrance as riot police surrounded the protesters. Contract negotiations had dragged on for nine months with no sign of ending, prompting a strike by the booksellers. As tensions rose outside the store of prominent liberal business figure Michael Powell, the echoing chant of "I-LW-U!" grew increasingly louder from a crowd marching up SW Tenth Avenue to join the rally. The police officer apparently hoped the warning about "anarchists" would dissuade the dockworkers, in town for the International Longshore and Warehouse Union (ILWU) convention, from joining the bookstore picket line.

When the convention delegates arrived at West Burnside Street and Tenth Avenue, a police line blocked their progress. "Those are our people," replied ILWU president, Brian McWilliams, a reference to the picketing bookstore workers who recently unionized and chartered ILWU Local 5. "We're going across," McWilliams stated as he stepped forward in front of three hundred longshoremen seeking to join the picket line. At that point, a riot gear clad officer swung a club at the fifty-year-old union president. The wooden stick narrowly missed McWilliams, most likely avoiding a serious

\footnotetext{
${ }^{1}$ David Montgomery, The Fall of the House of Labor (New York: Cambridge University Press, 1987), 8.
} 
melee. Immediately, the officer in charge pulled the foolhardy cop aside and allowed the ILWU contingent to join the picket line. With the police in retreat, Local 5 forced Powell's Books to close for the day, for only the second time in its twenty-nine-year history.

The two-day strike at Powell's Books that began on May Day 2000 remains a milestone in Portland's labor history and continues to hold folklore status among many in the city's progressive and radical communities. Participants and those who observed the scene at Powell's have been quick to share their accounts of the confrontation and remember the day when hundreds of burly longshoremen, alongside radicals freshly bruised by encounters with horse mounted officers, confronted the police on behalf of the comparatively and seemingly diminutive bookstore clerks. The union campaign existed as part and parcel of a reinvigorated labor movement as well as an emboldened global social justice movement that revitalized International Workers' Day and street protest. Ultimately, for the bookstore employees and their union, ILWU Local 5, the May Day strike and street action precipitated a crucial momentum shift in contract negotiations that rebounded to the advantage of the union and its unique grouping of progressive allies.

\section{Booksellers, the Emergence of Corporate Retailing, and Employee Activism}

May Day 2000 represents a significant historical event because it serves as an entry point into an investigation of several social and economic forces that converged in the Pacific Northwest at the turn of the twenty-first century. During the preceding two decades, the federal government had distanced itself from many of the policies of the welfare state and moved toward a free market, laissez-faire economic model. This included the ratification of the North American Free Trade Agreement (NAFTA) in 1994, 
which unified Canada, the United States, and Mexico into a single economic trade zone, and the World Trade Organization (WTO) a year later. During these years, public sector unions in Latin America, Asia, Europe, and elsewhere engaged in autonomous street and political actions to challenge austerity measures, the privatization of national resources, and free trade policies implemented by their governments often with the coordination of international financial agencies. While neoliberal trade agreements appeared to reflect the agenda of multinational corporations and promised enhanced consumer purchasing power through lower tariffs and the removal of national trade and investment restrictions, it spurred previously localized anti-corporate grassroots and progressive movements to act in solidarity. One example was the international movement to defend the Zapatista peasant uprising in Mexico that commenced on the first day of the NAFTA agreement. Later, the multitude of resistance movements representing environmental, labor, consumer, anarchist, and progressive causes captured headlines when they joined together to disrupt the WTO at its 1999 conference in Seattle, Washington. Similar to Portland's May Day demonstration six months later, Powell's Books workers marched in the streets with fellow unionists, environmentalists, and radicals at what became remembered as the Battle of Seattle.

Worker unrest within the national retail bookselling sector, including at Powell's Books, paralleled a period of intense corporate expansion, acquisition, and competition in the field that arose in the 1990s, preceding the rise of internet retailing in the following decade. As Borders Books and Barnes \& Noble struggled to capture a greater share of the market, the United Food and Commercial Workers International Union (UFCW) made several efforts with minimal success at organizing bookstore employees between 1996 
and 2004. After two previous organizing drives and an eight-month campaign that began in September 1998, Powell's Books workers voted 161 to 155 in favor of union representation by the ILWU the following April.

Booksellers at Borders, Barnes \& Noble, and Powell's organized unions to respond to the economic pressures common among all retail workers but also to address employee autonomy in an industry that had become increasingly centralized and incorporated. The organizing campaigns among booksellers in the mid-1990s and early2000s remain significant because employees initiated the union drives while unions of this period were finding little success organizing elsewhere in the retail sector, particularly within big-box stores.

The progressive and radical movements that embraced the "Spirit of Seattle" carried their grassroots, anti-globalization initiatives into the new century with optimism and greater resolve. West Coast urban centers such as Portland fostered both progressive middle-class and radical anti-capitalist causes between 2000 and 2003. In a signal of the optimism and common cause among Portland's political left that occurred following the embittered 2000 presidential election, the Green Party’s Ralph Nader organized a "Democracy Rising: People Have the Power Tour." The tour followed the defeat of Nader's third-party presidential bid that nevertheless had attracted record crowds in Oregon and across the country. The post-election trek drew its largest crowd in Portland in August 2001 when 7,500 people and a hundred sponsoring organizations gathered to 
hear Nader and other prominent progressives advocate for shopping local, supporting the labor movement, and building a new political movement to take back democracy. ${ }^{2}$

Labor progressives nationwide, including Portland Jobs with Justice executive director Margaret Butler, subsequently acknowledged the nature of the stiff challenges facing the labor movement following the 9-11 attacks that came within weeks of Nader's appearance in Oregon. Yet, Butler found new inspiration from the Powell's workers who she described as creating a bridge "between a lot of young activists and the labor movement," providing "hope for young workers who really need unions."3 Indeed, following the Powell's success, Local 5 took on new organizing campaigns in a city that experienced a growth of non-traditional labor organizing, including union drives among bike messengers, social service workers, and retail clerks by the Industrial Workers of the World (IWW), as well as immigrant day laborer organizing by the Voz Workers' Rights Educational Project. On another front of the progressive movement, activists in Portland adopted new networking and internet communication strategies to protest the Iraq War. In the immediate years following it formation, Local 5 bookstore workers publicly opposed both the war and the conservative policies of President George W. Bush.

The significance of the retail economic sector, including urban bookstores like Powell's, figured substantially in turn of the twenty-first century labor discontent. By 2015, retail employees would represent a growing 10 percent of the U.S. workforce and

\footnotetext{
2 "People Have the Power Tour: Portland, Ore.," 90.7 KBOO FM, KBOO Community Radio Archive, Portland, Ore., MD-163, August 4, 2001; "Democracy Rising 'People Have the Power Tour' 2001-2003," Democracy Rising, accessed January 17, 2017, http://www.gwu.edu/ action/2004/nader/naderrallies.html. 3 "Margaret Butler on the Founding of ILWU Local 5." YouTube video, 18:02, posted by "ilwulocalfive," October 24, 2012, https://youtu.be/4jeWAXojrug.
} 
account for fifteen million workers. ${ }^{4}$ While retail jobs have captured an increasingly larger proportion of the national employment market, employee income in this field has remained relatively stagnant and considerably lower than other categories of employment, creating what has been described as a precarious new population of working poor, or "precariat."

\section{Relevant Scholarship and Discourse}

Scholarship on the retail sector, those who labor within it, and their organizing efforts remains thin among historians and academics, outside a few notable exceptions and a surge of interest in recent years within the social sciences. Nonetheless, a discourse on retail work exists among a few historians, sociologists, political economists, and labor organizers on several themes, which frame this inquiry into ILWU Local 5. The first subject that provides the foundation to study the organization of retail booksellers at the turn of the twenty-first century is found within the dialogue among historians concerning the aspirations, politics, and agency of the working and middle classes. Herbert Gutman blazed the trail for U.S. labor historians with a collection of essays titled Work, Culture, and Society in Industrializing America (1976), which examined working-class culture, identity, and community in the nineteenth century. Gutman's positioning of laborers as subjects in their own historical and political development paralleled the writings of English historian E.P. Thompson. For these scholars, the "working class" existed as an ambiguous category with profound contradictions and variations, which compelled

\footnotetext{
${ }^{4}$ Kendra Coulter, Revolutionizing Retail: Workers, Political Action, and Social Change (New York: Palgrave Macmillan, 2014), 1; Industries at a Glance. March 4, 2016. accessed March 7, 2016. http://www.bls.gov/iag/tgs/iag44-45.htm.

${ }^{5}$ Coulter, Revolutionizing Retail, 10.
} 
Thompson to conclude in The Making of the English Working Class (1963) that rather than a static or uniform structure, class was a process of human relationships. While writing on an early surge in the labor movement in the 1890s, historian Alan Trachtenberg described the strike "as a working-class event in public life," an "expression of working-class life" with significant cultural expressions. ${ }^{6}$

A new examination of working-class culture, accordingly, accepts at its inception the understanding that its cultural character varies from decade to decade as well as among races, ethnicities, and gender. In Languages of Class: Studies in English Working Class History, 1832-1982 (1983) Gareth Stedman Jones elicited new questions regarding the formation of class. In contrast to Thompson, Jones challenged how social historians analyzed working-class culture and presumptions such scholars made concerning its revolutionary economic character. ${ }^{7}$ In "A New Agenda for American Labor History: A Gendered Analysis and the Question of Class" (1987), labor historian Alice KesslerHarris advanced the necessity of a critical examination of gender in "new" labor history. In this and subsequent writings, she pressed historians to integrate gender analysis within the study of work, class, and culture, a process which would decentralize the male workplace as the informative site of working-class identity, relationships, and actions. ${ }^{8}$

Another emphasis on worker agency came through the work of David Montgomery, a former machinist and Communist Party organizer. Montgomery advanced a New Labor History perspective on shop floor struggles that noted two

\footnotetext{
${ }^{6}$ Alan Trachtenberg, The Incorporation of America: Culture and Society in the Gilded Age (New York: Hill and Wang, 1982), 89.

${ }^{7}$ Gareth Stedman Jones, Languages of Class: Studies in English Working Class History, 1832-1982 (Cambridge: Cambridge University Press, 1983).

${ }^{8}$ Alice Kessler-Harris, Gendering Labor History (Chicago: University of Illinois Press, 2007), 149.
} 
significant trends in early labor history. First, he noticed the presence of "a collectivist counterculture" during the late nineteenth century that extended beyond a singular factory. In The Fall of the House of Labor (1988), Montgomery astutely recognized that the daily experiences of workers alone failed to entirely explain working-class consciousness. Rather, militant unionists committed to "the project" of class consciousness helped place the experiences of their fellow workers in context and further "endeavored to weld their workmates and neighbors into a self-aware and purposeful working class." ${ }^{\prime 9}$ Another study, Robert D. Johnston's The Radical Middle Class (2003), sought to rehabilitate the role of a radical and activist middling class within a series of progressive political activities and movements in early twentieth-century Portland. While Johnston's argument affirmed many of the conclusions of Montgomery, Gutman, and Kessler-Harris regarding the role of cross-class alliance, it emphasized the value of the middling class' leadership within social struggles. ${ }^{10}$

Discourse on the nature and evolution of corporate capitalism, both globally and within an urban context, represents another prominent theme within the scholarship on retail economic sector. Nelson Lichtenstein, the most prominent labor historian of the present day, has focused part of his scholarship on the realignment of power in the global economy from production firms to retailers, particularly Walmart. The retail sector, often given second-class importance by both financial magnets and unions for decades, emerged in the 1990s under the leadership of Walmart as a powerful interest and trendsetter in the global economy. Sam Walton's ability to synthesize technological

\footnotetext{
${ }^{9}$ Trachtenberg, The Incorporation of America, 93; Montgomery, Fall of the House of Labor, 2.

${ }^{10}$ Robert D. Johnston, The Radical Middle Class: Populist Democracy and the Questions of Capitalism in Progressive Era Portland, Oregon (Princeton, New Jersey: Princeton University Press, 2003).
} 
advances with borrowed merchandising strategies, plus strict labor relations, awarded him comparisons to John D. Rockefeller and allowed him to create one the nation's largest retailers with $\$ 43$ million dollars in annual sales by the time of his death in 1992. ${ }^{11}$ Walton's creative use of the Universal Product Code (UPC) allowed him to create digital warehouses of consumer shopping information, empowering Walmart to reverse the dominant power relationship previously held by suppliers and manufacturers. Lichtenstein illustrated how Sam Walton and his attorney John Tate perfected a union avoidance strategy that became standard procedure for employers seeking to smother labor organizing campaigns. Similar rationalization characterized bookstores described in journalism scholar Jon Bekken's critical "Feeding the Dinosaurs" (1997) and business historian Daniel M.G. Raff's glorification of the same process in "Superstores and the Evolution of Firm Capabilities in American Bookselling” (2000). ${ }^{12}$

Radical geographers have sought to illustrate how capitalism expands its markets by eliminating obstacles of time and space as it simultaneously creates distance between workers in order to thwart class solidarity. At the same time, the geographical approach has revealed the historical relationship between urban centers and unions, which have provided the latter with much of their political and economic power. Andrew Herod advocated for the creation of labor geography as a field of study in multiple articles, including "Workers, Space, and Labor Geography” (2003). Herod's argument, constructed upon the work of predecessors including Marxist geographer David Harvey

\footnotetext{
${ }^{11}$ Richard Vedder and Wendell Cox, The Wal-Mart Revolution: How Big-Box Stores Benefit Consumers, Workers, and the Economy (Washington, D.C.: American Enterprise Institute Press, 2006), 59.

${ }^{12}$ Jon Bekken, "Feeding the Dinosaurs: Economic Concentration in the Retail Book Industry," Publishing Research Quarterly (Winter 1997-1998): 3-26; Daniel M.G Raff, "Superstores and the Evolution of Firm Capabilities in American Bookselling," Strategic Management Journal 21 (2000): 1043-1059.
} 
and contemporaries such as Rebecca A. Johns, argued that workers exist as spatially embedded agents who can act in solidarity with each other across distances, build crossclass alliances, and contest capitalism's geographical fixes that prioritize capital accumulation over the wellbeing of workers. ${ }^{13}$ Greg LeRoy, advocate for the labor movement's involvement in urban development and author of "Smart Growth for Cities: It's a Union Thing" (2002), has recognized the historic relationship between capitalism and space. He concluded that urban sprawl has proved detrimental to existing unions in nine economic sectors and a contributing factor in the declining membership and influence of those unions. Thus, since unions exist historically as urban institutions, labor must assert its interests within city planning initiatives around the country.

A third theme attempts to understand the nature and conditions for workers' selforganization on the job, and includes contributions from both unionists and sociologists. Working-class intellectuals, those whose lived experience in workplaces and unions serve as the foundation of their critical and historical inquiry, provide an important perspective in understanding collective action in the workplace. Whereas New Labor Historians sought to focus on the common laborer of the nineteenth and early twentieth century, intellectuals including Martin Glaberman, Stan Weir, and Staughton Lynd challenged the prevailing assessments of the labor movement's rise to strength between the 1930s and 1950s by examining the actions of rank-and-file union organizers. Both Glaberman and Weir studied with Trinidadian Marxist intellectual C.L.R. James and participated in Trotskyist political organizations. Glaberman's Punching Out (2002) and Wartime Strikes

\footnotetext{
${ }^{13}$ Andrew Herod, "Workers, Space, and Labor Geography," International Labor and Working-Class History 64, Workers, Suburbs, and Labor Geography (Fall 2003): 117.
} 
(1980) both detail labor's dissatisfaction after the great wave of unionization in the 1930s, as well as the precept that worker action begets class consciousness and not vice versa. Glaberman concentrated his study on workers' culture of resistance, its often spontaneous transmission into action that contradicted conservative beliefs, and the role of working-class leaders, or a militant minority, who could initiate action and compel fellow workers to join them. ${ }^{14}$

Congruent with these elements of Glaberman's work is the recent publication Revolutionizing Retail (2014) by Kendra Coulter that structurally examines the recent organizing in the retail sector. Coulter asserted that a worker's emotions, a determinant for either submission or collective action, represented a "contested space" for managers, unions, and customers. ${ }^{15}$ In Coulter's advocacy of why retail matters and her investigation into recent worker and union initiatives to organize, she has applied an anthropological methodology accredited to fellow social scientist Linda Briskin known as "mapping," which traces the actions workers take to organize their fellow coworkers. ${ }^{16}$ Weir’s Singlejack Solidarity (2004) explained that “a workplace isn’t a collection of individuals so much as a collection of informal groups," and emphasized the role of these informal workgroups as the sparks and determinant forces for collective activity in the workplace. ${ }^{17}$ Lynd, although primarily an academic, has always remained close to rank-and-file activism and combined these relationships with historical study and oral

\footnotetext{
${ }^{14}$ Martin Glaberman, Wartime Strikes: The struggle against the no-strike pledge in the UAW during World War II (Detroit, Michigan: Bewick Editions, 1980), 125, 132-33.

${ }^{15}$ Coulter, Revolutionizing Retail 2014), 117.

${ }^{16}$ Coulter, Revolutionizing Retail 6; Coulter defines her mapping approach as, "both spatial and conceptual. It involves documenting and analyzing how workers' organizing takes shape in different places, often simultaneously. Connections, similarities, and differences are to be identified, and both the material and discursive dimensions of organizing are considered."

${ }^{17}$ Stan Weir, Singlejack Solidarity (Minneapolis, Minnesota: University of Minnesota Press, 2004), 250.
} 
history to author Solidarity Unionism (1992). Lynd terms the participatory qualities of the labor activism that spurred the Congress of Industrial Organizations (CIO) as "solidarity unionism" and juxtaposed it with the centralized and sectional "business unionism" of the contemporary labor movement.

English sociologist David Wright, whose research examines the connections between consumption and work within cultural arenas, published a study examining the relationship between bookstore workers and the objects they sell that he titled "Commodifying Respectability: Distinctions at Work in the Bookshop" (2005). Wright's arguments have implications for further research into the subsector, particularly for how some bookstore workers' pre-existing emotional attachment to books as culturally imperative objects of self-development could influence their decisions to challenge working conditions through collective activity. Wright concluded that a clerk's attachment to books serves as a "resource" for workers to shield themselves from the alienation inherent within the service workplace." 18

Another theme, primarily addressed by economists and sociologists, is the evolution of the labor process within modern capitalism and its contributions to the mental and emotional alienation workers experience. This theme owes much to Harry Braverman's Labor and Monopoly Capital (1974), which has influenced generations of social scientists because of how it revitalized Marx's argument regarding the "progressive alienation of the process of production from the worker" under capitalist

\footnotetext{
${ }^{18}$ David Wright, "Commodifying Respectability: Distinctions at Work in the Bookshop," Journal of Consumer Culture 5 (3): 311.
} 
management. ${ }^{19}$ Braverman, a former metal worker and a Marxist political economist, argued that shifts in social relationships corresponded to changes made to the modes of production. He detailed how employers became increasingly successful at incorporating the middle class and capturing, dividing, managing, and automating a laborer's skill. Braverman's insight on retail and service work is particularly pertinent. For instance, he observed in the 1970s how the utilization of Universal Product Codes (UPC) were beginning to empower businesses with tremendous amounts of new information that made consumer purchasing patterns predictable, contributing to the rise of "logistics" as a field of business management. Conversely, the UPC innovation allowed employers to decrease labor hours. Braverman believed that the UPC led to the commodification of all goods and services, and forewarned before other scholars that a "revolution is now being prepared which will make of retail workers, by and large, something closer to factory operatives than anyone had ever imagined possible."20

A corollary theme to the alienation of labor is the historically antagonistic and evolving relationship between management and employees. David R. Roediger, prominent historian of race and culture in the United States, made significant contributions to labor history in his study of time and management. While Roediger demonstrated the important struggle over the duration of the work day in Our Own Time (1989), in The Production of Difference (2012) he traced the origins and historic role of management theory. Sociologists have noted how retail management has increased its

\footnotetext{
${ }^{19}$ Emphasis by Braverman. Harry Braverman, Labor and Monopoly Capital: The Degradation of Work in the Twentieth Century (New York: Monthly Review Press, 1974), 58.

${ }^{20}$ Braverman, Labor and Monopoly Capital, 371.
} 
efforts to control the emotions of retail service workers, which has significantly affected workers' internal psyche and their capacity to collectively resist.

Arlie Russell Hochschild's concept of “emotional labor," first developed in her study of flight attendants in The Managed Heart (1983), has become a required framework from which to study management and employees within the service sector. ${ }^{21}$ Hochschild, like Braverman before her, rehabilitated Marx's theory of alienation and applied it to the growing number of predominantly women service workers in the modern Western economy. Hochschild, greatly influenced by the writings of C. Wright Mills, observed how service economy employers incorporated the employee's personality and emotional expression into workplace behavior, a process Hochschild termed "the transmutation" of emotion from the private sphere into the waged economy. While this process provided the employer with greater control and competitive advantage in the service economy, the commodification of emotion through the coercive corporate management of feelings led to a worker's estrangement: the division and tension between a person's "real" self and their employee, or "on stage," self. ${ }^{22}$

At the time of her writing, Hochschild concluded that emotional labor predominantly pertained to a set of feminine middle-class jobs. Since then, the recent surge in scholarship on the retail sector, such as the collections of articles in Working in the Service Society (1996) by Cameron Lynne Macdonald and Carmen Sirianni, and Retail Work (2011) by Irena Grugulis and Öbdül Bozkurt, have revealed emotional

\footnotetext{
${ }^{21}$ Hochschild defined emotional labor as "the management of feeling to create a publicly observable facial and bodily display; emotional labor is sold for a wage and therefore has exchange value." Arlie Russell Hochschild, The Managed Heart: Commercialization of Human Feeling (Berkeley, Calif.: University of California Press, 1983), 7.

${ }^{22}$ Hochschild, The Managed Heart, 19.
} 
labor's ubiquitous presence throughout the retail sector. Macdonald and Sirianni emphasized how the historically low rate of unionization among front-line service workers engaged in face-to-face work, termed the "emotional proletariat," should not be misconstrued as either a sign of employee contentment or passivity. Rather, changes to technology and labor processes have altered how workers display dissatisfaction with management, but that resistance continues through everyday methods and tactics, which are often misunderstood or entirely ignored by the institutional labor movement. ${ }^{23}$

Grugulis and Bozkurt's collection of articles from social scientists reiterated Braverman and Hochschild's conclusions regarding the deskilling of labor through management's application of technology. As a result, retail managers hire for "soft skills," qualities related to petit-bourgeois sociability and aesthetic, conferring skill upon the presentation of "middle classness." ${ }^{24}$ Cameron Lynne Macdonald and Carmen Sirianni's collection of articles, titled Working in the Service Society (1996), carried on the research of Braverman and Hochschild, as well as complements Roediger's historical inquiry with contemporary analysis.

The historiography of the service economy remains considerably thin, despite several recent contributions. Nonetheless, Dorothy Sue Cobble's Dishing It Out: Waitresses and Their Unions in the Twentieth Century (1991) acts as model for how to synthesize institutional labor history with the approaches of Gutman and Kessler-Harris, by applying historical inquiry to service work. In this work, Cobble illustrated the interrelationship of gender, work, and skill classification by documenting the emotional

\footnotetext{
${ }^{23}$ Cameron Lynne Macdonald and Carmen Sirianni, ed., Working in the Service Society (Philadelphia, Penn.: Temple University Press, 1996), 3.

${ }^{24}$ Irena Grugulis and Öbdül Bozkurt, ed. Retail Work (New York: Palgrave Macmillan, 201), 298-99.
} 
labor of waitresses. "Workplace struggle," explained Cobble, determined "the achievement of skill status," and that waitresses elevated their emotional labor to the status level of a craft through unionization. Cobble's research into what she terms as "occupational unionism" also included a critical analysis of the functional use of solidarity within the broader labor movement and the triangular relationship that exists between management, workers, and customers. ${ }^{25}$

\section{The Historical Imperative and the Sources for this Study}

The absence of previous scholarship on the Powell's Books union campaign, as well as the recent upsurge and interest into workers' organization within the retail sector of the economy, has created an imperative for historical inquiry. The lack of scholarship is emblematic of the field of labor history because of the historically low level of service sector organizing in the United States. Previous attention to the Powell's union remains limited to a published interview with a Local 5 member for the ILWU and an equally brief account that focused on the campaign's strategy for Labor Notes, an independent publisher reporting on the labor movement since 1979. Yet, a historical inquiry into the Powell's union campaign is more appropriate now than ever before because of the continued centralization and growth of the retail sector and the recent surge in nontraditional organizing by mainstream unions as demonstrated by the Our Walmart and Fight for $\$ 15$ movements. As a case study, this thesis seeks a historical understanding of the under-investigated field of retail labor organizing within the subsector of bookselling, under the premise that although most union authorization and contract campaigns share

${ }^{25}$ Dorothy Sue Cobble, Dishing It Out: Waitresses and Their Unions in the Twentieth Century (Chicago: University of Illinois Press, 1991), 137. 
many similarities, there exists creative initiatives and individuals awaiting to be resurfaced through the ephemera found in union archives and the oral histories of union members.

This work examines the aspirations, tactics, and context for the Powell's Books workers' union drive between 1998 and 2001. It considers two quotes reflecting on the union's experience by Powell's worker and organizer Mary Winzig. "Powell's was unique," Peter Olney, former Organizing Director for the ILWU, remembered Winzig saying, "but every organizing drive is unique, but every organizing drive is the same." 26 This thesis investigates what made the Powell's campaign unique among other union drives and why it was successful within an economic sector so predominantly unorganized. Was the success an outgrowth of the broader social movement unfolding at that time or the result of a momentarily resurgent labor movement? "You don't expect a group of middle-class white kids to organize a union, but that's what we did," Winzig observed. ${ }^{27}$ Does the Powell's union challenge or reinforce preconceived notions of the labor movement? This work addresses these questions and, more broadly, seeks to replicate the narrative response of bookstore workers to the increased centralization and rationalization of their labor during a tumultuous three-year cross-section of history within the retail sector.

The primary sources used to examine the history of the ILWU Local 5 and the Powell's Books' union campaign divide into three categories: oral histories, archival

\footnotetext{
${ }^{26}$ Peter Olney, interviewed by Harvey Schwartz, Local 5 Oral History Project, Anne Rand Library, International Longshore and Warehouse Union, San Francisco, Calif., June 3, 2002, 13.

${ }^{27}$ Jane Slaughter ed., A Troublemaker's Handbook 2: How to Fight Back Where You Work and Win! (Detroit: Labor Notes Books, 2005), 220.
} 
documents, and press coverage. The ILWU Local 5 Oral History Project serves as a valuable source to evaluate the union's early years because of its selection of participants and the context during which the interviews occurred. ILWU historians Edward Beechert and Harvey Schwartz conducted the project by individually interviewing fourteen participants in the local's recognition campaign and first contract. The collection of narrators included nine Powell's workers, one former worker, and four members of the ILWU's international staff, which included the President and Organizing Director. While Beechert and Schwartz's selection process for Powell's employees appears relational and not systematic, those interviewed represented active members of the union who served on its organizing committee, bargaining committee, or as a steward during either the union drive or at the time of the interviews. The exchanges occurred between April 2001 and September 2002 during the middle of the union's first contract cycle and captured the workers' memories, assessments, and aspirations at that time. Only Schwartz's interview with Mary Winzig has received academic citation or publication, found only in his Solidarity Stories: An Oral History of the ILWU (2009). Thus, this thesis brings the narratives of union bookstore workers into the historical dialogue for the first time.

Although the Beechert and Schwartz's institutional oral history project limited its focus on a specific series of events within a four-year period, it is a rich resource because of the trust, community, and institutional knowledge the interviewers and participants shared. Beechert, who interviewed nine workers and one staff member in Portland, maintained a consistent line of inquiry for each worker that included three categories: 1) the worker's job and initial response to the union, 2) the worker's participation in the union and what tactics were successful or failed, and 3) how is the union functioning 
currently and what issues are of greatest concern. While pursuing these questions, Beechert also sought out the workers' opinions of management and bookstore owner Michael Powell. Schwartz interviewed three staff members in San Francisco about the international union's internal politics, organizing strategy, and direct participation in the Powell's campaign, as well as what factors positioned the ILWU as the union of choice for the bookstore's workforce. Together, the interviews allow the narrators to document and assess the effectiveness of both the union's and the company's tactics during the organizing drive.

The ILWU Local 5 archive serves as the thesis' second group of primary sources and proved vital to establishing both the institutional account of the local's history and the dialogue among workers regarding the union. The local maintains a paper archive of communications and activities during the union's first five years, which covers the recognition campaign, contract campaign, and post-contract union building phase. In addition to providing a timeline of events, a record of union activists, and correspondences with community organizations, the Local 5 archive preserved the political culture of the union through its collection of writings and images created by supporters, opponents, and undecided workers. The cache of documents includes a small collection of the anti-union materials circulated by individual and semi-organized groups of Powell's workers opposed to Local 5, as well communications from management to workers regarding the union's involvement in the store. These documents articulate the content and context of the dialogue workers engaged in about unionization. Additional cultural artifacts of the union movement include a collection of button and sticker slogans, songs and poems, as well as letters and cartoons. Local 5's three membership 
surveys captured a portion of the workplace's demographic and priorities during the contract negotiations. Although not scientifically sampled, these internal surveys represent a useful resource to measure the membership engagement with the union and the contract negotiations. Similar to the oral history collection, these documents have not been used previous to this thesis.

The local press' reporting and editorial debate regarding the Powell's union campaign serves as the third group of primary sources. Few other union recognition campaigns in Portland during the 1990s received as much attention from local press and the public as the Powell's workers' campaign. The public opinion battle over the union's efforts had profound implications on the contest and generally was revealed in the press' news coverage, editorials, and letters-to-the-editors. The business, independent, and special interest press all paid close attention to the campaign, which challenged Michael Powell's credibility as a high profile liberal business leader. The Oregonian, Willamette Week, Portland Business Journal, Northwest Labor Press and The Portland Alliance covered the workers effort to organize at one of the nation's leading independent bookstores; the struggle also made the pages of the LA Times and The Nation. Local television and radio stations, particularly KBOO FM Portland, maintained an interest in the events, particularly as large, traffic-stopping, demonstrations appeared in front of the store in the spring of 2000.

The thesis follows a chronological timeline that traces the first three years of the Powell's Books union, which began in 1998 when workers formed an organizing campaign, ends in 2001 with the ILWU Local 5's first year under contract, and is punctuated by the 2000 May Day rally. The work contains five chapters and a 
Conclusion. Chapter One addresses the history of the labor movement with attention to the retail economic sector, the efforts to resuscitate the labor movement in the 1990s, and Portland's labor history. Chapter Two details the evolution of the American bookstore since 1950 and presents a history of bookselling in Portland with focus on Powell's Books. Furthermore, the chapter traces booksellers' resistance to changing job conditions and their cultural position within society. A survey of early efforts to organize the workforce at Powell's precedes an investigation of the 1998-1999 ILWU's organizing and recognition campaign found in Chapter Three.

Chapter Four explores the contract campaign, which reached a stalemate in the spring of 2000, and Chapter Five examines the series of events that occurred during May and June 2000 that precipitated a three-year agreement signed in September 2000. Additionally, the last chapter addresses the continued tension between management and the union during the first year of the contract and Local 5's efforts to expand its model of unionization into other workplaces. Finally, the Conclusion assesses the significance of the Powell's union campaign and attempts to deduce conclusions regarding its unlikely success, its choice of tactics, and unexpected alliances. From there, the Conclusion suggests further areas of historical inquiry that might broaden the understanding of Portland's labor history, as well as the fate bookselling and retail union organizing efforts. 


\section{Chapter 1}

\section{Landscape of Labor}

After years of accommodation or submission, organized labor across multiple continents responded to the neoliberal challenge with an unexpected strike wave that began in the mid-1990s and carried through to the end of the century. Kim Moody, author of Workers in a Lean World (1997), counted twenty-two mass political strikes by workers in twenty countries between January 1994 and February 1997; including French strikes opposed to the Plan Juppé austerity plan, Canadian "Days of Action" against free trade policies, a South Korean general strike in response to the elimination of labor laws, and international solidarity actions for locked out British dockworkers. ${ }^{28}$ Moody observed in these strikes a tendency for established unions to break with national political parties, as well to broaden their scope societally and globally in a strategy he termed "social movement unionism. ${ }^{29}$ Labor protest also translated into enthusiasm for new organizing in North America. The Canadian labor movement found hope for its future when in 1997 retail workers successfully unionized at a Walmart in Windsor and, in the same year, the Canadian Auto Workers organized the first union at a Starbucks. ${ }^{30}$

\footnotetext{
${ }^{28}$ Kim Moody, Workers in a Lean World: Unions in the International Economy (New York: Verso, 1997), 9-31.

Kim Moody, "Austerity Fuels Mass Strikes Around the World," Labor Notes, April 1997, 1.

${ }^{29}$ Moody, Workers in a Lean World, 4-5.

30 "Starbucks Workers Stage UnStrike," Labor Notes, November 1999, 2.; "News Watch," Labor Notes, September 1997, 4.; Bruce Constantineau, "Last B.C. Starbucks outlets cut ties to union," Vancouver Sun, April 28, 2007. Starbucks' first opened in Canada in 1987, while Walmart arrived in 1994 following the acquisition of 122 Woolco stores that were reopened as Walmarts. The Canadian Auto Workers organized twelve Starbucks locations in 1997 with 150 workers only to have the baristas decertify all the union shops by 2007. The United Steelworkers helped organize a Walmart in Windsor, Canada in 1997 but left in 2000 after failed contract negotiations.
} 


\section{Organized Labor in the United States Awakens in the 1990s}

Modern labor history in the United States has been framed by the National Labor Relations Act (NLRA) (1935), which ushered in the era of legally protected, productionhalting strikes during which unions organized 21 million workers by $1979 .{ }^{31}$ But, during the forty-five years following the passage of the NLRA the federal government and union leadership bargained away many of the extralegal freedoms of workers, such as the right to strike during the length of contract. These two growing tendencies collided with a detrimental effect for organized labor in the 1980s. Labor historians point to President Ronald Reagan's replacement of striking air traffic controllers in 1981 as a sign of a new era during which private corporations, emboldened in part by the president's actions, aggressively pushed back upon unions. Even where organized labor responded with militancy, such as during the 1985 Hormel strike, unions proved incapable of slowing the tide of setbacks and defeats, which included not simply dollars-and-cents measures but also the reduction of union power in determining workplace conditions.

The labor movement demonstrated signs of a renaissance in the 1990s as rankand-file voices on the margins and a new cohort of progressive union leaders began to break with the forty-year course steadied for it by organized labor's established leadership. A growing number of disaffected unions within the AFL-CIO questioned the leadership of President Lane Kirkland and his passivity towards job killing trade deals and his failure to initiate organizing in new economic sectors. Those concerned about the future of the labor movement and the fate of American workers in the twenty-first

${ }^{31}$ Gerald Mayer, Union Membership Trends in the United States (Washington, D.C.: Congressional Research Service, 2004), Summary. 
century pointed to ominous signs in numerous indicators. As the number of U.S. union members declined sharply from its 1954 historic high of 28.3 percent of employed workers to 13.1 percent in 1994, observers also noted the growing apathy among union members. ${ }^{32}$ That same year, unions lost 54 percent of union representation elections administered by the National Labor Relations Board (NLRB). ${ }^{33}$ Conservative economists considered these facts, coupled with the declining number of work stoppages, as evidence that the relevancy of unions to American workers was a thing of the past. Indeed, between 1979 -Kirkland's first year as president- and 1993, both the number of work stoppages and the number of workers involved in such actions declined by over 80 percent. $^{34}$

Progressive unionists argued that the AFL-CIO's conservative and narrow organizing strategy, along with an increasingly detrimental relationship with the Democratic Party, caused the dramatic deterioration of its bargaining power and public support. Indeed, as rank-and-file workers experienced the harshest effects of growing attacks on the labor movement, union members in multiple sectors during the 1990s increasingly scrutinized their union officials. Member activists scrutinized their leadership's collective bargaining and organizing records, six figure salaries, and commitment to internal democracy. Under the leadership of Ron Carey from the Teamsters for a Democratic Union (TDU), the International Brotherhood of Teamsters

\footnotetext{
${ }^{32}$ Mayer, Union Membership Trends.

${ }^{33}$ National Labor Relations Board. Fifty-Ninth Annual Report of the National Labor Relations Board for the Fiscal Year Ended September 30, 1994 (Washington, D.C.: U.S. Government Printing Office, 2015), 140, accessed January 16, 2017, https://www.nlrb.gov/sites/default/files/attachments/basic-page/node1677/nlrb1994.pdf.

${ }^{34}$ U.S. Bureau of Labor Statistics, "Table 1. Work Stoppages Involving 1,000 or More Workers, $1947-$ 2015," Economic News Release (Washington, D.C.: U.S. Department of Labor, last modified February 10, 2016), accessed May 27, 2016, http://www.bls.gov/news.release/wkstp.t01.htm.
} 
were at the forefront of the labor movement in the 1990s as a union successfully captured by rank-and-file reformers and committed to organizing. Conversely, under the twenty plus years of Edward Hanley's leadership, the Hotel Employees and Restaurant Employees International Union (HERE) lost its significant influence within the rapidly growing hospitality sector. Although a Department of Justice investigation in 1995 found convincing evidence of corruption and led to Hanley's forced retirement, rank-and-file reformers in Chicago's Local 1 reported that the Hanley family maintained influence over the local's new leadership in the years that followed. ${ }^{35}$

In the AFL-CIO's first contested election and amid great expectations, a coalition of dissident unions leaders rode the tide of reformism that flowed from the margins of the labor movement. In 1995, the "New Voice" leadership slate of John Sweeney of the Service Employees International Union (SEIU), Richard Trumpka of the United Mine Workers of America (UMW), and Linda Chavez-Thompson of the American Federation of State, County, and Municipal Employees (AFSCME) defeated Kirkland and his followers. The new administration made their ambitions clear from the beginning, stating their goal to "renew the labor movement" by activating union members, exciting unorganized workers to join unions, and opening doors to new allies. ${ }^{36}$ Sweeney described the election as "a moment of hope and promise for the future" and his administration carried this optimism into institutional reforms. ${ }^{37}$

\footnotetext{
${ }^{35}$ Carl Biers, "Hotel Employees President 'Retires' Under Pressure," Labor Notes, July 1998, 1.; "News Watch," Labor Notes, October 1999, 4.

${ }^{36}$ Gregory Mantsios, ed. A New Labor Movement for the New Century (New York: Monthly Review Press, 1998), 329.

${ }^{37}$ Stuart Silverstein, "Sweeney, a 'New Voice,' Is Voted AFL-CIO Chief," Los Angeles Times, October. 26, 1996, accessed April 11, 2016. http://articles.latimes.com/1995-10-26/business/fi-61364_1_laborfederation.
} 
The New Voice slate represented a cultural shift in the U.S. labor movement whose leaders began restructuring the AFL-CIO from the top down in an effort to make the greatest amount of change in the least amount of time. Although the new leadership recognized local unions and Central Labor Councils as best positioned to implement its new organizing initiative across the country, top officials anticipated regional opposition to financial reforms and diversity directives from above. Thus, the Sweeney administration sought to create a new standard for investing in organizing by devoting 30 percent of its budget to new campaigns with the hope of setting an example for locals. In order to work around opposition from the locals, the leadership increased the size and the responsibility of the Federation's staff. While the power shift towards the international and its staff prompted critique from some unionists and the secession of several affiliate unions beginning in 2000, observers including author and United Auto Workers (UAW) activist Mike Parker noted that the previous norm of "denouncing internal critics as destroyers of unity and agents of the enemy" had waned with the new leadership. ${ }^{38}$ Sweeney demonstrated this cultural shift by writing the afterword to an anthology of essays entitled A New Labor Movement for the New Century (1998), describing it as a "valuable contribution" to the labor movement's "new spirit of open debate and aggressive action." ${ }^{39}$ Tellingly, four of the authors and union activists received staff positions in Sweeney's administration.

\footnotetext{
${ }^{38}$ Mike Parker, "In the New AFL-CIO: Open Talk about Labor's Strategy," Labor Notes, December 1998, 10.; Steve Early, "New Organizing Should be Member-Based," Labor Notes, April 1996, 12.

${ }^{39}$ Gregory Mantsios, ed. A New Labor Movement for the New Century (New York: Monthly Review Press, 1998), 327.
} 
Between 1995 and 1997, New Voice funneled increasingly more resources to new diversity initiatives, organizing efforts, and political tactics than ever before in the AFLCIO's history. In an attempt to reflect the changing demographic and identity of the working class, under Sweeney's leadership the AFL-CIO reversed its opposition towards immigration to support citizenship for undocumented workers and welcomed the affiliation of Pride at Work, a LGBT labor organization. Under the banner of "Organizing for Change, Changing to Organize," the new leadership invested over $\$ 30$ million dollars to new organizing initiatives, including the Union Summer program that trained college students to organize unions in between their academic sessions. The New Voice slate hoped to utilize Central Labor Councils in cities across the country to conduct its Union Cities program, which sought to increase labor standards through local legislation. ${ }^{40}$ Furthermore, under Sweeney's leadership, the AFL-CIO entered digital space by launching its first website in 1996. However, while union activists began utilizing the internet to create horizontal communication structures through such tool as online discussion forums, the AFL-CIO's website presented a top down flow of information. ${ }^{41}$

Along the West Coast during the 1990s, the International Longshore and Warehouse Union (ILWU) helped lead labor's resurgence by committing greater resources and energy to organizing. The union, established following the 1934 Maritime Strike when several West Coast locals split from the East Coast based International Longshore Association (ILA), did not experience the same depth of struggle over the

\footnotetext{
${ }^{40}$ Russ Davis, “AFL-CIO Unveils Program to Revitalize Labor Movement,” Labor Notes, March 1997, 14. ${ }^{41}$ Brandon Weber and Alan Jacobson, "Organizing and Information Gathering via the World Wide Web," Labor Notes, July 1997, 12: Teamsters for a Democratic Union (TDU) activists launched an independent website ahead of the Teamster's international convention and officer elections to rapidly relay information to members.
} 
cultural shift brought on by the changes within the AFL-CIO leadership that the rest of the labor movement experienced. Arguably, ILWU's history of militant organizing and position on civil rights kept the union outward facing for periods of time when many other unions gazed inward. In fact, the ILWU had begun to turn its attention to new organizing in 1991, revamping a long neglected organizing program under the leadership of new president Dave Arian. At the union's next convention three years later, delegates passed a resolution forwarded by Arian that committed 30 percent of the international's budget to organizing. ${ }^{42}$ Yet, disagreement regarding the effectiveness of the campaign led to a challenge of leadership. In the July elections, Arian lost to Vice-President Brian McWilliams, who explained his victory as a return to the union's principles in his first report as president: "The membership perceived that we were making a transition from a rank-and-file union to a top-down one; a change that was unacceptable."43 Beyond the commitment to organize more, the question for the ILWU remained where to organize and how to compel locals to financially support new campaigns?

During the Arian leadership, the international created a Regional Organizing Committee for the Columbia River region and made modest gains in adding new bargaining units into Local 8 . However, these gains proved temporary as servicing these new workers in regions as far away as Idaho proved too difficult for the current union's structure. McWilliams, who began working on the waterfront in 1967, also ambitiously sought to extend organizing into the growing West Coast warehouse sector, but imagined new targets, as well. "There were no organized hotels in San Diego and there was only

\footnotetext{
42 “Convention Delegates Make Organizing, Education Priorities," The Dispatcher, May 16, 1994, 1. ${ }^{43}$ Brian McWilliams, "Put good of the union first to move forward," President's Report, The Dispatcher, August 29, 1994, 2.
} 
one organized hotel in Portland," he later recalled. Inspired by the hundreds of hotel workers in Hawaii already organized into the ILWU, McWilliams differentiated his approach from his predecessors by targeting the service industry and prioritizing the creation of new non-longshore locals. McWilliams voiced his belief that unionized longshore workers possessed a great degree of privilege among the working class, and that supporting workers' efforts to organize was the optimum way to "leverage that power" the ILWU had amassed. ${ }^{44}$

During the 1990s, several unions attempted to revitalize the work stoppage as a winning tactic in labor conflicts, using both prolonged economic strikes and one-day publicity walkouts. In Decatur, Illinois in 1993 following years of stalled contract negotiations over union concessions and an effort by workers to slow production, management at A.S. Stanley (a grain processing plant purchased by a multinational corporation Tate \& Lyle in 1988) locked out its employees. While workers at Decatur's Caterpillar and Firestone Tire and Rubber Co. plants joined the grain workers on strike in the summer of 1994 and led several high profile marches and rallies, A.E. Stanley's use of replacement workers, court injunctions, and collaboration with police forced the striking workers to accept unprecedented contract concessions. ${ }^{45}$ On July 13, 1995, 2,500 workers at the Detroit News and Detroit Free Press struck after management instituted new work rules following stalled contract negotiations. Though the strike resulted in a loss of over $\$ 100$ million for the papers, owned by media conglomerates Gannett and

\footnotetext{
${ }^{44}$ Brian McWilliams, interviewed by Harvey Schwartz, Local 5 Oral History Project, ILWU Archive, San Francisco, Calif., July 19, 2002, 4-5.

${ }^{45}$ Moody, Workers in a Lean World, 24-28; David Moberg, "Labor Intensive," Chicago Tribune, November 11, 1994, accessed April 11, 2016, http://articles.chicagotribune.com/1994-1111/features/9411110077_1_big-union-industrial-workers -union-buster.
} 
Knight-Ridder, management responded by investing in replacement workers and security, waiting nineteen months for the unions to surrender. ${ }^{46}$ Despite repeated appeals in July and December 1996 for a labor march in Detroit from activists, including the Action Coalition of Strikers and Supporters, it took the AFL-CIO's newly elected Sweeney administration until February (the same month the union was forced to concede) to call for a national day of action. ${ }^{47}$

Labor's defeats in Decatur and Detroit only emphasized the previously stated recommendations of progressive and radical unionists that the AFL-CIO unions needed to dramatically change how they organized and responded to challenges from large corporations. Observers, including Martin Glaberman and Kim Moody, noticed signs of promise in the dozen of localized strikes led by the UAW demanding an increase in hiring. ${ }^{48}$ The Justice for Janitors campaign in Los Angeles acted as further inspiration as SEIU innovatively organized a predominantly immigrant workforce, scattered throughout numerous downtown job sites and employed by several different contractors. Janitors working in Century City high-rises struck in 1990 and won recognition of their union, overcoming violent confrontations with the police. A decade of continued organizing led to a victorious three-week strike in 2000, expanding the union's reach even wider throughout the city. ${ }^{49}$ The successes of the Justice for Janitors campaign in Los Angeles

\footnotetext{
46 "Bitter Battle: The Detroit Newspaper Strike," Revolutionary Worker, July 13, 1997, accessed April 11, 2016, http://revcom.us/a/v19/910-19/915/detstr.htm.

${ }^{47}$ Kate DeSmit, "Newspaper Strikers Renew Call for National March on Detroit," Labor Notes, January 1997, 3. Shelley Ettinger, "100,000 March in Detroit," Workers World, July 3, 1997, accessed May 26, 2016, http://www.workers.org/ww/1997/detroit0703.html.

${ }^{48}$ Martin Glaberman, Punching Out and Other Writings. Edited by Staughton Lynd (Chicago: Charles H. Kerr Publishing Company, 2002), 74.; Moody, Workers in a Lean World, 30-31.

${ }^{49}$ Harold Meyerson, "The Red Sea," LA Weekly, April 26, 2000, accessed April 11, 2016, http://www.laweekly.com/news/the-red-sea-2131956.
} 
propelled it to a national level as SEIU locals in other cities copied its organizing model. In the nineties, Portland's Local 49 organized a downtown rally that featured a speech by, then SEIU president, John Sweeney as well as street rallies for displaced union janitors. ${ }^{50}$

On the national scale, the sixteen-day United Parcel Services (UPS) strike in the summer of 1997 by Teamsters translated the renewed spirit of the labor movement into action on the public stage. The strike crippled UPS's operations, responsible for delivering 80 percent of the nation's packages including those of retailers, such as Powell's Books, and amounted to a loss of $\$ 600$ million dollars for UPS. Despite modest consumer and small business dissatisfaction, the union's demand for ten thousand new full-time positions won the sympathy of the public who had alternative shipping options to choose from during the strike. ${ }^{51}$ Although President Bill Clinton had ordered American Airlines pilots to end their strike earlier in the year and intervened in the Major League Baseball players' 1994 season-halting work stoppage, Clinton denied UPS's appeals to use his authority to end the strike. In Oregon, the walkout involved 2,700 UPS Teamsters from the Joint Council of Teamsters 37 based in Portland, whose president reported the union members were " $100 \%$ solid on the picket lines." 52 Even workers interviewed by the Oregonian who expressed disagreement at the union's decision to strike refused to cross picket lines. ${ }^{53}$ Portland-area Teamsters received extensive support from local unions including the Machinist Union District Lodge 24, which refused to cross UPS picket lines. Through a long-practiced tradition of solidarity, ILWU Local 8 provided work to

\footnotetext{
50 "March for Justice," Northwest Labor Press, October 2, 1992, 13; "Portland Janitors Take to Street for Justice," Northwest Labor Press, March 20, 1998.

${ }^{51}$ Jim West, "Big Win at UPS!" Labor Notes, September 1997, 1.

52 "Striking Teamsters Say Part Time America Won't Work" Northwest Labor Press, August 15, 1997.

${ }^{53}$ Lisa Levenson, "UPS-Teamsters Strike May Become a Long Haul," Oregonian, August 12, 1997.
} 
striking Teamsters in need. Additionally, Oregon Public Employees Union (OPEU)

members at Oregon State University resisted pressure from the administration to complete deliveries typically done by UPS workers. ${ }^{54}$

In an article titled "UPS Strike Makes New Labor History," written as the work stoppage unfolded, labor historian Nelson Lichtenstein predicted the Teamsters' victory would put an end to idea that a strike was "synonymous with labor's defeat and demoralization.” These several examples of renewed militancy within organized labor did not guarantee future success, nor were the defeats entirely fruitless. Ultimately, both the victories and the defeats in the strikes of the 1990s highlighted for labor the need to work around the nation's restrictive labor laws, organize among the growing service sector, and build strong community-labor coalitions.

\section{New Political Efforts}

The revitalization of the labor movement in the 1990s included several unions ambitiously organizing the formation of a new national political party. Following decades of preparation and organization by a loose coalition known as Labor Party Advocates, over 1,300 delegates representing unions from around the country converged in Cleveland, Ohio to found the Labor Party of America in June 1996. The ILWU along with the United Electrical Workers (UW) and the Oil, Chemical, and Atomic Workers Union (OCAW) were among the initial endorsing unions of the new political party. The longshoremen advocated at the convention for the ability to run local candidates, but uncertainty and disagreement among delegates regarding whether to formally break with the Democratic Party led to the Labor Party's decision not to run or endorse candidates.

54 "Victory at UPS," Northwest Labor Press, September 5, 1997. 
Leading co-founder, Tony Mazzocchi, believed that "the silliest thing in the world would be to get involved in local elections." Citing the political right's success in shaping the nation's political discussion, he questioned the logic of running candidates outside of the two dominant parties on the local level because "[the] way this nation is set up, what the hell can you do in a local office except frustrate all your constituents?"55

Despite considerable enthusiasm among unions and their membership for the Labor Party, Sweeney and the AFL-CIO withheld a full endorsement. Nevertheless, calls for a labor party persisted even among Democratic Party politicians with union backgrounds. Former firefighter and Oregon state legislator Randy Leonard told the state's 1999 AFL-CIO convention that powerful interests within the Democratic Party "disdain those of us who represent working-class Oregonians" and suggested the time may be ripe for a labor party. ${ }^{56}$ Ultimately, the Labor Party's relevance slowly declined over the next decade as the Working Families Party and later the Green Party gathered increasingly more adherents from those seeking a progressive third force.

\section{Social Unionism and Alternatives to Collective Bargaining}

Beginning in the 1970s, workers' rights activists experimented with new tactics and forms of organization to compensate for the nation's most influential unions inability to respond to frequent factory closures or organize amongst marginalized workers in immigrant and minority communities. By the 1990s, these efforts, often termed "social

\footnotetext{
55 Jane Slaughter, "Overflow Crowd Expected at Labor Party's Founding Convention," Labor Notes, June 1996, 12; Jane Slaughter, "History in the Making: Labor Party," Labor Party, July 1996, 8; Kim Moody, "Labor Party's Convention Clears the Way to Run Candidates, Sets Health Care Campaign," Labor Notes, December 1998, 3.

56 "Leonard Says Time Might be Ripe for a Democratic Labor Party," Northwest Labor Press, October 1, 1999.
} 
unionism" because of their emphasis on strong community support, achieved noteworthy victories through worker centers and living wage initiatives. Jobs with Justice, founded in 1987 with assistance from Communications Workers of America (CWA) President Larry Cohen, became the most prominent new national organization that sought to link struggles of health care, immigration, and global justice to workers' bargaining rights ${ }^{57}$ Although initially the AFL-CIO under Kirkland's leadership reacted ambivalently to the new community-labor alliance, relations improved under Sweeney's leadership. By 1996, the AFL-CIO’s Organizing Director Richard Bessinger described the coalition's thirty local chapters, built upon the principles of direct action and a shared leadership with local unions and social justice organizations, as "the conscience of the labor movement. ${ }^{\prime 58}$ Through civil disobedience and its use of Workers' Rights Boards (a community initiative that could respond quickly and apply public pressure upon illegal union busting activity), Jobs with Justice locals, including the Portland chapter, challenged the power of the National Labor Relations Board for responding slowly to employer Unfair Labor Practices (ULP). ${ }^{59}$

Union activists organized Portland's first Jobs with Justice action in 1988, but it would it take another three years before CWA organizers successfully chartered a branch. As part of its founding objectives, the organization aimed to establish alliances between communities of color and the city's labor movement. ${ }^{60}$ By September 1991, the coalition under the direction of CWA organizer Margaret Butler began to make an impact on local

\footnotetext{
${ }^{57}$ Eric Larson, Jobs with Justice: 25 Years, 25 Voices (Oakland: PM Press, 2013), 3.

${ }^{58}$ Jeremy Smith, “'Jobs with Justice' Activists Hope for Warming Relationship with AFL-CIO," Labor Notes, August 1996, 5.

59 "NLRB Target of National Protest," Northwest Labor Press, June 4, 1993, 1, 10.

60 "Jobs with Justice Active," Northwest Labor Press, May 3, 1991, 9.
} 
labor fights, winning commendation from union officials. "Jobs with Justice is more than a good idea," wrote Teamsters Local 206 Secretary-Treasurer Tom Leedham in a letter to the editor in the Northwest Labor Press, "it's an idea that works." ${ }^{61}$ Leedham went on to detail how a recent Jobs with Justice action aided his union's contract negotiations with a local hotel and urged other union to support the coalition.

Throughout the 1980s and 1990s, economic justice and workers' rights advocates across the country opened worker centers and advanced living wage ordinances as way to implement the benefits of collective action and collective bargaining for workers often unorganized by mainstream unions. Worker centers, community-based organizations assisting low-wage workers with a wide spectrum of services, first began opening in the 1970s and increasingly filled the organizing void among marginalized and immigrant workers. Labor relations specialist Janice Fine argued in her study of worker centers that their influence and significance grew as the power of unions declined as they increasingly refused to organize employees in small, typically retail or food-service workplaces. The number of centers nationally increased rapidly from ten in 1989 to twenty-nine by 2000 . These facilities were often funded by faith and service organizations and based among the growing number of suburban and urban Latino and Southeast Asian immigrants. ${ }^{62}$

A few unions, particularly HERE, embraced a collaborative relationship with worker centers. During the 1990s, the Portland local union formed the Hotel Workers' Organizing Committee, later restructuring into the Workers' Organizing Committee (WOC). WOC operated out of a storefront on East Burnside Street and SE Eight Avenue,

${ }^{61}$ Tom Leedham, letter to editor, Northwest Labor Press, September 6, 1991, 14.

62 Janice Fine, Worker Centers: Organizing Communities at the Edge of the Dream (Ithaca, N.Y.: Cornell University Press, 2006), 10-11. 
providing services and organizational support to low wage workers. The organization became independent of the union in the late 1990s, and served as the precursor for the Voz Workers' Rights Education Project. Additionally, independent unions such as Oregon's Pineros y Campesinos Unidos del Noroeste, founded in 1985, and Florida's Coalition of Immokalee Workers, founded in 1993, combined the community building, member services, and media tactics often characteristic of worker centers with the direct action and collective bargaining strategies commonly associated with unions.

Economic justice activists in the 1990s circumvented collective bargaining agreements and lagging adjustments to the minimum wage by pressuring local municipalities to pay their employees and subcontracted workers a "living wage" that could support a family of three to four. These campaigns helped popularize the term "living wage" among activists, but the efforts received pushback from local chambers of commerce and nationally from the Employment Policies Institute because the laws targeted private sector employers who used public funds. As organizers showed considerable ambition through these campaigns described "as one of the most significant signs of grassroots awakening around economic justice," their demands reflected a pragmatism based upon local conditions resulting in a variance of demands between $\$ 6.50$ to $\$ 12.00$ per hour, with the typical campaign demanding $\$ 8.75$ per hour. ${ }^{63}$ Activists grounded in faith and community organizations, and aided with national support from Jobs with justice and the Association of Community Organization for Reform Now (ACORN), passed fifty-nine living wage ordinances across the country by

${ }^{63}$ David Reynolds and Jen Kern, "Labor and the Living-Wage Movement," WorkingUSA 5, no. 3 (20012002): 17; Leah Samuel, "Living Wage Campaigns Become a Movement," Labor Notes, July 1999, 1. 
2000 with dozens more in the process of organizing. ${ }^{64}$ While these campaigns generally began outside the institutional labor movement or as a fringe efforts of locals, such as the 1994 Baltimore, Maryland campaign, the AFL-CIO's new national leadership and its local Central Labor Councils increased their involvement in living wage projects. The labor federation voted to nationally endorse the living wage initiative in 1997 and collaborated in the 1998 Los Angeles airport campaign. Ultimately, however, enforcement of living wage ordinances without community or union oversight proved a barrier to effective implementation, as occurred in Portland where the city passed an ordinance in 1996 only for the city to ignore the law for two years before activists organized for a revised measure ${ }^{65}$ At that point, a coalition of thirty-five labor, religious, and community groups (including the AFL-CIO's Northwest Oregon Labor Council) successfully pressured the City Council to expand its living wage ordinance and give Portland's Jobs with Justice chapter a role in monitoring its enforcement. ${ }^{66}$

The changing nature of the workforce meant that if organized labor hoped to continue its revitalization on past the 1990s, unions needed to shift attention away from the familiar manufacturing workforce that built the $\mathrm{CIO}$, but had been on decline since the 1970s, to the increasing numbers of retail and service employees at big box retailers, such as Walmart. Unions that tried to organize isolated Walmart stores or distributions centers in the 1970s and 1980s proved terribly outmatched by pioneer union avoidance consultant John E. Tate, who coached Walton and store management on strategies and

\footnotetext{
${ }^{64}$ Stephanie Luce, Fighting for a Living Wage (Ithaca, N.Y.: Cornell University Press, 2004), 219-222. ${ }^{65}$ David Reynolds, "The Living Wage Movement Sweeps the Nation," WorkingUSA, September/October (1999): 62, 76.

66 "Living Wage Initiative Moves Towards Passage," Northwest Labor Press, February 20, 1998; "Portland City Council OK’s New Living Wage," Northwest Labor Press, May 1, 1998.
} 
tactics to defeat union drives, including captive-audience speeches meant to dissuade employees from supporting a union through a "mix of bluster and contrition," as one activist described it. ${ }^{67}$ In 1989, the United Food and Commercial Workers (UFCW) inaugurated an external public campaign against Walmart that has unofficially never ended, which has proved more of a defensive effort to try to limit the expansion of its superstores than a committed effort to organize the workforce. Tate's success inspired other employers to hire him or replicate his practices, which emphasized employee loyalty to management and a philosophical realignment of unions as unnecessary third party agents characterized as "nothing but blood sucking parasites living off the productive labor of people who work for a living." 68 Ultimately, Nelson Lichtenstein attributed the success of Walmart and similar big box retailers in the 1990s and after to their ability to outsource risk and instability upon employees and suppliers. ${ }^{69}$

\section{A Survey of Portland's Labor History: 1900-2000}

An understanding of the city's labor history must begin with the state's formation as a white homeland within the United States intentionally constructed through institutional racism. The state's 1859 constitution aligned itself with other free states of the Union, but distinguished itself as the only state to constitutionally exclude African Americans from working, buying property, or living within its borders. Such discrimination, which passed by popular vote, compelled historian Egbert S. Oliver to conclude in his study of the debate surrounding exclusion that African Americans who

\footnotetext{
${ }^{67}$ Bob Ortega, “Organizing Wal-Mart: An Anti-Union Company Bests Labor,” WorkingUSA, (January/February 1999): 43.

${ }^{68}$ Nelson Lichtenstein, The Retail Revolution: How Wal-Mart Created a Brave New World of Business (New York: Metropolitan Books, 2009), 196.

${ }^{69}$ Lichtenstein, The Retail Revolution, 346.
} 
resided or made homes in Oregon, "were essentially illegal aliens," in the state. ${ }^{70}$ Chinese and Japanese immigrants, as well as Native Americans, faced similar exclusions and discriminations throughout the late nineteenth century. Simultaneously, as these communities confronted institutional racism, they became the target of white workingclass resentment and hatred that intensified during periods of economic crisis. These social conditions, coupled with the trends of capitalist economic development, resulted in Portland historically having the most diverse population within one of the least racially diverse states in the Union. As a result, many Portland labor unions did not confront the issue of integration or internal racism until the dramatic demographic changes the city experienced during World War II.

Generally, Portland's twentieth-century labor history is segmented into three sequential, chronological, and developmental stages: labor's rise prior to 1935, its peak of influence on through the 1960s, and its slow decline in the years that followed before its revitalization in the 1990s. While the proportion of unionized workers in Portland measured 21.7 percent in 1986, its share for the combined Portland-Vancouver region in 1999 measured only 15.1 percent. ${ }^{71}$ Historically, organized labor's power has rested primarily on its ability to organize workers into unions and to leverage its collective economic power to win concessions and control production, most commonly through the use of the strike. Community support, defined broadly in this thesis as the solidarity of both the labor community and those of the "middling class," proved a critical component

\footnotetext{
${ }^{70}$ Egbert S. Oliver, “Obden Dickinson and the 'Negro Question' in Salem,” Oregon Historical Quarterly Vol 92. No. 1 (Spring 1991), 8.

${ }^{71}$ Metropolitan Area: Union Membership, Coverage, Density, and Employment by Metropolitan Area and Sector, 1986-2014, accessed May 27, 2016, http://unionstats.com/.
} 
to organized labor's ability to form unions, take economic action, and acquire political influence in the twentieth century. ${ }^{72}$ Reciprocally, the Portland business community's capacity to resist unionization and maintain its unilateral control of the labor process depended upon employers' ability to identify a community of interest, act together, and compel city officials to dispatch the police on its side during labor conflicts.

One of Portland's first recorded union organizing campaigns to bring the community into the street to support a labor cause was the contentious 1906 trolley car strike. In December of that year, the Amalgamated Association of Street and Electric Railway Employes of America launched a strike against the Portland Railway, Light \& Power Co. seeking union recognition for six hundred employees as well as economic gains. The workers demanded a ten-hour day with a raise in wages, plus the reinstatement of a terminated union member, and an end to the employer's practice of photographing employees for identification purposes. "The company," the Vice-President of the streetcar operator defiantly proclaimed, "will not recognize any union among our men," and thwarted a threatened strike in July by dissuading workers from participating when the union provided forty-eight hours' notice of its intended action. ${ }^{73}$ In response, the union sprung a secretly planned work stoppage against the company on the afternoon of December 15, shutting down the streetcar service in less than three hours. "Such

\footnotetext{
${ }^{72}$ Robert D. Johnston, The Radical Middle Class: Populist Democracy and the Questions of Capitalism in Progressive Era Portland, Oregon (Princeton, New Jersey: Princeton University Press, 2003); The city's Central Labor Council established the Portland Labor Press in 1900 to inform the growing number of unionized craft workers among the city's 90,0000 residents of events, meetings, and large selection of advertisements for businesses carrying the union label.

73 "Street Car Strike Seems Inevitable," Morning Oregonian, July 18, 1906, 1.
} 
demonstrations as those that attended the strike had never been on the streets of Portland," reported the Oregonian the next day. ${ }^{74}$

The general sentiment of Portlanders witnessing the beginning of this unexpected strike and disruption to their transit was of overwhelming support. "SUCCESS OF TIEUP IS DUE TO CROWD," announced the Oregonian, "People on the streets take sides with strikers at outset of trouble." 75 As the night progressed, the crowd on the street grew into the thousands, aiding union leaders with the task of compelling workers to leave their street cars and join the walkout. The police, also caught by surprise by the strike and the public's enthusiasm, proved incapable of dispersing the crowd. When it became clear the union had prevailed on the first night of its strike, supporters proudly announced "We'll walk!", referring to the extra effort needed to complete their commute home after helping shut down street car service for the night. Despite expressions of continued community support over the next several days, however, the police and streetcar management collaborated in the restoration and protection of service, effectively defeating the strike within a week.

In 1907 the Industrial Workers of the World (IWW) launched its first industrial action along the West Coast in Portland, leading over two thousand sawmill workers in an impromptu strike that lasted forty days. The action began in March when several sawmill workers walked off the job demanding a nine-hour day and $\$ 2.50$ minimum daily wage. IWW organizers stepped in to assist the workers and spread the work stoppage across town, shutting down nearly every mill in Portland for ten days. While the local

\footnotetext{
74 “Strikers Tie Up All Carlines," Sunday Oregonian, December 16, 1906, 1.

75 "Strikers Tie Up All Carlines," Sunday Oregonian, 1-2.
} 
press and the public responded positively to the IWW's non-violent strike, lumber mill owners and the AFL craft unions discovered a mutual interest in defeating the burgeoning industrial union's first big push on the West Coast. In retrospect, IWW historians Fred Thompson and Melvyn Dubofsky both agreed that this strike sent "shock waves" through Washington and California and laid the foundation for radical organization among Western loggers in the years to come. ${ }^{76}$

In the summer of 1913, forty women at the Oregon Packing Co. struck for higher wages, shorter hours, and safety improvements at the Southeast Portland fruit cannery located on SE Belmont Street. ${ }^{77}$ As was also the case with the sawmill workers in 1907 and typical of that era, the workers made demands and walked-out without previous recognition of a union. The Portland women's cannery strike occurred on the heels of similar, but larger, IWW led strikes among working-class women on the East Coast in Lawrence, Massachusetts in 1912 and Paterson, New Jersey in 1913. In Portland, IWW organizers Tom Burns, Rudulph Schwab, and Dr. Marie Equi joined Mary Schwab of the Socialist Labor Party in aiding the workers' organizing efforts. Equi arose as the spokesperson for the striking women, many of whom she knew from her medical practice. The police violence against Equi and the women picketers, plus restraints placed upon public speeches, spurred the AFL to petition for the mayor's recall. Ultimately, the strike ended in a modest wage increase for the workers and an organizational failure for

\footnotetext{
${ }^{76}$ Melvyn Dubofsky, We Shall be All: A History of the IWW (New York: New York Time Books, Co. 1969), 129-131; Fred W. Thompson and Jon Bekken, The Industrial Workers of the World: Its First 100 Years (Cincinnati, Ohio: Industrial Workers of the World, 2006), 26.

${ }^{77}$ Caroline Gleason, "For Working Women in Oregon Revised Code of Ruling on Wage, Hour and Sanitary Conditions Issued by the Industrial Welfare Commission," The Survey Vol. XXXVI, September 9, 1916, p 585-586. The Oregon Packing Co. moved to Vancouver, Washington in 1916.
} 
the IWW. Disagreements over tactics and negotiations during the strike among outsider supporters also drove a wedge between the IWW and many of the city's Progressives, who had rallied to the cause of the women laborers. ${ }^{78}$

Comparatively, women working within the waitressing occupation and the garment industry found greater success with AFL unionization efforts during the early and midcentury. While Portland's Waiters and Waitress Union Local 189 first organized in 1901, unionization among women increased following World War I in cities such as Portland, where waitresses fought to create locals exclusively for women. Led by Agnes Quinn and Gertrude Sweet for multiple decades, Waitress' Local 305 in Portland operated from 1921 to 1976, reaching a peak membership of two thousand members in $1948 .^{79}$ In another instance, women in the garment industry acquired a $\$ 1$ increase in weekly wages and a reduction of hours from sixty to forty-eight between 1903 and 1915 through the efforts of the United Garment Workers of America Local 228. ${ }^{80}$ Furthermore, women, including Elizabeth Gee, found leadership positions within the union in the 1910s and 1920s, while the predominantly women workforce maintained a reputation of aiding striking workers, including refraining from riding streetcars during the 1906 strike. This commitment to cross-union solidarity continued through the Great Depression through various textile and garment unions, including participating in picket duty for striking longshoremen in $1934 .{ }^{81}$

\footnotetext{
${ }^{78}$ Michael Helquist, Marie Equi: Radical Politics and Outlaw Passions (Corvallis, Oregon: Oregon State University Press, 2015), 119-122.

${ }^{79}$ Dorothy Sue Cobble, Dishing It Out: Waitresses and Their Unions in the Twentieth Century (Chicago: University of Illinois Press, 1991), 215.

${ }^{80}$ O.P. Hoff, Sixth Annual Report of the Bureau of Labor Statistics and Inspector of Factories and Workshops of the State of Oregon (Salem, Oregon: State Printing Department, 1914), 38.

${ }^{81}$ Gleason, "For Working Women," 585-586.
} 
Organized in 1868, the Longshoremen's Protective Union stood as Portland's first waterfront labor organization. In June 1916, five waterfront union locals totaling a thousand workers struck for nearly two months alongside dockworkers in other port cities on the West Coast. In response, Portland's business community rallied for an open shop ballot initiative amendment to the state's constitution. The Waterfront Employers' Association defeated the strike by dividing the longshore union from the maritime and the ground transport unions, as well as effectively bringing in replacement workers under armed guard. In 1919 and again in 1922, dockworkers with the International Longshoremen's Association (ILA) Local 6 lost strikes for higher wages, safety improvements, and control over hiring, leading to the ILA ceding all its bargaining power on Portland's waterfront until a resurgence in 1934. Disputes between ILA and IWW longshoremen over access to work in the preceding years to the 1922 strike had compromised unity on the picket line, aiding to the ILA's devastating defeat. ${ }^{82}$

The ILA's 1934 strike was part and parcel of a working-class social movement occurring around the country that emerged from rank-and-file protest over corporate capitalism and accompanied the rapid growth of industrial unions in the 1930s and 1940s. Historian Carl Abbott asserted that in this era Portland "was two cities side by side," one that consisted of "militant union members, skid-road workers and the periodically unemployed" alongside a middle class that saw the city as "solid, sober, politically and socially conventional. ${ }^{" 83}$ The ILA, joined by other maritime unions including the

\footnotetext{
${ }^{82}$ Roger Buchanan, Dock Strike: History of the 1934 Waterfront Strike in Portland, Oregon (Everett, Washington: The Working Press, 1975), 15-30; William W. Pilcher, The Portland Longshoremen: A Dispersed Urban Community (New York: Holt, Rinehart, and Winston, Inc, 1972), 31-32.

${ }^{83}$ Carl Abbott, Portland in Three Centuries (Corvallis, Oregon: Oregon State University Press, 2011), 116.
} 
Communist Party's Marine Workers Industrial Union, commenced a strike in May at every port city on the West Coast, which at its peak involved 35,000 maritime workers. ${ }^{84}$ The ILA longshoremen sought the recognition of their union, as well as control over hiring, wage increases, and safety improvement.

Wobblies, IWW members or adherents to the syndicalist union's mission of industrial unionism, led the strike in Portland from within the ranks of the ILA ${ }^{85}$ These militant longshoremen helped win the strike by organizing both deep within the ranks of maritime workers and wide within the community. Portland's unemployed, labor unions, farmers, small business communities, students, sex workers, and cab drivers provided sustaining morale and material support to the longshoremen throughout the strike, while the business elite organized into the Citizens Emergency League to assist in financing and coordinating strikebreaking. ${ }^{86}$ Over the course of the eighty-three-day walkout, the clash between the longshoremen and employers evolved into a larger conflict between opposing social classes. The tension erupted on the morning of July 11, when one hundred policemen opened fire using shotguns and pistols upon unarmed picketers in Portland's Pier Park. The strike ended soon after on July 31 when the employers conceded to the union's demands, averting both the possible deployment of the National Guard and a general strike. ${ }^{87}$

\footnotetext{
${ }^{84}$ Buchanan, Dock Strike.

${ }^{85}$ Pilcher, The Portland Longshoremen, 42-43.

${ }^{86}$ William Bigelow and Norman Diamond, "Agitate, Educate, Organize: Portland, 1934," Oregon Historical Quarterly 89, no. 1 (1988): 16-27; Michael Munk, "Portland's 'Silk Stocking Mob': The Citizens Emergency League in the 1934 Maritime Strike," Pacific Northwest Quarterly 91, no. 3 (2000) 152-160.

${ }^{87}$ Buchanan, Dock Strike, 95-96.
} 
Successes such as the ILA's 1934 strike and the passage of the National Labor Relations Act of 1935 spurred industrial union organizing campaigns by both the CIO and its main rival, the AFL, throughout the remainder of the decade. The 1935 AFL timber workers' strike involved tens of thousands of workers across several western states lasting three months. In the years that followed, the high demand for labor and uninterrupted production brought on by World War II generally benefitted unions by providing steady work, supportive labor laws, and a position of influence within the government. The demand for labor by Portland's wartime manufacturing operations, particularly the Kaiser shipyards, exceeded the city's pre-war supply. Out of state workers, including thousands of African Americans, migrated to Portland for these wartime production jobs, resulting in a 32 percent population increase between 1940 and 1944. ${ }^{88}$ Portlanders welcomed the new arrivals for their contributions to the war effort, but saw them as temporary residents who would leave town once the war boom was over. Whereas the federal government constructed temporary war time housing regardless of race and banned discrimination in wartime employment in 1941, employers instead relegated African American workers to unskilled laborer jobs. At the same time, labor organizations, including the Boilermakers Union, collaborated in such discrimination by relegating black workers to second class status within the union or forming segregated unions. In response to such treatment, skilled African American workers formed the Shipyard Negro Organization for Victory and threatened to strike for the right "to work our trades on equal status with whites." 89 The fight to integrate the city's unions

\footnotetext{
${ }^{88}$ Abbott, Portland in Three Centuries, 119.

${ }^{89}$ Lucas N.N. Burke and Judson L. Jeffries, The Portland Black Panthers: Empowering Albina and Remaking a City (Seattle: University of Washington Press, 2016), 33.
} 
(including the ILWU), challenging exclusions based on race and gender, became a prominent issue throughout the next several decades and intersected with the broader civil rights and women's movements.

Portland's political and public support for organized labor began to turn in the 1950s as evidence of corruption and violence within the Teamsters' union threatened to tarnish the reputation of the broader labor movement. From 1956 to 1960, Teamsters' officers in Seattle and Portland came under scrutiny for corruption by the Oregonian and a congressional investigation. Journalists Wallace Turner and William Lambert reported that union officers, including President Dave Beck and Vice President Frank Brewster, directed organizers to leverage the union's power in the distribution sector of the formal economy to control and profit from Portland's vice sector. Turner and Lambert's prizewinning report precipitated a 1956 Oregon grand jury indictment of the county's district attorney, the city's chief of police, and local organized crime figures. A year later, the U.S. Senate initiated the McClellan Committee to investigate union racketeering, attracting coverage by the national television networks. The news depicted Portland's corrupt union officials, gangsters, and politicians associated together on a national stage. Simultaneously, a selection of Hollywood films, including On the Waterfront (1954) and Slaughter on Tenth Avenue (1957), featured union members and officers confronting violent corruption from the mob. In a study of how movies have historically depicted organized labor, media critic William J. Puette concluded that Hollywood in the 1950s equated unions and organized crime as one and the same, a stereotype perpetuated on 
through the 1980s. ${ }^{90}$ Ultimately, the corruption of Portland's Teamsters and the ensuing public investigations damaged the labor movement's public reputation locally and facilitated a negative turn in the public opinion of unions nationally.

Despite significant community support for unions during Portland's 1959-1965 newspaper strike, the cause ended as a major defeat for the local labor movement and set a corporate precedent for instituting mechanization over union protest within the newspaper business. ${ }^{91}$ Printers had organized early on in Portland's history, establishing unions in the 1850 s and 1860 s as some of the first organized labor associations in the city and maintained decent relationships with the newspaper families. In 1950, however, Sam Newhouse's newspaper conglomerate, Advance Publications, purchased the morning Oregonian and sought to acquire the afternoon Oregon Journal, which lingered in probate following the death of the last family heir. The newspapers bargained with their unions jointly, with the Oregonian management now taking charge. As the Newhouse executives, who sought to automate printing and reduce labor costs, remained steadfast, Stereotypers Local 49 gained no ground in attempting to negotiate over the implementation of new labor-saving technology.

In November 1959, the Stereotypers directed a strike of a dozen unions comprising 850 members against Oregon's two most prominent daily newspapers. Workers picketed outside both the Journal's headquarters on SW Front Avenue and the

\footnotetext{
${ }^{90}$ William J. Pruette, Through Jaundiced Eyes: How the Media View Organized Labor (Ithaca, New York: ILR Press, 1992), 22-25.

${ }^{91}$ Gene Klare "Let me say this about that," Northwest Labor Press, January, 19 2001, accessed May 13, 2016, https://nwlaborpress.org/klare/011901.html; Gene Klare "Let me say this about that," Northwest Labor Press, June 6, 2003, accessed May 13, 2016, http://archive.is/i49Vm; Caled Diehl, "The Portland Newspaper Wars of the 1960s," Portland Monthly, November 23, 2015, accessed May 13, 2016, http://www.pdxmonthly.com/articles/2015/11/23/the-portland-newspaper-wars-of-the-1960s.
} 
Oregonian's offices, surrounding the building that covered an entire block on SW Broadway. As Republican governor Mark Hatfield and future governor and television news commentator Tom McCall encouraged the Newhouse corporation to bargain with its employees, tens of thousands of Portlanders canceled their subscriptions to show support for the unions. Journalists from the Newspapers Guild, including Wallace Turner, refused to cross the picket lines. Turner and dozens of other strikers choose to assist the formation of the Portland Reporter, a daily newspaper published between 1960 and 1964 by the striking union workers with a peak circulation of $78,000 .{ }^{92}$ In anticipation of a strike, which the unions conjectured was intentionally provoked, the Newhouse corporation invested in strike insurance and hired replacement workers from out of town. Management housed the strikebreakers at the Hungerford Hotel across from the Oregonian building on SW Columbia Street. When Mayor Terry Schrunk banned the use of mass picketing, the unions lost their most effective tactic to halting production. ${ }^{93}$ The January 1960 bombing of ten newspaper delivery trucks by men hired by Levi McDonald, an Oregonian employee and part of the negotiating team for the Stereotypers local, raised public concerns over the direction of the strike. The court indicted McDonald and the bombers, but found no evidence of union direction. On the contrary, journalist Gene Klare, a striking journalist from the Portland Reporter and later editor of the Northwest Labor Press, would argue that Newhouse management conspired with McDonald to bomb the trucks in order to sway public opinion, city officials, and the

\footnotetext{
${ }^{92}$ Richard Heinzkill, "A Brief History of Newspaper Publishing in Oregon" University of Oregon, August 1993, accessed May 13, 2016, https://library.uoregon.edu/govdocs/indexing/newspaperhistory.html. ${ }^{93}$ Norm Diamond, "Portland Labor History Tour," Lewis \& Clark College, May 2001, accessed May 13, 2015, http://college.lclark.edu/programs/political_economy/student_resources/labor_tour/; Bill Nygren, Radicals in the Rose City (Portland, Oregon: Northwest History Press, 2013), 1-7.
} 
police against the unions. ${ }^{94}$ Whatever the case, both the strike and the Portland Reporter had collapsed by 1965 , and Newhouse consolidated control of both major daily papers. The defeat meant permanent replacement for many of the workers who walked off the job because the NLRB had ruled the strike illegal in 1963, releasing the Oregonian from any obligation to rehire the production workers.

Portland's labor movement experienced the same general decline of political influence, as well as decreasing private sector membership and bargaining strength, that affected the labor movement nationally in the 1970s and 1980s. During the preceding decade, the New Left and student movement, which formed around Portland State University and Reed College, provided a jolt of radical rank-and-file organizing within the local labor movement as radical organizers took jobs in factories seeking to organize the classic segments of the working class. Through established unions or new organizations, including the Workers Revolutionary Movement (WoRM) and Revolutionary Union (RU), radicals participated in strikes at ESCO Steel, Fry Roofing, Precision Castparts, and elsewhere. ${ }^{95}$

The membership gains made by Oregon's unions in the 1970s and across the country came in the organization of public sector workers, including teachers, social service workers, office workers, and even police officers. The AFL ended its unionization efforts among police officers following the 1919 Boston police strike. Nevertheless, the Portland Police Association (PPA) formed in 1942 with a charter from American

\footnotetext{
${ }^{94}$ Gene Klare "Let me say this about that," Northwest Labor Press, June 30, 2003, http://www.nwlaborpress.org/opinion/062003.html, Internet Archive, accessed May 13, 2016, http://web.archive.org/web/20030906090906/http://www.nwlaborpress.org/opinion/062003.html. ${ }^{95}$ Nygren, Radicals in the Rose City, 253-279.
} 
Federation of State, County, and Municipal Employees (AFSCME) and became an affiliate of the AFL's Central Labor Council. Since the city refused to recognize the PPA as the exclusive bargaining agent and AFSCME required the officers to adopt a no strike pledge to their constitution, the PPA, like most other city employees, could not acquire a collective bargaining agreement and could only petition city council for improved wages, hours, and benefits.

The conditions for unionization changed dramatically in 1968 when Portland's city council opened the door to collective bargaining with its employees. That same year, the PPA members elected David Callison, the son of a union sawmill worker, as its president and he quickly began to mobilize his fellow officers. Callison successfully leveraged the power of Portland's labor community against the city to acquire the nation's first collective bargaining agreement for police officers. Organized labor's support, including the Central Labor Council endorsement of the PPA's demands, proved crucial to the officers' cause. Both the Teamsters and the ILWU respected the picket lines set up by the police at the city's docks, shutting down port traffic for three days and compelling the city council to sign a contract with the PPA. Nevertheless, the PPA's participation alongside organized labor proved short lived once it guaranteed a contract, as both AFSCME and the PPA split bitterly in $1970 .{ }^{96}$

${ }^{96}$ Susan G. Hauser, Pickets, Pistols and Politics (Portland, Oregon: Portland Police Association, 1996), 2$4,18-26,41-72$. 


\section{Chapter 2}

\section{Historical Developments in the Retail Book Sector}

By the end of the twentieth century, booksellers had become a major component of the retail sector. In the years after World War II, consumer habits involving books changed dramatically, altering the triangular retail relationship between bookstore employers, customers, and employees. Journalism scholar, Jon Bekken, has asserted that these changes mattered because bookselling represented a "vital cultural sector," distinguishably different from other retail business who used similar strategies to increase their profitability. Bookstores, suggested Bekken, possessed "a central role in the dissemination of ideas." ${ }^{.97}$ The authors of Books: The Culture and Commerce of Publishing (1982) concurred, and further recognized that this tension between commerce and culture, as well as criticism of over-commercialization, has existed within bookselling since the emergence of capitalism. ${ }^{98}$ Nonetheless, "While publishers may believe their problems are unique," stated the authors of Books, "they are in fact endemic in modern industrial societies, which are plagued with a basic contradiction: while the logic of mass production homogenizes tastes, the relative affluence of the society and the complex division of labor gives rise to specialization and differentiated tastes." 99

\section{The Retail Triangle: Employers, Customers, and Bookstore Clerks}

Department stores and independent bookstores, both often located in urban centers, controlled bookselling in the United States prior to the 1960s. Department stores,

\footnotetext{
${ }^{97}$ Jon Bekken, "Feeding the Dinosaurs: Economic Concentration in the Retail Book Industry," Publishing Research Quarterly (Winter 1997-1998): 5, 21.

${ }^{98}$ Lewis A. Coser, Charles Kadushin, Walter W. Powell, Books: The Culture and Commerce of Publishing (New York: Basic Books, Inc., 1982), 363.

${ }^{99}$ Coser et al., Books, 373.
} 
which grew to retail prominence during the intense urbanization occurring during the first half of the twentieth century, accounted for an estimated 40 to 60 percent of all book sales in $1951 .{ }^{100}$ However, this dominance faded rapidly in the decade as overall declining sales, brought on by the population's residential and consumer movement out of the urban core and into suburban neighborhoods, led to the elimination or downsizing of these stores' book departments. In their place, independent, non-chain bookstore acquired the dominant share of market, amounting to 72 percent of all bookstore sales in 1958. ${ }^{101}$ Modest sized national or regional chains, most notably Doubleday and Brentano's, coexisted unobtrusively with local independents throughout the 1960s.

During the 1970s, the subsequent generation of chain stores, most notably Waldenbooks and B. Dalton's, represented what Laura Miller described as "new chains," characterized by aggressive expansion and a rationalization of the distribution process through the aid of new technology and supermarket inspired merchandising strategies. Between 1972 and 1977, book chains expanded at a rate of 101 percent. These corporations often focused on new, enclosed malls featuring ample parking as well as weekend and evening hours to serve a newly affluent and increasingly educated suburban population. ${ }^{102}$ By 1980 , Waldenbooks operated 704 locations in all fifty states while B. Dalton's maintained 526 outlets. ${ }^{103}$ Furthermore, book sales by chains with twenty-five or more outlets rose by 194 percent between 1972 and $1977 .{ }^{104}$ In the 1980s, the success

\footnotetext{
${ }^{100}$ Laura J. Miller, "Selling the Product," In A History of the Book in America. Vol. 5, The Enduring Book: Print Culture in Postwar America, edited by David Paul Nord, Joan Shelley Rubin, and Michael Schudson (Chapel Hill, N.C., University of North Carolina Press, 2009), 92.

${ }^{101}$ Coser et al., Books, 336.

102 Coser et al., Books, 350.

${ }^{103}$ Coser et al., Books, 349.

${ }^{104}$ Coser et al., Books, 350.
} 
of the new chains either drove independent stores out of business, or compelled them to differentiate themselves from the chains by offering knowledgeable and specialized services, cafes, and space for community events and book groups.

The arrival of the superstore bookstore chains Borders and Barnes \& Noble in the 1990s both followed and precipitated the big-box store trend in the broader retail sector, as well as disrupted the stasis created in the previous decade between independents and chain bookstores. With new infusions of investment capital, superstores rapidly created a near monopoly on bookselling in the 1990s by acquiring small chain competitors, sharply discounting prices, and offering specialty services. Borders and Barnes \& Noble combined the best services and ambiances found in independent bookstores with the discount pricing and merchandising strategies of the chain stores in a single, warehouse sized superstore. As these superstores borrowed strategies from the independents, so did the independents begin to look more like chain stores by the late 1990s. "With independents' heightened emphasis on expansion, marketing, and technology," wrote Publishers Weekly in 1998 about a trend among stores including Powell's Books, "they are, ironically, starting to resemble the chains they revile." ${ }^{\prime 05}$ As regionally notable independents including Books \& Co., Oxford Books, and Taylors Bookstores all closed in the late 1990s after over twenty years of business, the American Booksellers Association (ABA) responded that the independents that survived this period of "market absorption" proved "stronger" and more "innovative."106

\footnotetext{
${ }^{105}$ Karen Angel, “Are Independents Making a Comeback?” Publisher's Weekly, June 8, 1998, 21-22.

${ }^{106}$ Angel, “Are Independents Making a Comeback?” 21.
} 
Borders, first opened in Ann Arbor, Michigan by brothers Thomas and Louis Borders in 1973, capitalized early on UPC bar-coding and created the pioneering Book Inventory System to centralize and expedite ordering. ${ }^{107}$ Kmart, which already purchased Waldenbooks, acquired Borders in 1992 and aggressively expanded the brand from nineteen to seventy-five stores in three years. Leonard Riggio acquired Barnes \& Noble in 1971, expanded the brand, and fifteen years later acquired B. Dalton's 798 stores. While Borders rose to prominence primarily through the competitive advantages its inventory system provided, a significant factor in Barnes \& Noble's success proved to be its merchandising strategy. Riggio boldly introduced shopping carts in his stores. While simultaneously taking the "stuffiness out of a bookstore" to accommodate customers, not scholars, Riggio tapped the consumer's vain desire to take on scholarly appearances, noting that customers buy volumes of books as "shelf fillers, in order to project images of themselves through their collections." 108 Riggio's quest for a greater share of the national market led him to challenge and overtake the Borders Group in the superstore sector, with Barnes \& Noble operating 431 units compared to Borders' 157 by $1996 .{ }^{109}$ By the end of the decade, however, financial and publishing experts criticized the book market for its saturation. Although, Borders Group and Barnes \& Noble tallied almost $\$ 4.5$ billion in sales in 1996 and accounted for 43.3 percent of bookstore sales a year later, the arrival of internet bookselling and Amazon.com in 1995 would soon make the superstore

\footnotetext{
${ }^{107}$ Daniel M.G. Raff, "Superstores and the Evolution of Firm Capabilities in American Bookselling," Strategic Management Journal 21 (2000): 1046-1047.

${ }^{108}$ Raff, "Superstores," 1050.

${ }^{109}$ Raff, "Superstores," 1053; Bekken, "Feeding the Dinosaurs," 8.
} 
chains appear more like "lumbering dinosaurs" than the industry titans they seemed only a few years earlier. ${ }^{110}$

The power relationship between publishers and booksellers has for most of history been tilted in favor of the publisher; however, chain stores began to alter this balance of power. Similarly, while the authors of Books observed in the 1980s that chain stores and publishers experienced a "reciprocal dependency," nearly thirty years later Laura J. Miller argued that the chain stores altered the balance of power in the industry to the point that publishers became dependent upon them. ${ }^{111}$ The ABA's record of civil lawsuits against the chains, the superstores, and Amazon.com in the interest of independent bookstores, who often survived on the margins of the industry, illustrated the shifting power between publishers and retailers. First, in the 1980s the ABA filed suits against several major publishers, who at the time were also under investigation by the Federal Trade Commission, arguing that publishers gave chains special accommodations not received by ABA members. Following this, the ABA shifted much of its criticism from the publishers to the chains, announcing in 1998 that they have "now decided to strike at what we think is the heart of the problem, the power of the chains." ${ }^{112}$ The independent bookstores claimed that the superstore chains and their subsidiaries pressured the publishers into giving them significant discounts unavailable to independents, creating an unfair competitive advantage. The 2015 ABA request for a Department of Justice investigation into Amazon for anti-trust violations has revealed

\footnotetext{
${ }^{110}$ Miller, "Selling the Product," 102; Bekken, "Feeding the Dinosaurs," 9, 21.

${ }^{111}$ Coser et al., Books, 351; Miller, "Selling the Product," 92.

112 G. Bruce Knecht, "Independent Bookstores Are Suing Borders Group and Barnes \& Noble," Wall Street Journal, March 19, 1998, accessed April 19, 2016, http://www.wsj.com/articles/SB89026929780840000.
} 
how independent booksellers' fear of the publishers in the 1980s and retailers in the 1990s have combined as Amazon has become the world's largest publisher and retailer of new books. ${ }^{113}$ It can be argued that these business trends democratized bookselling in the United States since it was no longer a geniocracy limited to urban West Coast and Northeast metropolitan areas, but increasingly occurred in the suburban environment and spread to rural and southern areas of the country where bookstores were historically sparse.

Consumer habits accompanied structural shifts in bookselling. Book shopping increasingly evolved from an act of indulgence or intellectual curiosity to a common leisure activity in the late twentieth century. During the era of bookselling before the new chains, booksellers organized their display by publisher to expedite inventory management. Thus, the consumer relied as heavily on the clerk's expert knowledge of authors and book titles as they did on shelving organization. When in the 1970s new chains broke free from this antiquated business model by utilizing new technology and merchandising strategies, they did so to attract a modern consumer, desiring of unpretentious self-service when shopping. In her observations of how the new chain stores changed bookselling in the 1970s, Laura Miller noted that by moving to the suburbs "it lessened the elite aura" of shopping for books and brought the bookstore "down to the level of the supermarket across the parking lot or the teen jeans outlet next door." ${ }^{114}$ As chain stores increasingly absorbed a greater share of the broader market

\footnotetext{
${ }^{113}$ David Grogan, "Authors, ABA to DOJ: Investigate Amazon's Abuse of Its Dominance in the Book Market," Bookselling this Week, American Booksellers Association, July 13, 2015, accessed May 26, 2016, http://www.bookweb.org/news/authors-aba-doj-investigate-amazon\%tE2\%80\%99s-abuse-its-dominancebook-market\#Authors United Letter.

${ }^{114}$ Miller, "Selling the Product," 97.
} 
through a limited popular collection, customers also benefitted from how independents turned to specialized retailing with religious, children, technical, or women's books. The Borders and Barnes \& Noble superstores of the 1990s appealed to the customer base of both the small chains and the independent stores because the superstores combined discount pricing located in suburban centers with specialty services, cafes, and community events. Reflecting on a half century of developments in bookselling, Miller concluded that retailers had established the activity of "shopping for books" as "one of the quintessential expressions of consumption as a leisure activity." 115

The identity and responsibilities of book clerks that existed in the 1950s and the earlier heyday of department store bookselling reverberated throughout the remainder of the twentieth century. The original chains, Doubleday and Brentano's, and the traditional independents continued the legacy of a department store retailing model in which the bookseller's expertise of titles and shelving organizations provided them a tangible skill set. Store owners expected employees to possess an extensive knowledge of books, authors, and subjects. Prior to the 1970s, bookstores shelved their display stock by publisher to ease inventory counting and reordering. As a result, the book clerk also needed to maintain an intricate understanding of publishers and titles in order to locate books for customers. Waldenbooks and B. Dalton's significantly rationalized the work process, effectively altering the responsibilities and expectations that employers had for book clerks as such changes reduced labor hours and the reliance on the employee's experience. Unlike other book chains, Borders formalized its expectations of employees in an applicant screening process to demonstrate they had a sufficient knowledge of

\footnotetext{
${ }^{115}$ Miller, "Selling the Product," 106.
} 
books, authors, and subjects before being hired. Indeed, in the first years of the company, select employees in each section held the title of "buyer" and choose the titles to shelf, a responsibility that derived from job roles in the early era of department stores.

Additionally, buyers also assisted with floor sales and cashier duties. Borders considered them valuable because of their years of experience, product knowledge, and familiarity with what the local consumer wanted. ${ }^{116}$

\section{Bookstore Clerks Join the Union Movement}

The labor movement's groundswell in the 1990s accompanied a period of intense competition and conglomeration within the retail book sector that also paralleled a wave of union campaigns among the nation's largest booksellers. Yet, while unionization for bookstore workers was hardly a new concept, as the United Auto Workers had represented employees at Strand in New York City since 1976 and the ILWU had organized Stacey's Bookstore in San Francisco in the 1950s, these campaigns represented isolated and insular events, as anomalous as the names of the unions suggest. However, seemingly out of nowhere employees at large retail bookstores, including Borders and Barnes \& Noble, initiated over two dozen union drives across the country between 1996 and 2003. These campaigns were predominantly initiated by store workers and not union organizers, and although the campaigns focused narrowly on union recognition and collective bargaining at the individual store level, workers used the newly available internet to share information, coordinate actions, and ultimately create informal national bookstore unions.

${ }^{116}$ Raff, "Superstores," 1046. 
Borders served as the epicenter of book clerk organizing and the primary target for unionization in the mid to late 1990s, and then again in the early 2000s. The Industrial Workers of the World (IWW) and the workers at Borders store \#21 in Philadelphia, Pennsylvania embarked upon the first concerted effort to organize and seek union recognition at one of the national chains in the country. Though the workers lost the election by a 25 to 20 vote in March 1996, the company's subsequent termination of twenty-two-year-old union activist Miriam Fried in June sparked an unexpected international campaign against Borders. Utilizing the internet to share information about Fried's firing, the IWW launched a website to announce the formation of a "cyber picket" of Borders and to coordinate pickets at store locations across the country in eighteen cities, including the company’s downtown Portland store in August $1996 .{ }^{117}$ The boycott campaign garnered national attention after filmmaker Michael Moore refused to cross a picket line at the Philadelphia store in September, and alternatively welcomed Fried and the protest into the store for his book signing event. Borders, once considered a progressive liberal employer by the public, suddenly began receiving demands from progressive cultural figures and organizations, such as Noam Chomsky, Billy Bragg, the National Writers Union, and the Women's International League of Peace and Justice. "Borders manipulates its hippie image," wrote the stalwart progressive magazine The Nation, adding it "uses new-age obfuscations to derail union efforts.",118

\footnotetext{
117 “Borders Cyber Picket,” Why Barnes \& Noble Employees Need A Union! http://booksellersunion.org:80/cgi-bin/BN.cgi, Internet Archive, accessed October 1, 2017, https://web.archive.org/web/20000304180758/http://booksellersunion.org:80/cgi-bin/BN.cgi.

${ }^{118}$ Lisa Featherstone and Emily Gordon, "Borders Belabored," The Nation, February 3, 1997; Bridget Kinsella, "Borders Faces Union Protest, National Boycott Over Firing," Publishers Weekly, December 9, 1996, 14.
} 
Although the IWW continued its relevance for several more years in the struggle to unionize Borders through periodic organizing drives, pickets, and the boycott website, the United Food and Commercial Workers' (UFCW) wider national presence and greater resources propelled the union to the forefront of the Border's campaign. While the UFCW received charges from the IWW of raiding their union drive at the Chicago location, Borders' tested the union's commitment and ability to organize employees in the retail superstore sector. ${ }^{119}$ In the summer of 1996, Borders employees in Chicago and at the company's flagship store in Ann Arbor began organizing with the UFCW, with the Chicago store becoming the first recognized union at any of Borders 157 locations in the country. In the immediate years that followed, the unionized Chicago workers were joined by Borders employees in Des Moines, Iowa (1996); Bryn Mawr, Pennsylvania (1997); and New York City's World Trade Center (1997) who voted for the union. Yet, the UFCW would win as many times as it had lost or withdrew petitions for elections, including at Ann Arbor, Michigan (1996); Stamford, Connecticut (1997); Seattle, Washington (1997); Evanston, Illinois (1997); and twice at a warehouse facility in Harrisburg, Pennsylvania (1996 and 1998). ${ }^{120}$

Believing that there was widespread agitation among employees throughout Borders, the UFCW auspiciously announced a national campaign in October 1997 to

\footnotetext{
${ }^{119}$ Fred W. Thompson and Jon Bekken, The Industrial Workers of the World: Its First 100 Years (Cincinnati, Ohio: Industrial Workers of the World, 2006), 214.

120 "Overview of the Borders Union Drive," Borders Waldenbooks Employee Website, last updated June 8, 1998, http://members.xoom.com/booksort/uframe.htm, Internet Archive, accessed October 1, 2017, https://web.archive.org/web/19990203220545/http://members.xoom.com/booksort/uframe.htm; "Drive Overview," The Borders Books Employee Union Web Site, last updated December 7, 2002, Internet Archive, accessed October 1, 2017, https://web.archive.org/web/20031108153505/http://www.bordersunion.org:80/Content-Navigate-34-14.html; "Why Barnes \& Noble Employees Need A Union!" accessed October 1, 2017, http://booksellersunion.org/.
} 
organize the company's ten thousand employees. Union president Douglas H. Dority pledged the "support, the resources and the unwavering commitment" of the UFCW to the "educated, loyal and committed" Borders employees "seeking a fair reward and opportunity for future growth." ${ }^{\text {"21 }}$ The strategy focused on first acquiring a neutrality pledge from management to not interfere with organizing while simultaneously mobilizing customers to take a visible stance of support for the workers, but this call to action for consumers fell short of joining the boycott called by the IWW. Such optimism and sentiments of "unwavering commitment" proved ephemeral as the UFCW called off the national media campaign targeting the bookstore's liberal reputation in December. "I thought Borders would care more about their publicity," explained UFCW organizer Vanessa Sylvester. Organizer Liza Canada also admitted the union was out of touch with the issues which workers faced in the targeted Michigan stores. ${ }^{122}$

Following this defeat, the UFCW encountered difficulty negotiating contracts for its four union stores or organizing new shops but workers continued to press the company. The union at Bryn Mawr decertified in June 1998 without acquiring a contract, while the agreements for the Chicago, Des Moines, and World Trade Center stores secured only minor economic benefits. Nonetheless, an upsurge in organizing at Borders occurred again in 2002, when employees at the Ann Arbor and Minneapolis stores elected the UFCW. By this time, the UFCW no longer represented the workers at the four previous unionized bookstores. In comparison to the previous efforts, the UFCW acted

\footnotetext{
121 "Statement of Douglas H. Dority International President United Food and Commercial Workers International Union (UFCW) Rally for Borders Employees," Press Release, UFCW, October 1, 1997, http://ufcw.org/100197.html, Internet Archive, accessed May 27, 2016, https://web.archive.org/web/19980213095138/http://ufcw.org/100197.html.

122 Jane Slaughter, "Union Ends Campaign at Borders Books,” Labor Notes, February 1998, 4.
} 
considerably more aggressive in its efforts to secure a contract for the new unionized stores, building strong community coalitions in both cities and engaging in a fifty-fourday strike at the Ann Arbor store that began in November 2003. Workers in Minneapolis received support from the Union of Radical Workers and Writers (URWW), a small "social movement network" organized to "confront, impede, and revise neoliberal policies and practices in the everyday lives of workers of the word." 123 The URWW grew out of the struggle to unionize Borders and went on to host the first conference for activist bookstore workers titled "Resist Retail Nihilism: A Bookstore Workers Organizing Forum" in January 2004.

The Borders Group initially proved slow to respond nationally to the IWW's early union drive, but as union activity became more frequent around the country in the summer of 1996 the company adapted a classic union avoidance strategy to its liberal corporate image. By September 1996 company executives had embarked upon a campaign that included the creation of a "Union Awareness Training for Borders Managers" manual by Vice President of Human Resources Anne Kubeck. In 1998, the manual was leaked to the public and published online by Borders union activists, the IWW, and Mother Jones magazine. Kubeck appeared to have modeled the manual on the works of other union avoidance strategists, such as John Tate and Alfred T. DeMaria, by giving instructions for how management should alert corporate executives about any

\footnotetext{
123 “Mission Statement," Union of Radical Workers and Writers, last updated March 24, 2005, accessed May 27, 2016, http://urww.blogspot.com/2005/03/union-of-radical-workers-and-writers.html; Complete mission statement: "URWW is a social movement network on the front lines of left-labor activism. The URWW network strives to confront, impede, and revise neoliberal policies and practices in the everyday lives of workers of the word. Understanding the larger and ultimate political project of these neoliberal policies and practices to be the abolition of collective action 'for humanity and against neoliberalism,' we seek to establish public platforms and virtual networks for the democratic struggle to work in the first person plural."
} 
suspicious behavior from employees. ${ }^{124}$ Additionally, the guide instructed managers about how "Raising awareness about the specific unions in question can also be enlightening" to employees. "Anytime we are afraid to speak about unions," the manual warns, "we give our employees the impression that there must be something of value to them in a union and therefore encourage their activity to continue." ${ }^{125}$ Management coupled this nuanced strategy by responding to select cases of union activity with a sharp rebuke of the educated workforce it had sought out, while simultaneously attempting to reinforce the futility of challenging retail economics. "We have highly educated employees who consider themselves 'professional,", stated an April 1997 company newsletter, "but who are in reality working at an early level retail job." The newsletter went on to say that, "If you desire an enjoyable job while you figure out what to do with your life, this is a good place to be," but warned employees against trying to make a career from what could "never be a well-paying job." 126

Despite the resistance and the defeats to unionization met by Borders employees, union efforts and messages found resonance with book clerks at Barnes \& Noble, who initiated organizing campaigns in 1997 and 1998 with familiar aspirations, tactics, and principles. Responding to why he contacted the UFCW to help organize a union at the Arlington, Texas Barnes \& Noble, college student James Schram stated that he believed

\footnotetext{
${ }^{124}$ Alfred T. DeMaria authored several books aimed at helping employers defeat union campaigns, including Managing to Stay Non-Union (1979), How Management Wins Union Organizing Campaigns (1980), and Combating the Resurgence of Organized Labor: A Modern Guide to Union Prevention (1998). ${ }^{125}$ Anne Kubek, Union Awareness Training for Borders Managers: Confidential Property of Borders Inc., September 1996, republished by the Industrial Workers of the World, last modified August 5, 1998, http://parsons.iww.org/ borders/manual.html, Internet Archive, accessed May 27, 2016, https://web.archive.org/web/20010815060549/http://parsons.iww.org/ borders/manual.html.

${ }^{126}$ Jane Slaughter, “Can Selling Books Ever Be a 'Good Job’?” Labor Notes, November 1997, 3.
} 
that he and his fellow coworkers were paid less than the average retail worker and that their "job is more demanding intellectually and sometimes physically." 127

Wesley Gibbs, a thirty-year-old Indiana University graduate with an English degree working at the Louisville, Kentucky Barnes \& Noble store \#2705, began organizing in August 1997 after learning about the Borders union campaigns. When questioned by management about his actions, Gibbs stated that he "felt that it was my obligation as a United States citizen to improve working conditions which ultimately affects workers around the world." ${ }^{128}$ Gibbs reported that the Borders union websites inspired him to launch http://booksellersunion.org/ to encourage the unionization of Barnes \& Noble's employees. The site republished financial information about the company and top executives from the Securities and Exchange Commission's website, as well as included forums and discussion boards, creating a horizontal communication network between employees from Barnes \& Noble and Borders. In less than four months, Gibbs received forty messages from current employees at thirty different store locations and tallied 6,300 views. ${ }^{129}$ Summarizing just how technologically far ahead nonunionized retail book clerks were compared to the UFCW, the largest union representing retail workers in the country, Local 227 organizer Bruce Finley acknowledged that the internet was an "untapped resource" for the labor movement, one that "kind of takes the isolation away" from workers in organizing campaigns. Additionally, as Courier-Journal

\footnotetext{
127 Tamara Chuang, "Barnes \& Noble Employees Consider Unionizing Store,” Arlington Morning News, October 25, 1997, accessed May 26, 2016, http://booksellersunion.org/arlingto.htm.

${ }^{128}$ USNLRB Case 9-CA-35548, Affidavit, http://booksellersunion.org/affidavit.html, Internet Archive, accessed May 27, 2016, https://web.archive.org/web/20160115071847/http://booksellersunion.org/affidavit.html. ${ }^{129}$ USNLRB Case 9-CA-35548, Internet Archive, https://web.archive.org/web/20160115071847/http://booksellersunion.org/affidavit.html.
} 
reporter Joe Ward summarized, "Workers far apart can use it to share ideas and to give each other emotional support. They also can benefit from the same research on the company, much of which can now be done on the Internet." ${ }^{\prime 130}$ Although Barnes \& Noble's employees in Kansas City, Missouri and Charlottesville, Virginia, joined the Arlington and Louisville workers by trying to unionize with the UFCW in the late 1990s, none of the campaigns succeeded in achieving recognition or collective bargaining agreements.

The arrival of Amazon.com in 1995 further disrupted the retail triangle that historically existed under capitalism between the employer, the employee, and the consumer. By creating a global digital marketplace for books, Amazon.com founder Jeff Bezos eliminated the face-to-face interaction from the transaction and shifted the expected skill set of the employee from literary knowledge to technical support. Union activists around the globe anticipated the importance of organizing Amazon's operation during its early phases and launched an international effort to organize its customer service and distributions centers in November 2000. In the United States, WashTech (an initiative of Communication Workers of America) targeted the four hundred Seattle based customer service associates, while a partnership between the UFCW and the Prewitt Organizing Fund (POF) sought to organize five thousand workers at seven distribution centers around the country. POF served as an incubator for organizers and campaigns as a non-profit and independent labor group that partnered with established unions. Yet, the UFCW broke with POF over disagreements, including POF's support for

\footnotetext{
${ }^{130}$ Joe Ward, "Internet Helps Drive to Organize Bookstore Labor," The Courier-Journal, January 20, 1998, Business Section, 1.
} 
Ralph Nader's presidential campaign, just as organizers prepared to publicly launch the campaign, a series of events that doomed the union drive in the distribution centers. ${ }^{131}$ Amazon responded to WashTech's customer service campaign aggressively, calling a paid "all hands meeting" with less than a twenty-four hour' notice. Union activists considered it a captive audience meeting because of the short notice and the previous precedent that all hands meetings were voluntary and not paid. Management later expelled workers from the breakroom when they attempted to discuss the union effort with groups of coworkers. Additionally, Amazon created and directed its associates to an "informative and educational" FAQ web page the firm created about unions, illustrating that companies could also utilize the internet to counter organize the workforce. ${ }^{132}$ Though these domestic organizing efforts failed to gain recognition or collective bargaining agreements, the setbacks and small successes illustrated two conclusions. First, despite all the rhetoric regarding the "new economy" and its liberal values, which made unions irrelevant, WashTech co-founder Marcus Courtney noticed only a superficial difference between how management within the traditional and new economies responded to workers' collective activity. "Management is completely willing to accept someone with a nose ring," remarked Courtney of Amazon, "but all of a sudden that employee with a nose ring wants a real say over how things are going, they think it's

\footnotetext{
${ }^{131}$ David Moberg, “Amazon Workers on the Move," In These Times, January 8, 2001, http://www.inthesetimes.com/web2503/moberg2503a.html, Internet Archive, accessed May 27, 2016, https://web.archive.org/web/20010128051800/http://www.inthesetimes.com/web2503/moberg2503a.html.

132 Troy Wolverton, "Union Organizers Criticize Amazon FAQ," C-NET News.com, December 29, 2000, http://news.cnet.com/news/0-1007-200-4305286.html, Internet Archive, accessed May 27, 2016, https://web.archive.org/web/20011130031330/http://news.cnet.com/news/0-1007-200-4305286.html; "Day 2 Rebuttal to Amazon.com Management's FAQ," last modified December 28, 2000, http://www.washtech.org/day2/122800_rebuttal.html, Internet Archive, accessed May 27, 2016, https://web.archive.org/web/20010408025647/http://www.washtech.org/day2/122800_rebuttal.html.
} 
1910 all over again." ${ }^{133}$ Next, despite the labor movement's five years of resurgence, WashTech organizers Gretchen Wilson and Mike Blain challenged the narrow vision of membership most unions held, arguing that continual evaluation of a campaign's success based on the acquisition of a contract "is a shortsighted and outmoded yardstick." ${ }^{134}$ At the start of the twenty-first century the WashTech organizers were not alone with their criticisms, as progressives and radical unionists increasingly experimented with tactics outside the contract model. Wilson and Blain argued that the reliance on contracts benefited employers, prevented unions from gaining new members, and was "symptomatic of a shrinking and nostalgic U.S. labor movement."135

\section{History of Book Selling in Portland and Powell's Books}

Portland, founded in the Oregon Territory on the Willamette River in 1845, maintained multiple bookstores within a decade of existence, thanks to entrepreneurial retailers and printers. Early Portland settler and regional merchant Stephen Coffin began advertising his "small assortment" of books and stationery for sale in 1850, a year later opening a general store on Washington and Front Streets that featured school books. ${ }^{136}$ Another successful early Portland bookseller was Stephen J. McCormick, a printer and publisher who sold his titles at his Franklin Book Store on Front Street. ${ }^{137}$ Opened in 1852 , it quite possibly was Portland's first store devoted to books. McCormick’s press,

\footnotetext{
${ }^{133}$ Rachel Konrad, "Union Leader Targets Tech Industry,” C-NET News.com, January 23, 2001, accessed May 26, 2016, http://www.cnet.com/news/union-leader-targets-tech-industry/.

${ }^{134}$ Gretchen Wilson and Mike Blain, "Organizing in the New Economy," WorkingUSA Fall 2001 vol. 5, no. $2,50-51$.

${ }^{135}$ Wilson and Blain, "Organizing in the New Economy," 50-51.

136 "Books and Stationery," Business Notices, Oregonian, December 4, 1850, 4; Gabriel H. Boehmer, City of Readers: The Book Lover's Guide to Portland (Portland, Ore.: Tall Grass Press, 2006), 138-139.

${ }^{137}$ Jeremy Skinner, "Book Publishing," The Oregon Encyclopedia, accessed May 27, 2016, http://www.oregonencyclopedia.org/articles/book_publishing/\#.V0iCbBMrLnA.
} 
which published the work of Joaquin Miller, Abigail Scott Duniway, and popular almanacs, garnered him notoriety as well as positioned him as a political leader, precipitating his selection as a delegate to the state's constitutional convention and election as Portland's tenth mayor. Long before Powell's City of Books, A.R. Shipley opened City Book Store on Morrison Street in 1855. Located within the new post office building, the store boasted that its stock arrived fresh off a steamer from New York, offering both a specialized and general collection of "standard histories, poets, travels, biographies, scientific, and agricultural works" at affordable prices. ${ }^{138}$

Prior to Powell, the name Gill was synonymous to bookselling within Portland and the Pacific Northwest. "There is no better example of steady growth in the bookselling field than J.K Gill company," reported Publishers Weekly in 1920, as its owner employed agents in several states and prepared to break ground on a new eightstory, eight thousand square foot downtown retail space. ${ }^{139}$ Joseph K. Gill began retailing books, along with stationery and office furniture, in Portland in the 1870 s and became the city's foremost name in bookselling by the turn of the century. Gill diversified his financial interests in the 1880 s, becoming a publisher for popular regional works, including the Chinook Jargon dictionary and investing in the Columbia River Paper Co. The J.K. Gill Company began operating out of its headquarters on SW Fifth and SW Alder Avenues in 1922 and at its height operated thirty-six stores in the West. Locally, the company out competed the downtown department stores, such as Meier and Frank, in the 1950s and weathered the rise of suburban shopping centers through the 1960s.

\footnotetext{
138 A.R. Shipley, “City Book Store,” New Advertisements, Morning Oregonian, September 22, 1855.

139 “Gill Company Plans New Building,” Publishers Weekly, June 19, 1920, 1930.
} 
Nevertheless, the Gill family decided to sell their business in 1970 to an out of state firm, which sold it again a decade later before its final owners liquidated the company in 1998. In the 1970s, the number of both single store and chain-operated bookstores in Portland increased rapidly. Yet, the number of used book retailers, such as Cameron's Book Store and Green Dolphin Bookshop, remained few. The category of "Second Hand" bookselling began to enter the city's business directory in 1921, with Hyland's Old Book Store located at 204-206 Fourth Street. Advertising the "largest miscellaneous stock of books in Oregon," the Hyland brothers offered special interest books on such subjects as mechanics and foreign tongues as well as rare titles to downtown shoppers into the 1950s. Although the national chains of B. Dalton's and Waldenbooks arrived to Portland in 1973 and 1982 respectively, the number of independents grew at a faster rate, often specializing in specific fields like feminist, radical, religious, science, or erotic literature. Nevertheless, many of these stores, such as Book Haven and Sandy's Book Nook, followed a national trend of shutting down after only a year or two of operation. ${ }^{140}$ Amidst this proliferation of competition and a decline in downtown retail shopping, Walter Powell opened Powell's Books in 1971 with one hundred boxes of books that he collected at rummage sales and purchased for cash from college students. Walter, a retired contractor and president of the local Ukrainian Orthodox Church, described getting "bit by the book business" while spending a month in Chicago helping his son Michael Powell operate his recently opened used and specialty book shop. By Walter's second year in business, his store boasted 37,000 used paperback and hardcover

\footnotetext{
${ }^{140}$ R.L. Polk \& Co., Portland (Multnomah County, Ore.) City Directory (Kansas City, Mo.: R.L. Polk, 1974-1983).
} 
titles ranging all topics. Although he prided himself as the resident expert of religious books and worked as a teacher prior to becoming a house painter, as a newcomer to bookselling Walter relied on the expert staff he hired for other subjects, including Stefanie Siegel and Bernard M. Kehoe. ${ }^{141}$ Yet, Walter made the decisions on how to retail books, often breaking conventional wisdom. When Walter expanded his business in the late 1970 s to include new books, he aimed to compete with J.K. Gill's by "by adding two of everything and three of nothing," recalled his son Michael. ${ }^{142}$ But, Walter's most successful retail innovation was stocking new and used, paperback and hardcover, next to each other on the same shelves, organized by topic. "I had no sympathy," recalled son Michael at that time still in Chicago, "It seemed crazy."143 No other store had tried and succeeded in organizing books this way, but father Walter's instinct proved "absolutely, brilliantly correct" in hindsight to Michael and the practice became a hallmark of Powell's success. ${ }^{144}$

Walter selected a small, well-worn storefront at 302 SW Twelfth Avenue, one block off the main thoroughfare of West Burnside Street, for the location of his store. The wood floors creaked under the weight of the stacks and shelves of books Walter squeezed into the 1909 space, even having shelves in the bathroom. The area contained an eclectic mix of Portland's working-class and LGBTQ communities, giving the store an instant bohemian quality. The Oregonian's Paul Pintarich fondly recalled being a graduate

\footnotetext{
${ }^{141}$ Velma Clyde, "Religious volumes go fast at Powell's new, used bookshop," Oregonian, August 25, 1979, C9; Obituary, Bernard M. Kehoe, Oregonian, September 19, 1985, E8.

142 Jeremiah Chamberlin, "Inside Indie Bookstores: Powell's Books in Portland, Oregon," Poets \& Writers, March 1, 2010, accessed May 16, 2016, http://www.pw.org/content/inside_indie_bookstores_powell_s_books_in_portland_oregon.

${ }^{143}$ Charles C. Mann, "Volume Business,” Inc, June 17, 1997, 56.

144 John Brant, "How I did It: Michael Powell," Inc, May 2004, 82.
} 
student frequenting Powell's first location. He described the clientele in those early days as being as "used and battered" as the stacks of books Walter piled in every corner of his store. The "denizens of the inner city endlessly seeking esoteric tomes" regularly found Walter behind the counter, ready to direct them to the right book. ${ }^{145}$ Henry Weinhard's brewery on West Burnside Street emitted a consistent smell of cooked malts and hops within an industrial district packed with auto body shops and warehouses, drawing little consumer traffic. Low cost and temporary stay housing buildings resided on the south side of West Burnside Street, including the two floors above the storefront and the Joyce Hotel on SW Eleventh Avenue. A triangle area formed by SW Stark Street and West Burnside Street, between SW Ninth and Thirteenth Avenues, became home to a variety of business owned and frequented by Portland's increasingly public gay community. Gay bars within the triangle, including The Family Zoo and The Majestic Hotel and Bath House, served as centers for socializing and political organization. ${ }^{146}$ Powell's Books and the Majestic, which also reopened in 1971, operated on opposite sides of the street until 1976 when Walter moved his storefront to a bigger ten thousand square foot space one block up, at 1207 West Burnside Street.

Michael Powell joined Powell's Books in 1979, relocating with his wife Alice and new daughter Emily from Chicago at the request of his father who had asked for his help managing and expanding his store. Powell, the great-grandson of an 1890s Oregon homesteader, graduated from Portland's Grant High School in 1958 and received a

\footnotetext{
${ }^{145}$ Paul Pintarich, “Saluting Everyone's Used-Book Store Founder," Northwest Pages, Oregonian, 1985, 16.

146 "1999 Portland Gay History Walking Tour," Gay and Lesbian Archives of the Pacific Northwest, last modified 2011, accessed May 26, 2016, http://www.glapn.org/6045walkingtour.html.
} 
degree in political science from the University of Washington. He spent his summers working as a commercial fisherman, before entering graduate school at the University of Chicago in 1962, hoping to eventually become a professor. While in Chicago in the late 1960s, he began scouring thrift stores and the Maxwell Street flea market for rare books. At first on bike, and later with car, he began buying and transporting books that he could resell on consignment at the university co-op store where he worked. "I enjoyed the treasure hunt of it," recalled Powell fondly of these early days of book scouting. ${ }^{147} \mathrm{He}$ experimented with selling books by catalogue to universities and had hoped to move to Santa Fe, New Mexico to open a store. His friends and professors, including author Saul Bellows and sociologist Morris Janowitz, urged him to turn his passion for rare books into a business venture. When an opportunity arose to share a one thousand square foot store space in Hyde Park, Bellows lent him $\$ 3,000$ to acquire an inventory and, along with other benefactors, helped pay for the initial rent. Despite having no business background, Powell opened shop in 1970 and proved a quick success and a model for father Walter. "I always thought I would come back," Michael Powell recounted in an interview year later about why he left the successful business he started in Chicago, "I always thought of myself as an Oregonian, always kept my Oregon driver's license."148

Michael's return to Portland and the end of Walter's lease on the store's space positioned Powell's Books for a massive expansion in the 1980s. These factors coincided

\footnotetext{
${ }^{147}$ Gail Kinsey Hill, “The Book on Michael Powell," Oregonian, August 15, 1999; Don Hamilton, "Michael Powell: leaving his imprint on Portland," Living, Oregonian, July 5, 1987, 1. On one early occasion, Michael Powell acquired a first edition of Moby Dick for almost nothing at a Chicago auction house in 1971. Powell estimated the book's worth at $\$ 10,000$.

148 Chamberlin, "Inside Indie Bookstores: Powell’s Books in Portland, Oregon,"

http://www.pw.org/content/inside_indie_bookstores_powell_s_books_in_portland_oregon.
} 
with what Michael Powell called "an explosion of reading" in the 1980s, a trend showing increased consumer activity for books. ${ }^{149}$ While the Pacific Northwest responded to the geological explosion of Mount St. Helen's in May 1980, Powell's Books moved into the former American Motors Corporation dealership at 1005 West Burnside Street, immediately sparking speculation of Powell's being the "largest bookstore in the world." ${ }^{150}$ Michael Powell's first of many expansions to the company his father started involved increasing the new location's retail space from 24,000 to 30,000 square feet in 1983. In the first four years of the father-son duo, Powell's sales increased 38 percent with a staff of twenty-four. ${ }^{151}$

As chain competitors B. Dalton's and Waldenbooks expanded aggressively into malls and suburbs in the mid-1980s, Powell's kept pace by opening either a specialized or general book store once a year. "I was both interested in segmenting books like technical and travel and cooking," reflected Michael Powell decades later about expanding his audience of readers, "I was also interested in demographics, like urban centers, suburbs and airports." ${ }^{152}$ In 1984, Powell's opened a store in the neighboring suburb of Beaverton, proving that its new-used retail model could work with the typical chain store oriented suburban consumers. The following year, he partnered with the city of Portland to open a three thousand square foot Travel Store in Pioneer Courthouse Square as well as with business owner and former art gallery proprietor Anne Hughes,

\footnotetext{
${ }^{149}$ Randall Rothenberg, "The Media Business," New York Times, August 12, 1991, accessed May 26, 2015, http://www.nytimes.com/1991/08/12/business/the-media-business-outside-publishing-centers-a-giantbookstore-prospers.html.

150 Geoff Parks, “Book dealers relocate: Sign completes store's move," Oregonian, August 5, 1980 , B2.

151 Julie Tripp, "Where books are big business," Oregonian, August 28, 1983, A22.

${ }^{152}$ Chamberlin, "Inside Indie Bookstores,"

http://www.pw.org/content/inside_indie_bookstores_powell_s_books_in_portland_oregon.
} 
who opened a coffee shop in the main store. ${ }^{153}$ Powell's opened its ten-thousand-squarefoot Technical Bookstore near its downtown store and a separate Books for Cooks store, in the trendy Hawthorne District in $1986 .{ }^{154}$ A year later, Powell's opened its Rare Books Room in the main store to showcase two thousand of its highest priced and hard-to-find volumes. ${ }^{155}$ By the end of the decade, Powell's maintained seven locations, including one within the concourse of Portland's airport. As a destination for locals and tourists alike, Powell's had become more than a bookstore but a destination. "It sounds like it was planned," Michael Powell said about the decisions and speed of Powell's expansion in the 1980s, "but it wasn’t. It was just opportunity and impulse."156

Powell's success has historically rested on its entrepreneurial approach to used book dealing, particularly its aggressive acquisition strategy. Both father and son shared the emphasis on book buying. Walter explained his approach in 1979, "Our advertising is all slanted toward buying books. Once we have them, we can sell them," he once explained. ${ }^{157}$ Shortly after joining the company, son Michael echoed his father's sentiments, emphasizing their focus was "on buying books, not selling." He observed, "If we can get a really good quality book, we know we can sell it with no trouble at all."158

\footnotetext{
${ }^{153}$ Suzanne Mantell, "Michael Powell: His customers are looking for the unusual," Publishers Weekly, January 26, 1998, 4; Michael Wade, "Square to unveil store for people going places," Oregonian, November 29, 1985 , E4.

${ }^{154}$ Ken Hamburg, "Powell's Books opens pages to untapped market in Pacific," Oregonian, November 19, 1986, F8; Randall Rothenberg, "The Media Business," New York Times, August 12, 1991, accessed May 26, 2015, http://www.nytimes.com/1991/08/12/business/the-media-business-outside-publishing-centers-agiant-bookstore-prospers.html. Powell's Technical Store located at 33 Northwest Park Avenue.

${ }_{155}$ Paul Pintarich, "Powell's sets aside space for the rare," Oregonian, March 15, 1987, 18.

${ }^{156}$ Chamberlin, "Inside Indie Bookstores," http://www.pw.org/content/inside indie bookstores_powell_s books in_portland_oregon. 157 Velma Clyde, "Religious volumes go fast at Powell's new, used bookshop," Oregonian, August 25, 1979, C9.

${ }^{158}$ Geoff Parks, "Book dealers relocate: Sign completes store's move," Oregonian, August 5, 1980, B2.
} 
By 1998 , the company was purchasing 3,500 books over the counter each day. ${ }^{159}$

Additionally, in an era of bookselling where the perception that bookstores either had to specialize or generalize to meet the customer's needs, Powell's did both on a scale that precipitated the superstores of later decades. Nevertheless, the personalities and business approaches of father and son revealed significant differences, each contributing to the success and character of the store. Although Walter continued to work behind the counter up until his death in 1985, he had sold the store to Michael in 1982. "It was like Old and New world capitalism," said Stefanie Siegel to the Oregonian in 1999, who began working at Powell's in 1971. While Walter gave Powell's an innovative retailing strategy and the charming 'Pop' of a local small business, Alice Powell, attributed the "magnitude" of the store to her husband Michael, who some employees found distant and preoccupied with making deals. ${ }^{160}$

Michael Powell proved an adept entrepreneur in both used book buying and selling. In order to satisfy the demand for used books of his Portland customers, Powell's needed a supply line beyond its reach in the metropolitan region. When independent bookstores go out of business, their remaining stock is often sold at discount to other local independents, effectively keeping that revenue stream local. Powell capitalized on the closure of independent bookstores nationally by acquiring their remaining stock at bargain prices, as was the case with a Cleveland, Ohio bookseller in 1983. Powell purchased 700,000 books for $\$ 300,000$ dollars, spurring the need for the 1983 store expansion. ${ }^{161}$ Again, in 1990s he purchased the remaining fifty thousand volumes from a

\footnotetext{
${ }^{159}$ John Balzar, “A Novel Method to Sell Books,” LA Times, August 7, 1998.

${ }^{160}$ Kinsey Hill, "The Book on Michael Powell."

161 Tripp, "Where books are big business," A22.
} 
Bloomington, Indiana dealer going out of business. ${ }^{162}$ Additionally, collectors sought out Powell's Books to liquidate their personal libraries, including one seller in Maryland from whom Michael Powell bought twenty thousand books in 1999. ${ }^{163}$

Michael Powell simultaneously positioned his bookstore as an industry leader globally through unparalleled partnerships with nation-states, such as Vietnam, and domestically through application of innovative merchandising practices. Powell sought out transpacific opportunities to deal books in bulk during the mid-1980s, finding new markets and a growing demand for English language paperbacks, technical books, and magazines in the Philippines, Korea, China, and Japan. ${ }^{164}$ Powell's became the first commercial trade partner to Vietnam since the 1975 embargo, brokering a deal with the country's Ministry of Culture in 1992 for English language textbooks, paperback fiction, and technical manuals. ${ }^{165}$ Meanwhile, Powell's stores provided local customers with a hyper-organized book arrangement in which the main store was divided into color coded rooms, further divided into labeled sections with identifiable subsections in every aisle. Powell continued his father's innovative and popular practice of shelving new and used books alongside one another. Powell's introduced shopping baskets and full-color maps at store entrances, facilitating a consumer experience that merged the excitement of a treasure hunt with the satiation of buying in bulk. Employees stationed at information

\footnotetext{
162 John Balzar, "A Novel Method to Sell Books," LA Times, August 7, 1998.

${ }^{163}$ C-SPAN 2, "Powell's City of Books," Book TV, filmed February 27, 1999, accessed January 7, 2017, https://www.c-span.org/video/?120959-1/powells-city-books.

${ }^{164}$ Hamburg, "Powell's Books opens pages to untapped market in Pacific," F8.

${ }^{165}$ Marnie McPhee, "Booking to Vietnam," Oregon Business, December 1994, 96; "Powell's Books: First U.S. Commercial Exports to Vietnam Depart from Port of Portland; \$50,000 Order Includes College Textbooks," PR Newswire, June 30, 1992.
} 
desks in each room provided expert, no-hassle customer service in case shoppers required extra assistance with the store's self-guided design.

The bookstore's success in the 1980s garnered Powell city-wide praise and he became a leading voice from the business community within civic affairs. In 1987, Powell donated to the county library's new Black Resource Center in North Portland a collection of three hundred books written by black authors dating back to the early nineteenth century. The Fisk University Press Reprint series, valued at $\$ 5,000$, became the backbone of the collection. Later that year, Powell partnered with the Black Resource Center by donating 250 books to a holiday "Books for Kids" giveaway. 166 "He has a social conscience that most of us should have," stated Portland's populist mayor Bud Clark that year. ${ }^{167}$ When funding for school libraries was equalized statewide in 1994 , cutting the budgets of Portland's school districts, Powell's initiated the "It's for Kids" charitable campaign. The effort raised tens of thousands of dollars for area school libraries each year, distributed to schools through gift cards to Powell's. ${ }^{168}$ The bookstore owner also has been involved in a long list of philanthropic, arts, cultural, and civic organizations, including Portland's World Affairs Council, Chamber Music Northwest, the Northwest Triangle Association, and many more since the 1980s. ${ }^{169}$

Powell publicly contributed to liberal causes that aligned to his political outlook as a supporter of the Democratic Party and his position as a business figure. Powell's

\footnotetext{
${ }^{166}$ Suzanne Richards, "Early Black Literature to Stock Library Shelves for Opening of Center," Oregonian, March 1, 1987. 4M; David Austin, “'Books for Kids' Response Overwhelming,” Oregonian, December 20, 1987, F1.

${ }^{167}$ Don Hamilton, “Michael Powell: Leaving His Imprint on Portland," Living, Oregonian, July 5, 1987, 1. ${ }^{168}$ Andrea Glick, "Portland, OR, Bookstore Shares Profits with School Libraries" School Library Journal March 1998 Vol 44, 3 p. 97; Steven M. Zeitchik, "Powell's Extends a Helping Hand to Area Libraries" Publishers Weekly; January 12, 1998, 22.

${ }^{169}$ Hamilton, "Michael Powell: Leaving His Imprint on Portland," 1.
} 
Books benefited from the shop local movement, a liberal consumer response to the conglomeration of national retail chains that drew money out of the local economy. In a display of solidarity with his competitors, Michael Powell, often posted a large "BREAK THE CHAIN" sign in his downtown store's windows with a list of Portland's independent bookstores. ${ }^{170}$ When the controversial Ballot Measure 9 initiative sought to amend the state's constitution to discriminate against the LGBTQ community in 1992, Powell's Books joined other business and cultural leaders by contributing $\$ 10,450$ to the coalition opposing the measure. "Nine could be the most devastating thing to happen to our economy in our time," Michael Powell told an oppositional rally of ten thousand attendees at Portland's Pioneer Square, forewarning that it could lead to a national boycott of Oregon businesses. During censorship and book banning episodes, bookselling became a defiant political act. "We have a social responsibility to the community and our industry to fight censorship," declared Powell's website in October 1999. ${ }^{171}$ When Congress attempted to regulate internet content in the late nineties through the Child Online Privacy Act, Powell's joined sixteen other plaintiffs represented by the American Civil Liberties Union (ACLU) to challenge the law. "Powell's is proud to join forces with these other organizations to translate our values into actions," stated a letter to customers in April 1999. Such examples of Michael Powell's engagement and leadership in the community won him an appointment by Democratic Governor John Kitzhaber to serve as a Port of Portland Commissioner for two terms in the 1990s. The influential position in

\footnotetext{
${ }^{170}$ Pat Holt, “The Pacific Northwest, Part II, Powell's: Trouble in Paradise," Holt Uncensored \#49, March 30, 1999, http://www.holtuncensored.com/members/column49.html.

${ }^{171}$ Powell's Books, "The Child Online Protection Act," http://www.powells.com/cdatoo.html, Internet Archive, accessed January 17, 2017, https://web.archive.org/web/19991012192033/http://www.powells.com/cdatoo.html.
} 
the region's economy, trade, and labor relations brought Powell in direct contact with several unions representing workers at Portland's docks and airport. For his service, Powell won the praise of the Portland Business Journal editorial board who commented that he "studies the shipyard and asks tough questions of the folks who run the port. [...] That's why we need to keep him on the commission." 172

For Powell's, the 1990s began with optimism and a continuation of growth and ended with the unexpected unionization of its workforce. Nevertheless, the proliferation of chain superstores and the arrival of internet bookselling made for a challenging decade for independent bookstores nationwide, resulting in the closure of many stores and further consolidation of the sector. Powell's responded to its growing competition by expanding four locations by 5,000 to 10,000 square feet, including the main store that now contained 43,000 square feet. ${ }^{173}$ Additionally, a new general bookstore next to its cookbooks store was added on SE Hawthorne Boulevard in the mid-1990s. The company also experimented with a variety of specialized stores during this growth period, including a Powell's Books for Health located in a Portland hospital, a Powell's Books for Kids in Beaverton, an audio book store, and a calendar store in a mall. In 1998, the Hawthorne culinary book outlet broadened its specialization and became Books for Cooks and Gardeners. ${ }^{174}$ Competition for new book sales at this time shifted from B. Dalton's and Waldenbooks, to the superstores of Barnes \& Noble and Borders. While

172 “Punishing Powell,” Portland Business Journal, October 12, 1997, accessed May 27, 2016,
http://www.bizjournals.com/portland/stories/1997/10/13/editorial1.html.
173 Angel, “Are Independents Making a Comeback?” 22.
174 U.S. West Dex, Inc, The Yellow Pages Portland (Englewood, Colorado: U.S. West Dex, 1998). 
Barnes \& Noble targeted suburbs and shopping center, Borders competed directly with Powell's for downtown sales by opening a location on SW Third Avenue in 1996.

Powell's transition from a paper to a computerized sales and inventory system proved difficult, but resulted in a systematic consolidation of information that improved the company's used book buying performance and allowed it to enter the digital marketplace. Powell's was a pioneer in internet book sales, recording its first sale through a telnet to an Apple employee in 1993. ${ }^{175}$ Powell's Books entered the digital marketplace in 1994 through the initiative of a single employee and a $\$ 10,000$ company investment, a year before Amazon.com went online. By 2000, Powell's collected half million dollars through its online sales, netting thirty-thousand visitors and a thousand buyers each day. ${ }^{176}$ All this with an internet staff of only forty-nine employees, far smaller than its Seattle-based competitor Amazon. Michael Powell recalled that the impetus came from local competition by the national chains: "At the time, Barnes \& Noble and Borders were opening stores all around me. My wagons were circled and they attacked from the suburbs, these giant stores. And I thought, 'If there's any way to leap over those stores and reach a broader audience, there's nothing better than this thing called the Internet." ${ }^{177}$ Nevertheless, unlike its chain competitors, Powell's still used a manual system of inventory cards to track its sales. Creating a database of the store's collection

\footnotetext{
175 David Raths, "Powell's Books Finds New Clients on the Net," Puget Sound Business Journal, November 13, $1998,9$.

176 Adam L. Penenberg, “Crossing Amazon,” Forbes, April 17, 2000, accessed September 6, 2017, https://www.forbes.com/forbes/2000/0417/6509168a.html.

177 Chamberlin, "Inside Indie Bookstores: Powell's Books in Portland, Oregon," http://www.pw.org/content/inside_indie_bookstores_powell_s_books_in_portland_oregon.
} 
took a full year, but by 1996 Powells.com featured the store's inventory, tallying $\$ 1.5$ million in sales a year later and reaching $\$ 10$ million in $2000 .{ }^{178}$

By the late 1990s, Powell's bookstore had become known as the city's unofficial living room, a social and cultural destination whose owner reaped both social and financial capital. As the company's profitability rose 10 percent in 1997, the press called Michael Powell "one of Portland's city fathers," a figure whose business became an anchor for urban commercial and residential development. ${ }^{179}$ "Powell and his books make Portland a better place in which to live," declared the Oregonian. ${ }^{180}$ Nevertheless, increased competition from national chains and a burgeoning digital marketplace threatened the prized local store's profitability. Surveying the national landscape in August 1998, Michael Powell described the moment as the "most critical phase in the history of American book selling." 181 The retail book sector appeared on a precipice, and industry experts observed that "Powell's is simultaneously specialized and diversified, giving it a rare advantage in a ruthless market that rewards both qualities." ${ }^{182}$ Earlier that year, Powell's management embarked upon an ambitious expansion plan to secure its place locally and globally, while also restructuring the labor process. Consequently, the rapid changes that occurred internally at Powell's, externally in the retail book sector, and nationally within the labor force converged in the summer of 1998, when Powell's

\footnotetext{
${ }^{178}$ Raths, "Powell's Books finds new clients on the Net," 9; Penenberg, "Crossing Amazon," https://www.forbes.com/forbes/2000/0417/6509168a.html.

${ }^{179}$ Balzar, "A Novel Method to Sell Books."

${ }^{180}$ Hamilton, "Michael Powell: Leaving His Imprint on Portland," 1.

${ }^{181}$ Balzar, "A Novel Method to Sell Books."

182 Angel, “Are Independents Making a Comeback?” 22.
} 
bookstore employees chose to challenge these conditions through a union campaign, which became a public affair for nearly two years. 


\section{Chapter 3}

\section{Booksellers and Dockworkers: Organizing the Union at Powell's Books (September 1998 - April 1999)}

\section{The Powell's Employees' Association and Oregon Public Employees Union Drive}

Employees at Powell's Books twice attempted to organize themselves in the decade prior to the 1998 ILWU union drive, confronting management collectively and demanding a voice in the company's decisions. The booksellers' first attempt was not explicitly a union drive, rather it was a self-organized committee of workers that identified as the Powell's Employees' Association. The loosely organized representative body formed in 1987 among employees at the Burnside location. Jeff Hensley, who began working at the store in 1984, and several other fellow association members held a series of meetings with management over the course of a year to recommend improvements on how the company communicated with staff about its changing and growing operation. The association proved short-lived, but appeared to have influenced Michael Powell's decision to formalize the responsibilities of employee communication and hire a Human Resources manager.

The first unsuccessful effort for union recognition at Powell's Books came following the 1990 holiday shopping season. Powell's management had anticipated a prosperous holiday season, hiring a crew of new workers to prepare for the expected increase in customers and sales. However, snow, ice, and frigid temperatures dropping into the teens devastated holiday sales expectations. Managers informed staff of imminent layoffs beginning in January, the first in the company's history. Employees expected that the bookstore would respect the seniority of workers who had been with the company for several years. When management delivered the two dozen layoff notices to 
store employee's mailboxes, however, workers decried the company's decision to let go several veteran staff members and retain workers hired only a few months earlier, calling it "The Christmas Massacre." 183 An employee association from the main store, where the majority of layoffs occurred, met in the aftermath and decided to unionize. The organizing committee ultimately decided upon the Oregon Public Employees Union (OPEU) as its bargaining agent. ${ }^{184}$ By the summer of 1991, union activists and OPEU organizers made significant progress outreaching to workers in the main store, but fell short of demonstrating a commanding majority believed necessary to win a union election.

The OPEU's effort to expand into the private sector proved a failure because of its service model approach with union activists and a lack of support company wide. Hensley described a "clash of cultures," believing that the environment of Powell's Books differed significantly from the public-sector workplace. In hindsight, the veteran bookseller thought that the OPEU underestimated "how much work it would take to reconcile everybody" to union life. ${ }^{185}$ With limited space for involvement from Powell's employees, Hensley noted that it appeared organizers were inclined "to do too many things for us." ${ }^{186}$ In practice, this service model approach and professionalization of

\footnotetext{
${ }^{183}$ Kristen Russ, "No Decisions About Us Without Us: A History of a Bookstore Union," No Decisions About Us Without Us: History of Local 5 - Powell's Books, ILWU Local 5, accessed December 28, 2016, http://ilwulocal5.com/?page id=46.

${ }_{184}$ The Oregon Public Employees Union (OPEU), originally established as the Oregon State Employees Association (OSEA) in 1943, affiliated with the Service Employees International Union (SEIU) in 1980. 185 Jeff Hensley, interviewed by Edward Beechert, Local 5 Oral History Project, Anne Rand Library, International Longshore and Warehouse Union, San Francisco Calif. (hereinafter ILWU Library), November 19, 2001, 4.

${ }^{186}$ Emphasis included by Beechert. Hensley, Local 5 Oral History Project, 3. "But I do feel that they--there was a bit much of 'we'll do this for you and we'll that for you and later on you folks can get trained and get up to speed on how to do these things.' And personally, I don't think that was a good idea at the time because it meant that there was a bit more of the idea that these folks will take care of us. Not that they
} 
union organizing prioritized the role of union staff over rank-and-file leadership. Further hampering the campaign was the OPEU's decision to only organize the main store and, forego outreaching to the satellite stores. Powell's responded to the drive with measured reservation, issuing a few company memos that recognized that the company was experiencing some growing pains. In a letter to the ILWU organizing committee in 1998, former bookseller and union supporter Wayne Pernu noted a "real divisiveness among employees" regarding unionization, which negatively impacted the organizing drive and which management had no significant role in instigating. ${ }^{187}$ Even though the union collected over 30 percent of signed union authorization cards from booksellers (significantly less than the goal of 65 percent), the union decided to end its organizing efforts in July 1991.

Despite the unionization defeat, the organizing committee successfully compelled Powell's corporate management to make modest reforms. Managers hoped to demonstrate through these reforms that the OPEU's union campaign was unwarranted. At the campaign's conclusion, union activists presented Michael Powell with what they called a "Justice Doctrine," which called for such reforms as a consistent wage policy, clear job descriptions, and a grievance procedure. Additionally, the letter encouraged Powell himself to increase the responsibilities of employees and create more communication channels between managers and booksellers. ${ }^{188}$ Although OPEU

\footnotetext{
didn't, it's just that the folks at the Beaverton store and the other stores didn't feel particularly involved. There weren't as many ways to sort of get involved..."

${ }^{187}$ Wayne Pernu, letter to union organizing committee, Local 5 Oral History Project, ILWU Library, ILWU Local 5 Document Archive, "What did occur eight years ago which management had little control over was a real divisiveness among employees, which manifested itself in the form of nasty daybook comments $[\ldots]$ and a general bad feeling amongst employees with differing views." ${ }^{188}$ Russ, "No Decisions About Us Without Us: A History of a Bookstore Union," http://ilwulocal5.com/?page_id=46.
} 
organizer Jean Eilers recalled Powell reacting harshly to the letter presented to him, the company did institute a number of changes that seemed to respond to employees' concerns, including an updated employee handbook in April 1992 that added a Problem Solving Process and procedures for termination. ${ }^{189}$ Nevertheless, many of the disheartened worker-organizers left the company when the union campaign folded.

The third, and ultimately successful, 1998 organizing campaign began with informal discussions among workers about the possibilities of unionization, preparing workers to act when conditions for unionizing were most ripe. Mary Winzig, John McMahon, and Marty Kruse -three employees who emerged as early leaders of the organizing drive and who started with the company in the mid-nineties-all discussed unionizing with trusted coworkers periodically but neither took further action. "We just felt like our jobs were being pulled away. We felt like we didn't have any control," recalled Winzig about the sentiment of her early conversations. When filmmaker, author, and public proponent for the Borders union Michael Moore visited the store in 1997, Winzig approached him for advice on unionizing but later recalled that the process seemed too daunting to undertake. ${ }^{190}$ However, by the summer of 1998 a rapid sequence of management initiatives compelled workers to act. For McMahon who started at Powell's in 1996 these changes to working conditions in summer of 1998 polarized the options in his mind, either "quit or do something about it."191

\footnotetext{
189 Don McIntosh, "Powell's Books Trying to Stifle Organizing Drive by ILWU," Northwest Labor Press, December 18, 1998, accessed January 7, 2017, https://nwlaborpress.org/1998/12-18-98Powells.html. ${ }^{190}$ Mary Winzig, interviewed by Harvey Schwartz, ILWU Oral History Collection, ILWU Library, June 11, 2001, Tape 1, 16.

191 John McMahon, Local 5 Oral History Project, 2. John McMahon, interviewed by Edward Beechert, Local 5 Oral History Project, ILWU Library, November 19, 2001, 2.
} 
The 1998 union drive at Powell's Books arose from a convergence of precipitating and immediate factors, not dissimilar from those that typically spur organizing campaigns in other workplaces. Workers expressed concern about the increasing distance managers placed between themselves and front-line staff. "Management really just pulled themselves away, and had not a lot of personal relationships with what was going on," recalled Winzig, adding that management was "so out of touch" that it benefitted the union campaign. ${ }^{192}$ The autonomy of employees to maintain their own work hours and job responsibilities became an area of contest where management proved determined to invoke its authority. A previous culture of flexible scheduling, in which workers could arrive late or early without reprimand so long as employees completed their hours and work tasks, became subject of increased scrutiny by managers in what workers described as a more "corporate atmosphere."193

The immediate factors for the union drive included a series of initiatives forwarded by upper management aimed at aggressively expanding the physical space of the store, centralizing knowledge of work processes, and curtailing labor costs. Although the region's labor market in the late nineties appeared advantageous for union organizers for its low unemployment, Powell's did not have difficulty attracting applicants. The ILWU campaign (September 1998 through August 2000) occurred during a period of low unemployment in the Portland metropolitan area, not exceeding 4.9 percent and reaching a low of 3.7 percent in December 1999. ${ }^{194}$ Nevertheless, General Manager Miriam Sontz,

\footnotetext{
192 Winzig, ILWU Oral History Collection, Tape 1, 12.

${ }^{193}$ Winzig, ILWU Oral History Collection, Tape 1, 14.

${ }^{194}$ U.S. Bureau of Labor Statistics, Unemployment Rate in Portland-Vancouver-Hillsboro, OR-WA (MSA) [PORT941URN], retrieved from FRED, Federal Reserve Bank of St. Louis, accessed December 26, 2016 https://fred.stlouisfed.org/series/PORT941URN.
} 
who previously worked at J.K. Gill for seven years before joining Powell's in 1980s, reported that a job opening typically received anywhere from twenty-five to one hundred applicants. ${ }^{195}$ In explaining why Powell's employees chose to organize and, furthermore, proved successful in a prolonged dispute while most workers, particularly retail workers, have failed to unionize, Winzig believed that timing was the key factor. "Management pulled so many things all at once," she explained, "we had the momentum and the anger that was able to sustain us."196

In 1998, Powell's Books embarked upon an ambitious expansion of both its digital and physical presence to remain competitive on the growing internet and local marketplaces. Already, Powell's maintained a reputation as the biggest independent bookstore in the country and likely the largest physical bookstore in the world. With nearly a million books on the shelves within a building that occupied an entire city block, Michael Powell compared his latest expansion plans to a high stakes wager: "It's a bet on readers. It's a bet on books. It's my bet, and I'm betting I can do it." ${ }^{197}$ Two building expansions planned to increase the size of the main store to 73,000 square feet, a 60 percent increase in retail floor space that also included a new event space ten times the size of its predecessor. ${ }^{198}$ The first project broke ground in July 1998, followed by a three-floor expansion upward (known internally as "The Tower") slated for completion by November 1999. An expanded space for the internet sales department accompanied a

${ }^{195}$ C-SPAN 2, "Powell's City of Books," Book TV, filmed February 27, 1999, accessed January 7, 2017, https://www.c-span.org/video/?120959-1/powells-city-books.

${ }^{196}$ Winzig, ILWU Oral History Collection, Tape 1, 10.

197 John Balzar, “A Novel Method to Sell Books," LA Times, August 7, 1998.

${ }^{198}$ Karen Angel, "Powell's Books Pushes Back Its Boundaries, Both Physical and Virtual," Publishers Weekly, August 10, 1998, 243; John Balzar, "A Novel Method to Sell Books," Los Angeles Times, August 7, 1998. 
push to compete with Amazon and Barnes \& Noble for web sales. Rather than generating confidence in the company's success and future, this $\$ 3.5$ million expansion plan to the City of Books created uncertainty among employees regarding how the company could afford such plans during a period of increased competition from superstores while at the same time maintaining workers' wages, benefits, and the store's fiercely independent culture. ${ }^{199}$

On the heels of the physical restructuring of the City of Books came a realignment of work operations that appeared to threaten the long-held power and responsibilities of booksellers. Powell's employee Nancy Sturken recalled what she considered a disingenuous attempt by management to get staff input on the restructuring, creating a handpicked committee to offer feedback and then introducing the plan with miniscule alteration. ${ }^{200}$ In the summer of 1998 , the company informed employees about a restructuring of operations that affected how sections were staffed, instituting a new "team" system, which centralized the power of book buying. Workers, particularly the one hundred section heads with the responsibility of ordering books, expressed their disapproval with this "Great Restructuring" in terms of power, skill deprivation, and an inability to provide customer service at the level expected by the store's clientele. ${ }^{201}$ "My

\footnotetext{
${ }^{199}$ Jim Cowing, interviewed by Edward Beechert, Local 5 Oral History Project, ILWU Library, August 28, 2001, 7; John Balzar, “A Novel Method to Sell Books," Los Angeles Times, August 7, 1998: “'It's a bet' says Powell. 'It's a bet on readers. It's a bet on books. It's my bet, and I'm betting I can do it . . if this piece of culture goes down, I'll go down with it."”

${ }^{200}$ Russ, "No Decisions About Us Without Us: A History of a Bookstore Union," http://ilwulocal5.com/?page id=46.

${ }^{201}$ Pat Holt, "The Pacific Northwest Part II Powell's: Trouble in Paradise," Holt Uncensored, Issue \#49, March 30, 1999, accessed December 26, 2016, http://holtuncensored.com/members/column49.html; "Workers at Powell's Books Organize for Their Future - And Ours" leaflet, ILWU Library, ILWU Local 5 Document Archive, June 2000.
} 
job was seriously reorganized," recalled bookseller Mary Zartman, "which is a nice way of saying that it was dis-empowered, discombobulated, and it was a disgrace."202

The restructuring of the labor process resulted in employees with specialized knowledge accustomed to working in specific sections being assigned duties in amalgamated section teams regardless of experience or familiarity with the subject matter. "It felt like a 'dumbing-down' of jobs that require a lot of maturity and expertise," explained an anonymous worker. ${ }^{203}$ "We had a lot of autonomy, and they started switching that, and putting us on teams," explained Winzig, who worked in the children's sections with Zartman. Union activists noted that these changes had a much greater agitational effect on Burnside employees than booksellers at any of the satellite stores. Nevertheless, bookseller Jim Cowing argued that Beaverton store employees' disapproval and frustration with an absentee manager acted as an important and generally overlooked factor in motivating the union drive beyond the boundaries of the City of Books. ${ }^{204}$

\section{The "September Surprise" and the Organization of ILWU Local 5}

Management's “September Surprise" targeted workers' expectations for economic advancement and proved the tipping point for their dissatisfaction. On September 14, 1998, an email sent by Corporate Manager Ann Smith titled "Compensation changes" transformed the underlying tension between staff and upper management into the beginning of organized resistance. The email informed employees that the previously announced 6 percent wage increase for all staff, administered in the

\footnotetext{
${ }^{202}$ Mary Zartman, interviewed by Edward Beechert, Local 5 Oral History Project, ILWU Library, April 12, 2002, 1-2.

${ }^{203}$ Holt, "The Pacific Northwest, Part II Powell's: Trouble in Paradise,"

http://holtuncensored.com/members/column49.html.

${ }^{204}$ Cowing, Local 5 Oral History Project, 10-11.
} 
two previous years, required a reduction to 1 to 3 percent. Henceforth, management would determine an individual employee's raise at its sole discretion.

The economic benefits for Powell's booksellers prior to the union campaign surpassed most other non-unionized Portland retail businesses, including Barnes \& Noble and Borders. According to Powell's, the company paid non-management employees an average of \$9.81 per hour along with health insurance, child care, profit sharing, and holiday bonuses that surpassed the industry standard. Conversely, union activists asserted the average was $\$ 7.60$ an hour with new hires beginning at $\$ 7.00$, only fifty cents above the state's minimum wage. ${ }^{205}$ Yet, many Oregon small and independent businesses similar to Powell's Books continued to brood over a successful 1996 ballot initiative that raised the state's minimum wage to one of the highest in the nation, increasing the hourly wage for the state's lowest paid workers by a $\$ 1.75$ between 1996 and $1999 .{ }^{206}$ Simultaneously, two successful 1996 campaigns secured living wage ordinances in both Portland and the wider Multnomah County. ${ }^{207}$ Furthermore, union researchers concluded that while Powell's employed twenty-five managers with annual salaries between $\$ 40,000$ and $\$ 100,000,70$ percent of employees earned less than $\$ 20,000 .^{208}$

Corporate's decision to disband the compensation committee, a grouping of managers and frontline staff organized by Powell's to create recommendations regarding wages and raises, proved an important precursor to the September Surprise. Some

\footnotetext{
205 Gail Kinsey Hill, "Powell's Staff Approves Union," Oregonian, April 23, 1999, C01.

206 State of Oregon, Voters' Pamphlet: Measures, Vol. 1, 95-106, accessed December 26, 2016, http://library.state.or.us/repository/2010/201003011350161/.

${ }^{207}$ Stephanie Luce, Fighting for a Living Wage (Ithaca, N.Y: Cornell University Press, 2004), 219-221;

"Portland City Council Okays New Living Wage," Northwest Labor Press, May 1, 1998, accessed December 28, 2016, https://nwlaborpress.org/1998/wage.html.

208 Marcy Rein, “Organizing by the Book: Powell's Workers Gear Up for Election,” The Dispatcher, March 1999, 3, accessed December 28, 2016, http://archive.ilwu.org/wp-content/uploads/2015/04/19990301.pdf.
} 
employees, including Marty Kruse worked in the small press section of the flagship store, believed that management used the committee as a tool to placate employee demands for input without making any substantive changes. Regardless, Mary Winzig explained that she and other workers throughout the company were affected by upper management's decision to do away with the committee in favor of a subjective top down evaluation. ${ }^{209}$

Kruse began organizing what became the first union meeting immediately following the September Surprise email, effectively ensuring that none of the worker agitation the compensation changes generated could dissipate overnight into resignation. "If you're pissed off, meet at Ringler's Annex 11pm," was the simple instruction scrawled on a piece of cardboard and flashed to coworkers from behind Kruse's coat as he made his nightly rounds through the stacks before the store closed. ${ }^{210}$ During this several hours long informal meeting at Ringler's bar, the union's first leaders emerged and helped guide the generalized discontent of individual workers into concerted resistance and ultimately decision to unionize. Kruse credited bookseller Paul Couey for providing focus to the emotionally charged gathering by advocating for a union and helping "[pull] the whole team together" to determine the next steps for the impassioned workers. $^{211}$

The Powell's Books union drive originated from the initiative and selforganization of the bookstore's employees, setting the course of the campaign on a promising trajectory amidst difficult odds. In the days and weeks that followed the

\footnotetext{
${ }^{209}$ Winzig, ILWU Oral History Collection, 14.

${ }^{210}$ Russ, "No Decisions About Us Without Us: A History of a Bookstore Union," http://ilwulocal5.com/?page_id=46.

${ }^{211}$ Marty Kruse, interviewed by Edward Beechert, Local 5 Oral History Project, ILWU Library, April 20, $2002,3$.
} 
Ringler's meeting, those workers began quietly outreaching to trusted employees and community groups with the intention of building support for a larger meeting of interested staff members. The organizing committee called the local chapter of Jobs with Justice to learn about the unionization process, leading to a series of conversations with the coalition's organizers to identify potential unions for the booksellers to contact for assistance. The worker-organizers also took the unconventional step of inviting representatives from the United Food and Commercial Workers International Union (UFCW), the Industrial Workers of the World (IWW), and the International Brotherhood of Teamsters to attend a meeting with employees interested in unionizing. While union critics might assert that this decision reflected the workers' novice experience with the jurisdictional divisions of the labor movement, historians can also interpret it as an illustration of how the Powell's workers disrupted the traditional power dynamic and positioned themselves in the unconventional position of shopping for a union. Essentially, organizers needed to explain (in the presence of other union representatives) how their union local would support the Powell's workers and what resources they could commit.

The decision to hold a meeting with all interested parties made practical sense because coordinating a single large group meeting proved logistically easier than scheduling a series of meetings with each union representative. Even though this assembly was scheduled for midnight to accommodate those who had closing shifts at the main store, over thirty employees packed into every corner of coworker Audra McCabe's home to hear the union representatives speak. The unusual late-night crowd in the neighborhood prompted a brief visit from the police, adding to the paranoia of some 
workers nervous about unionizing. Similar to Kruse's memory of Paul Couey's informal leadership role at the Ringler's meeting, Winzig recalled that Couey stepped in to help start the meeting to ensure everyone introduced themselves and the reason why they chose to attend. ${ }^{212}$ Even though the IWW and UFCW had a record of organizing bookstores, the meeting ended without firm support for either of the unions. ${ }^{213}$ While many union activists sympathized with the radical ideology of the IWW, workers expressed concern at the Wobblies' limited local resources and the inevitable red-baiting by management if booksellers aligned with an explicitly anti-capitalist labor organization.

In contrast, the International Longshore and Warehouse Union's (ILWU) revitalization of its organizing program under President Brian McWilliams, with its goal of creating a new warehouse local in the Columbia River District, positioned the union to respond wholeheartedly to the Powell's employees interest in unionization. Following the indecisive meeting with the UFCW and IWW, Jobs with Justice organizers encouraged John McMahon to contact the ILWU because of its progressive principles. At an 11:00 p.m. meeting during the first week of October, a delegation of over twenty Powell's employees, including McMahon, Winzig, Kruse, Couey, and Miranda Altman, heard ILWU Regional Organizer Michael Cannarella make the case to organize with the longshore union. During his fifteen years of organizing experience, Cannarella recalled never meeting such a large group of workers at the start of a campaign as he encountered with the Powell's workers that night at ILWU Local 8's offices on NW Front Avenue. "I told them the first night that they had the basis of an organizing committee," stated

\footnotetext{
${ }^{212}$ Winzig, ILWU Oral History Collection, Tape 1, 22.

${ }^{213}$ Although the workers contacted the International Brotherhood of Teamsters early on, a union representative did not attend this meeting.
} 
Cannarella; however, he added that the task would take a lot of work from each of them, but that the ILWU would support them throughout the process. ${ }^{214}$ At the end of the presentation, the workers voted unanimously with a single abstention to join the longshore union and began signing their union authorization cards that night. The workers collectively signed letters stating their intent to organize "because we care about Powell's and feel our contribution is vital to Powell's success." ${ }^{215}$ Cannarella later described the reversal of traditional roles between the workers and the union, explaining that the "[ILWU] didn't choose them, they chose us!"216

While management remained unaware of the union effort during the next several weeks, the organizing committee conducted targeted outreach to Powell's employees with the instructional support of ILWU organizers and local workers' rights organizations. The longshore union began directing staff and material resources to the campaign, including William Kramer who provided the new union with corporate research on their employer. In November, Cannarella assembled an organizer training for union activists to prepare them for the hundreds of necessary conversations required to build and maintain support for the union: "We did role plays," recalled Cannarella, "we talked about how to educate - how to talk to your coworkers" about the union anywhere, whether at a bus stop or in the back shelves. ${ }^{217}$ ILWU organizers described their internal organizing strategy as both a relational and educational campaign. These dual

\footnotetext{
${ }^{214}$ Michael Cannarella, interviewed by Edward Beechert, Local 5 Oral History Project, ILWU Library September 4, 2002, 6 .

${ }^{215}$ Russ, "No Decisions About Us Without Us: A History of a Bookstore Union," http://ilwulocal5.com/?page_id=46.

${ }^{216}$ Cannarella, Local 5 Oral History Project, 4.

${ }^{217}$ Cannarella, Local 5 Oral History Project, 6-7.
} 
considerations meant union activists conducted individual organizing conversations with coworkers by arranging meetings before or after work at nearby coffee shops, bars, or otherwise comfortable and familiar settings. Although leafleting workers outside workplaces and unannounced home visits have long existed as hallmark organizing tactics for unions fighting for employer recognition, the Powell's unionists considered these tactics intrusive to their coworkers. "We had gone to a couple of houses and were totally rebuffed," recalled Winzig about her and John McMahon's effort to outreach to Tech Store workers. "Nobody wanted to talk about unionizing." ${ }^{218}$ After minimal success, the organizing committee transitioned to outreach tactics more in line with the culture of the workplace relying upon one-on-one educational conversations to create space for workers to learn about their rights, successful organizing tactics, and what antiunion responses to expect from employers.

The burgeoning Powell's union's selection of the ILWU as its bargaining agent made sense to the activists on the organizing committee. Jeff Hensley, an early union supporter, discerned a difference between how the ILWU and other union representatives approached the campaign, recalling that the ILWU organizers asked lots of questions about Powell's and stated upfront that the workers needed to take the lead in the campaign. "All the other unions," Hensley recalled, "were like 'we're the cavalry that's going to come over the hill to take care of this for you' and the ILWU is not like that."219 The longshore union's progressive, militant, and democratic traditions appealed to others, including Winzig and McMahon, who saw the Powell's campaign both in a historical and

\footnotetext{
${ }^{218}$ Mary Winzig, interviewed by Edward Beechert, Local 5 Oral History Project, ILWU Library, August 20, 2001, 4; Cowing, Local 5 Oral History Project, 5.

${ }^{219}$ Hensley, Local 5 Oral History Project, 8.
} 
external context. "It made us realize we were linking up with a union with a proud progressive tradition," stated Winzig in a union newsletter in 1999, adding that it "helped us to imagine how we could make ILWU Local 5 a force for progressive change in Portland." ${ }^{220}$ McMahon pointed to the ILWU's long record of taking action for social justice causes, including against apartheid in South Africa, as evidence of the shared values between the union and Powell's employees: "It seems to me that the ILWU has always been at the forefront of progressive issues and this is a progressive workplace."221

The creation of a new ILWU local for the booksellers of Powell's proved advantageous for both the booksellers and the longshore union. While activists stated that the organizing committee selected the ILWU because it offered the new union "the most autonomy" and "seemed the most free and fair," the booksellers' were also motivated by the ability to form a new local. ${ }^{222}$ ILWU Organizing Director Peter Olney clarified that the international decided to charter a new local for the bookstore employees because it aligned with the longshore union's priorities and strategic direction. ${ }^{223}$ Although unaware of the administrative responsibilities associated with operating a local that later arose, the Powell's union activists welcomed the freedom of creating their own local.

Yet, most Powell's employees had no previous experience and little knowledge of the ILWU, leading to surprise, uncertainty, and skepticism among many employees at the start of the campaign. Jim Cowing and Carole Reichstein, booksellers at the Technical

\footnotetext{
${ }^{220}$ ILWU Local 5, Fearless, ILWU Library, ILWU Local 5 Document Archive, February 1999, 4.

${ }^{221}$ McMahon, Local 5 Oral History Project, 3.

${ }^{222}$ ILWU Local 5, “To the Unconvinced...," Fearless, ILWU Library, ILWU Local 5 Document Archive, February 1999, 1.

${ }^{223}$ Peter Olney, interviewed by Harvey Schwartz, Local 5 Oral History Project, ILWU Library, June 3, 2002, 22.
} 
Store, recalled early on not having any reaction to the organizing committee's decision to join the ILWU. Cowing, who started working at Powell's in 1995, believed that the emphasis on creating a new local "seemed like empty rhetoric." 224 Other workers vocally opposed the unionization effort because of the selection of the ILWU. In an open letter to coworkers, Powell's employee Doug Chase stated that he grounded his opposition to the ILWU on news reports of lawsuits filed against the union for discriminatory hiring practices and sexual harassment. "I don't want a portion of my mandatory dues," stated Chase who identified himself as having previously been a member of three different unions, "going to settle someone else's practices, practices which really disgust me and which I think should be punished with far more than what was actually paid." 225 In Winzig's conversations with reluctant coworkers, she interpreted one oppositional trend amongst some employees as a degree of prejudice against dockworkers and unions because of the booksellers' college education. ${ }^{226}$ A union survey conducted in September 1999 revealed that 90 percent of respondents possessed some college education with 58 percent completing a Bachelor's degree. ${ }^{227}$ Therefore, since the workforce was divided on the union question, college experience proved an unreliable indicator of union support or opposition.

\footnotetext{
${ }^{224}$ Cowing, Local 5 Oral History Project, 4; Carole Reichstein, interviewed by Edward Beechert, Local 5 Oral History Project, ILWU Library, April 17, 2002, 3.

${ }^{225}$ Doug Chase, "Why I don't Think This Is a Good Idea Right Now," leaflet, ILWU Library, ILWU Local 5 Document Archive; William W. Pilcher, The Portland Longshoremen: A Dispersed Urban Community (New York: Holt, Rinehart, and Winston, Inc, 1972), 67-76; Harvey Schwartz, Solidarity Stories: An Oral History of the ILWU (Seattle: University of Washington Press, 2009), 39. Doug Chase's criticisms of discriminatory practices of the ILWU were significant in Portland. Despite an influx of black workers into the maritime industry on the West Coast during World War II, Portland's Local 8 excluded black workers and did not begin the process of integration until 1961.

${ }^{226}$ Winzig, ILWU Oral History Collection, Tape 1, 25.

${ }^{227}$ ILWU Local 5, “Survey Says...," ILWU Library, ILWU Local 5 Document Archive, 1999.
} 
The initial Powell's union activists possessed marginal to no formal union experience or familiarity with conducting an organizing campaign, although a larger number expressed support based on previously established principles. While a few booksellers, including Nancy Sturken, Lori Kooyers, and Marc Perry, had direct union experience, Powell's employees more commonly cited tangential experience with unions either from political activism or through an older family member. ${ }^{228}$ Winzig, McMahon, and Ryan Takas cited being from "right-to-work" Southern or Southwestern states as an important factor limiting their exposure to unionism. ${ }^{229}$ Although raised in Texas, Winzig described her Wisconsin born parents as "dyed in the wool Republicans," who nevertheless instructed her to respect and never cross a workers' picket line. While attending the University of Texas in the 1980s, Winzig described being politicized by her involvement in protests against South African apartheid and the policies of the Reagan administration. "I always thought labor was a good idea," attested Winzig, "but I hadn't met any union people until I moved to Portland."230

John McMahon was one of the few union activists with any union organizing experience, having left a job at Tower Books to participate in the AFL-CIO Union Summer program in Seattle in 1996. Earlier that year, McMahon witnessed picket lines outside of Portland Safeway grocery stores during a UFCW strike. "It was the first time I had ever seen one," recalled McMahon, "it made me realize how much power unions

\footnotetext{
${ }^{228}$ Prior to working at Powell's Books, Nancy Sturken was member of the American Federation of Teachers, even serving as president of her local for a year, while working as a pre-school teacher.

${ }^{229}$ Ryan Takas, interviewed by Edward Beechert, Local 5 Oral History Project, ILWU Library, April 26, $2001,2$.

${ }^{230}$ Winzig, ILWU Oral History Collection, Tape 1, 6.
} 
could have, if done right. That sort of inspired me to go to Union Summer."231 While Powell's employee Marc Perry had multiple years of experience as a union member in the steel industry and construction trades before starting at Powell's, he was initially hesitant to join the organizing campaign because of hearing how the 1991 union drive failed. ${ }^{232}$ Furthermore, Kruse recalled, some employees' negative union experiences became obstacles to overcome in conversations about the Powell's campaign. Although unfamiliar with unions, Meredith Schafer, who started working at Powell's in November 1998, supported Local 5 because of previously ingrained progressive principles. Like Winzig, Schafer participated in political activity while in college, but not directly in labor campaigns. "It was less out of a sense of personal experience, or injustice that I had witnessed at Powell's," explained Schafer regarding her decision to vote for the union, "it was just out of principle." 233

Familial relationship with positive union connotations informed several employees' decision on whether or not to support unionization. Marty Kruse's father was an active unionist in the merchant marines and used book buyer Ian McCullough became an early member of the organizing committee and drew motivation from positive experiences with unions while growing up in Detroit as the son of steelworker and union activist. $^{234}$ Carole Reichstein's grandfather was a proud union carpenter, but this positive

\footnotetext{
${ }^{231}$ McMahon, Local 5 Oral History Project, 11.

${ }^{232}$ Marc Perry, produced by Dave King, ILWU Local 5, ILWU Local 5: Victory at Powells 2000, video, 41:48, October 24, 2012, https://youtu.be/VaeNCAX2z2U; Marc Perry later served as a Communication Steward and on the bargaining team for the union following the union election. Perry also served as Local 5 's videographer for its strikes, rallies, and other store actions.

${ }^{233}$ Meredith Schafer, interviewed by Edward Beechert Local 5 Oral History Project, ILWU Library, San Francisco Calif., August 21, 2001, 2.

${ }^{234}$ Kruse, Local 5 Oral History Project, 9. Gail Kinsey Hill, "Powell’s Vote Will Plot Future," Oregonian April 18, 1999. B01; McMahon, Local 5 Oral History Project, 3.
} 
union experience among family did not immediately convince her to vote for the Powell's union and conversely contributed to the belief that unions were only for certain occupations. She recalled her grandfather pointedly asking her after the election, “Are you for the union or against the union?" Carole, who previously worked at Barnes \& Noble before starting at Powell's in 1996, recalled thinking that "unions were for people who worked in factories, coal mines, and steel workers. We're booksellers, what do we need a union for?"235 Although Jeff Hensley had no personal union experience and bookseller Mary Zartman had only a short, unremarkable stint at a unionized job, both cited their parents' involvement in labor activities as an influence on their support for the Powell's campaign. ${ }^{236}$ "I haven't had a lot of union exposure," stated Zartman, who was first hired at the company as a parking garage attendant in 1996, "but I always understood it to be people getting together to represent themselves." 237

The Powell's Books union leaders' devotion to the cause seemed to inspire coworkers and establish confidence in the campaign. McMahon and Winzig expressed how their commitment to the union drive and the improvement of working conditions at Powell's necessitated sacrifices to their personal lives. "I put my life on hold for this," remembered Winzig, "[a] lot of people did because we care about the company."238 Lengthy planning meetings and organizing conversations dominated the after-work hours of union activists. Scheduled at prime social hours, on Friday's at 8:00 p.m., the organizing committee's weekly meeting reflected both its members' immersion into

\footnotetext{
${ }^{235}$ Reichstein, Local 5 Oral History Project, 7, 2.

${ }^{236}$ Hensley, Local 5 Oral History Project, 7.

${ }^{237}$ Zartman, Local 5 Oral History Project, 3.

${ }^{238}$ Winzig, Local 5 Oral History Project, 12.
} 
organizing and their ability to fuse their social and union lives. Cal Hudson, who worked in the physical plant department, recalled first being approached about organizing by Winzig. Hudson recalled being "very impressed" with those who attended his first organizing meeting. ${ }^{239}$ “They were generally considered good workers and level-headed people," Hudson noted, “they weren't the whiners that I kind of expected to see when I went to my first meeting."240

The formation of a strong relationship between Powell's Books employees and community activists, who provided strategic pressure on the bookstore's management and moral support for workers throughout the campaign, began to take form in the immediate days and weeks following the September Surprise. Early in the campaign, booksellers Marty Kruse and Carol Edwards took the union's message on the road to other Portland union halls, building support for Local 5's cause among the local labor movement. ${ }^{241}$ The longshore workers of Portland's ILWU Local 8 provided consistent solidarity through various means, including financial support, access to the local's large hall, and participation at public actions. ${ }^{242}$ The AFL-CIO quickly took a supportive position of the Powell's campaign with Jean Eilers, who became the federation's Western Regional State Director in 1998, assisting with a one day organizing training in November. ${ }^{243}$ Nationally, president John Sweeney speculated in a letter to Michael Powell sent during the recognition campaign that a unionized workforce at Powell's

\footnotetext{
${ }^{239}$ Cal Hudson, interviewed by Edward Beechert, Local 5 Oral History Project, ILWU Library, May 20, 2001, 1-2.

${ }^{240}$ Hudson, Local 5 Oral History Project, 6.

${ }^{241}$ Kruse, Local 5 Oral History Project. 6-8.

242 Olney, Local 5 Oral History Project, June 3, 2002, 8-9.

${ }^{243}$ McIntosh, "Powell's Books Trying to Stifle Organizing Drive by ILWU," https://nwlaborpress.org/1998/12-18-98Powells.html.
} 
would translate into a windfall of sales for his store from the federation's 30 million union members. ${ }^{244}$ "Powell's was kind of a sexy place to organize," explained Winzig, regarding why the booksellers received such an outpouring of community support. ${ }^{245}$

Organizing in what became known as Portland's living room meant that the union drive "was a community campaign from the beginning," stated Michael Cannarella, "because everybody has an opinion [...] on Powell's."246 Indeed, the campaign caught the attention of novelist and Portland resident Ursula K. Le Guin as well as Oregon Fourth District Congressman Peter DeFazio (D), who both contacted Michael Powell voicing their support for the union. ${ }^{247}$ The organizing committee's early demand for a "living wage" illustrated the success of community organizations, such as Jobs with Justice, to challenge the low wage economy and bring the issue of local economic inequality to the forefront of worker's attention. Jobs with Justice, comprising forty community partners by the start of the Powell's campaign, helped coordinate a letter writing campaign to Michael Powell with a hundred organizations and individuals during the months leading up to the union vote. Ultimately, Jobs with Justice proved crucial in harnessing and directing the community support, acting as the new union's most important local partner and conduit to sympathetic organizations and individuals.

The Workers' Organizing Center (WOC) opened its doors to the Powell's campaign soon after the union's formation, providing worker-organizers an outpost to

\footnotetext{
244 Tom Bates, “What Are We to Read into Powell's Union?” Oregonian, May 2, 1999, G01.; Rein, “Organizing by the Book," http://archive.ilwu.org/wp-content/uploads/2015/04/19990301.pdf; William Kramer, "Powell's Workers, Backed by AFL-CIO President John Sweeney, Say Unions Mean Business," Press Release, ILWU Library, ILWU Local 5 Document Archive, April 21, 1999.

${ }^{245}$ Winzig, ILWU Oral History Collection, Tape 1, 32-33.

${ }^{246}$ Cannarella, Local 5 Oral History Project, 8.

247 Tom Bates, “What Are We to Read into Powell's Union?” Oregonian, May 2, 1999, G01.
} 
operate from during the organizing and recognition phases. While initial gatherings in bars and coworker living rooms strengthened the bonds between those who formed the early organizing committee, a central and neutral meeting space proved necessary to welcome workers from other store locations, many of whom were not socially connected to the organizers. "They were so helpful to us," recalled McMahon appreciatively of WOC, who assigned a staff member to the campaign and provided the new bookstore union with the "space we needed when we needed, helpful advice, or just pats on the back when you got beat down all day at work." 248 WOC's location on East Burnside Street between multiple Powell's locations (one mile east of the downtown store and Hoyt warehouse and two-and-half miles from the Hawthorne locations) provided employees a convenient meeting and workspace.

\section{A Contest of Culture}

The union organizing committee emphasized that its campaign sought to preserve the unique and independent culture of Powell's Books, while simultaneously altering the workplace culture. Fear of the "Killer Bees" (Borders and Barnes \& Noble) permeated the minds of both management and employees, who set upon divergent courses to preserve the future of Portland's premier independent bookstore. A slogan that generated the significant traction among workers was emblazoned on stickers and recited often in organizing conversations: "No Decisions About Us Without Us." The slogan and its popularity reveal the emergence of a collective identity among Powell's employees that stood at odds with company's increasingly corporate structure, leadership, and vision for

${ }^{248}$ McMahon, Local 5 Oral History Project, 5; McIntosh, "Powell's Books trying to stifle organizing drive by ILWU," https://nwlaborpress.org/1998/12-18-98Powells.html. 
the future. "We didn't sit back and watch the company become a locally owned version of Barnes \& Noble," explained the union's February 1999 newsletter, “Instead we decided to do something." ${ }^{249}$ Rather than insisting on the inclusion of workers in the decision-making process as previous bookstore union campaigns had argued, the organizing committee presumptuously took issue with how booksellers' "voices were being stripped and removed from the decision process" that already existed at Powell's. ${ }^{250}$ "Something at Powell's was lost," stated an editorial in the February 1999 issue of the union's newsletter Fearless. The article explained that the union drive began because management's decisions impacted workers "out of the blue and without apparent recourse," a reference to the staff restructuring and the September surprise. The solution and reasoning offered by Paul Couey illustrated the radical ambitions of some union activists: "a democratic work place is a basic human right." 251

Union activists explicitly connected the culture of Powell's Books to the working conditions of booksellers. Despite a perception among activists that management increasingly treated the workforce like a commodity, the employees nevertheless continued to take great pride in their skills and their role in the shepherding books to customers and customers to books. "We cared about our jobs and we liked what we did," stated Winzig, adding "we wanted to save what we thought was the culture of Powell's or what we thought made Powell's a great place to work." ${ }^{252}$ The emphasis on working conditions extended beyond wages and benefits, encompassing both a voice in the labor

\footnotetext{
${ }^{249}$ ILWU Local 5, "To the Unconvinced...," 1.

${ }^{250}$ ILWU Local 5, "To the Unconvinced...," 1.

${ }^{251}$ ILWU Local 5, "Please Join Us," leaflet, ILWU Library, ILWU Local 5 Document Archive, circa 19981999.

${ }^{252}$ Winzig, ILWU Oral History Collection, Tape 1, 17.
} 
process and a recognition of the position of the bookseller in the retail interaction. McMahon elaborated on this relationship, explaining that "the union was an attempt to retrieve that feeling that the employee was as important as the books that the employee sells to making this place successful.", 253 "To preserve something," stated McMahon, "not to alter it so it's unrecognizable." Nonetheless, challenging Michael Powell demanded a loyalty that extended beyond the patriarch of a landmark store and to a much larger ideal. Bookseller Meredith Schafer, who started at Powell's in November 1998 and became a union supporter in the spring, described why her coworkers started to organize: "They weren't loyal to him, they were loyal to the books. They were loyal to the idea."254 Management eventually learned about the union campaign in November and implemented a union avoidance strategy that paired well with the liberal identity of Michael Powell and the culture of his store. In addition to a contest of power, the union campaign created a discourse over the culture and values of the workplace. In a March 16 statement to employees that reflected the tenets of neoliberalism, Michael Powell wrote of his store, "This is a special culture built on individuality, on diversity, on respect for the individual. I do not want to see us trade that in for the kind of adversarial relationship that the union is already bringing us." ${ }^{255}$ Reactively, the Powell's upper management responded to the ILWU campaign by spearheading a counter-organizing effort, which similarly sought to educate workers. Michael Powell hired on the services of Amburgey and Rubin, a Portland labor law firm experienced with negotiating with unions, to achieve this goal. On November 12, managers sent a notice informing employees of their

\footnotetext{
${ }^{253}$ McMahon, Local 5 Oral History Project, 12-13.

${ }^{254}$ Schafer, Local 5 Oral History Project, 19.

${ }^{255}$ Kinsey Hill, "Powell’s Vote Will Plot Future,” B1.
} 
legal right to oppose the unionization if they did not want to be represented by a union or if they believed a "[union] isn't the right thing for Powell's." ${ }^{256}$ Additionally notices followed, both inside the store and directly to employees' homes.

Management's educational strategy backfired when the company confused the ILWU with its rival East Coast counterpart, the International Longshore Association (ILA). Earlier in November, a letter sent to employees by Michael Powell, Miriam Sontz, and Corporate Manager Ann Smith stated, "We do not believe that a third party in the form of the Longshoreman's union (or any other union) is needed here." ${ }^{257}$ When union activists promoted the fact that the longshore union president voluntarily took a pay cut, Powell's management cried foul and released a five-page letter cautioning support for the union campaign because the $I L A$ 's president received a $\$ 302,324$ annual salary. ${ }^{258}$ Powell's employees leapt at the opportunity to showcase the error made by the company and its legal counsel, printing flyers highlighting the differences between the two longshore unions and the fact that a Powell's marketing manager could receive a larger annual salary $(\$ 83,200)$ than ILWU President Brian McWilliams $(\$ 72,800) .{ }^{259}$ Peter Olney years later recalled how this series of events captured the dynamic between the union and management: "You have a very intelligent, erudite, articulate, well-read workforce who were very much tit-for-tat in terms of matching wits with the employer

\footnotetext{
${ }^{256}$ Russ, "No Decisions About Us Without Us: A History of a Bookstore Union,” http://ilwulocal5.com/?page $\mathrm{id}=46$.

${ }^{257}$ McIntosh, "Powell's Books Trying to Stifle Organizing Drive by ILWU," https://nwlaborpress.org/1998/12-18-98Powells.html.

${ }^{258}$ McIntosh, "Powell's Books Trying to Stifle Organizing Drive by ILWU," https://nwlaborpress.org/1998/12-18-98Powells.html.

${ }^{259}$ McIntosh, "Powell's Books Trying to Stifle Organizing Drive by ILWU," https://nwlaborpress.org/1998/12-18-98Powells.html.
} 
around facts, figures, and intelligence." ${ }^{260}$ For similar reasons as to why union activists did not support house visits, organizers asserted that their coworkers found the company's several letters sent to their homes as out of step with the culture of the bookstore. $^{261}$

Powell's management conducted a tour of captive-audience meetings, generally considered by labor relations experts as a company's best antidote to union drives, at several store locations between November 1998 and February 1999. ${ }^{262}$ Powell, Sontz, and Smith used these meetings to create a controlled environment to ingratiate themselves to front-line workers and to address employees about potential repercussions of unionization, subtly personalizing the conflict as an assault upon Powell. The organizing committee struggled with how to respond during these meetings, knowing that speaking up meant outing themselves as union activists and remaining silent meant appearing weak. Nevertheless, organizing committee members took a variety of actions, including taking strategic seats in the room and taking copious notes for written rebuttals. An argument between McMahon and Powell ensued at the first Burnside meeting, convincing Marty Kruse that direct dialogue with management without union recognition was naive and generated a negative effect. ${ }^{263}$ Nonetheless, the meetings also created an opportunity for the union to display leadership, as was the case when Winzig stood

\footnotetext{
${ }^{260}$ Olney, Local 5 Oral History Project, June 3, 2002, 8.

${ }^{261}$ McIntosh, "Powell's Books Trying to Stifle Organizing Drive by ILWU," https://nwlaborpress.org/1998/12-18-98Powells.html. Northwest Labor Press reported six letters mailed to workers between November 2 and December 18.

${ }^{262}$ McIntosh, "Powell's Books Trying to Stifle Organizing Drive by ILWU," https://nwlaborpress.org/1998/12-18-98Powells.html. The Northwest Labor Press reported, "Between Nov. 19 and Dec. 3, at least eight employee meetings were held, at which Powell spoke about the union and responded to questions..."

${ }^{263}$ Kruse, Local 5 Oral History Project, 5.
} 
before management and coworkers at a meeting to announce publicly her support for the union. ${ }^{264}$ While actions such as Winzig's helped to neutralize the negative impact of the captive audience meetings, Carole Reichstein considered Michael Powell's behavior demeaning and observed other workers becoming agitated by his patronizing attitude. ${ }^{265}$ By the time Powell's learned of the union campaign, the organizing committee had already created a communication network that relayed information throughout the company and drew upon the skills of the workforce. "The best organizing tactic," stated Cal Hudson and echoed by other organizers, "is just the face-to-face talk with coworkers. ${ }^{266}$ From the outset, organizers talked to coworkers about what they wanted to see in a contract and explained to workers how the company would respond, inoculating them to the letters sent to their homes, the captive audience meetings at work, and the depiction of the union as an outside third party ${ }^{267}$ Hudson, who started with the company in 1995, also highlighted the "caliber" of the union activists and frequency of their contacts with fellow coworkers. ${ }^{268}$ In order to trigger and enter a union election with confidence, the organizing committee sought to collect authorization cards from 60 percent of the Powell's workforce. Organizers gathered these signed cards through oneon-one get-togethers and by holding informational sessions immediately prior to its Friday organizing committee meetings for booksellers interested in signing authorization cards. Simultaneously, organizers recruited union supporters to serve as communication stewards, who relayed information on to coworkers within their informal work groups.

\footnotetext{
${ }^{264}$ Winzig, ILWU Oral History Collection, Tape 1, 28-30.

${ }^{265}$ Reichstein, Local 5 Oral History Project, 6.

${ }^{266}$ Hudson, Local 5 Oral History Project, 6.

${ }^{267}$ Winzig, Local 5 Oral History Project, 7.

${ }^{268}$ Hudson, Local 5 Oral History Project, 6.
} 
"We became sort of the muscle of the union that made everyone else move in concert," stated Meredith Schafer. ${ }^{269}$

The Powell's Books union activists wrote prolifically about the campaign, using the written word as one of their primary organizing tools. After the first meeting at Ringler's, Marty Kruse began writing and circulating a pamphlet he called Fearless, which eventually led to the creation of the local's newsletter Bridges. Kruse's description of Fearless as a zine highlighted both the literary character of the workforce and the publication's purpose as a propaganda and organizing tool during the recognition campaign. The zine, passed clandestinely among workers, made the case for unionization and informed workers about upcoming opportunities to meet and socialize as a union. Kruse's creation quickly transformed into a collaborative project of the union's communications committee, giving space to other workers, including John McMahon and Call Hudson, to contribute their writing skills. Winzig described how these writing opportunities allowed the union to regularly counterpoint information circulated by management, while simultaneously providing an avenue for Hudson and others to plug into the campaign. ${ }^{270}$ After learning about the union drive from Winzig and attending an early organizing committee meeting, Hudson got involved with the communications committee writing the "Question and Answer" section of the zine. ${ }^{271}$

Employees opposed to unionization succeeded in helping shape the discourse on the controversial topic among the workforce, but failed to coalesce into a substantive

\footnotetext{
${ }^{269}$ Schafer, Local 5 Oral History Project, 3; Mary Winzig, "Mary Winzig and the Powell's Organizing Drive, 1998-2000," ILWU, published April 21, 2008, last modified August 9, 2011, http://www.ilwu.org/mary-winzig-and-the-powells-books-organizing-drive-1998-2000/.

${ }^{270}$ Winzig, ILWU Oral History Collection, Tape 3-4, 13.

${ }^{271}$ Hudson, Local 5 Oral History Project, 2-3.
} 
anti-union movement. Most of the opposition to the union organizing campaign came from workers who did not identify with the union or who feared change. The divide among employees on the issue of unionization became visibly apparent when both sides began wearing buttons. Kruse and the organizing committee spearheaded an effort to distribute ILWU Local 5 buttons to supporters to wear on shift and on coordinated "button days." 272 Union activists hoped to show their numbers and create opportunities for coworkers to support the union. In response to the appearance of pro-union buttons, the opposition hastily made anti-union pins that also began appearing on the lapels and lanyards of Powell's employees. Using one of the union's own buttons, Carole Reichstein designed and produced the opposition pins. Reichstein distributed the anti-Local 5 pins amongst her Tech Store coworkers. ${ }^{273}$ In recalling her early opposition to unionization, she made the distinction that the buttons “weren't anti- union, but they were anti-Local 5."274

Even organizing committee members feared that public actions, such as wearing pins, could lead to management retaliation. "I had my union button in my pocket for the longest time," admitted Mary Winzig, who grew more confident after seeing other unionactivists display their pins. ${ }^{275}$ When British musician-activist Billy Bragg visited Portland

\footnotetext{
${ }^{272}$ Kruse, Local 5 Oral History Project, 5.; McIntosh, "Powell's Books trying to stifle organizing drive by ILWU," https://nwlaborpress.org/1998/12-18-98Powells.html; Rein, “Organizing by the Book," http://archive.ilwu.org/wp-content/uploads/2015/04/19990301.pdf.

${ }^{273}$ Carole Reichstein, "Confessions of a (former) Local 5 Buster: Part Two, Union 101 Class," Bridges, ILWU Library, ILWU Local 5 Document Archive, March, 2002, 2.

${ }^{274}$ Reichstein, Local 5 Oral History Project, 5.

${ }^{275}$ Brandon Cotter, "Forget George Dubya, Meet Our Local's First President," Bridges, ILWU Library, ILWU Local 5 Document Archive, March/April 2001, 1; ILWU Local 5, "Organizing Drive Timeline," Welcome to ILWU Local 5, http://www.ilwulocal5.com/Timeline.html\#91498, Internet Archive, accessed December 26, 2016, https://web.archive.org/web/20010815134405/http://www.ilwulocal5.com/Timeline.html\#91498.
} 
while on tour playing previously unpublished Woody Guthrie songs, Bragg made a point of visiting Powell's workers at the downtown store. ${ }^{276}$ Winzig gave him a union button and introduced him to general manager Miriam Sontz. In response to her fear of retaliation for that encounter and other union activity, Winzig remembered Bragg thoughtfully asking her, "What would Woody do?" and inspirationally telling her that she was "doing Woody's work." 277 That night, Bragg dedicated his union anthem "There Is Power in a Union" to the Powell's booksellers and record store workers of Music Millennium, both of whom were organizing unions.

In dialogue with the union activists, opponents to the ILWU union drive also made their case publicly known using the written word. Through entries in the staff's day book, open letters, and pamphlets, opponents often stated their general support for unions but not specifically at Powell's Books or with the ILWU. The Burnside store's employee day book located in the break room became an open venue for discussion about the union campaign. Cal Hudson remembered that some the union's first propaganda came out of the anonymous discussions being held through entries in the day book among union activists, opponents, and undecided workers. In one such propaganda flier, titled "Making a great place to work even better," union activists listed thirteen qualities that characterize Powell's Books "Now" and "With a Union." The flier argued that a union "guaranteed" the continuation of many of the qualities Powell's workers enjoyed. ${ }^{278}$ Management,

\footnotetext{
${ }^{276}$ Rein, “Organizing by the Book,” http://archive.ilwu.org/wp-content/uploads/2015/04/19990301.pdf: The list of musicians who publicly supported the Powell's Books union campaign while on tour in Portland included Utah Phillips and the bands Fugazi and the Austin Lounge Lizards.

${ }^{277}$ Winzig, ILWU Oral History Collection, Tape 1, 36.

${ }^{278}$ ILWU Local 5, "Making a great place to work even better," leaflet, ILWU Library, ILWU Local 5 Document Archive, 1999.
} 
aware of the discourse, took keen notice; Hudson recalled witnessing a Human Resources manager coming in early to photocopy the discussions in the day book. ${ }^{279}$

Not all booksellers believed that a union guaranteed the maintenance of the most valued qualities of working at one of the nation's finest bookstores. Employees Jim Cowing and Doug Chase both penned public letters to their coworkers opposing the union drive. In response to union organizers' calls for a living wage for Powell's employees, Cowing wrote what he described was a "four-page diatribe" mathematically detailing how the company could not afford even a dollar an hour raise for workers. ${ }^{280}$ Doug Chase, in his own four-page letter titled "Why I Don't Think This Is a Good Idea Right Now," raised eight concerns about a union's ability to improve working conditions beyond those currently existing at Powell's. Working single and co-parents, such as Chase, worried that a union could mean an end to the child care benefit provided by Powell's. Chase concluded that the benefit would likely be "dropped" to provide wage increases for the majority of employees since working parents represented a fraction of the workforce, a turn of events, requiring him to quit and find work elsewhere. Although he began his letter agreeing with an article in Fearless that asserted that unions remain a relevant and positive force for workers, ultimately Chase's memo articulated fears he and other employees had about how ILWU representation would not improve working conditions but actually "bring a net loss" to employees. "[This] doesn't mean we are against unions," clarified Chase speaking for himself and other opponents of the drive,

\footnotetext{
${ }^{279}$ Hudson, Local 5 Oral History Project, 4.

${ }^{280}$ Cowing, Local 5 Oral History Project, 6.
} 
"we just feel that this particular drive at this particular time is not addressing all salient points."281

The organizing committee responded publicly to Chase's concerns with a set of open letters to Powell's employees. ILWU organizer Michael Cannarella, who previously served on a child care advisory board to the governor, described Chase's allegations as "upsetting” in a letter titled "Childcare Credit giveaway or scare tactic?" Cannarella fired back at the assumption that "a co-worker would sacrifice these support systems for another ten cents an hour," adding that "without a doubt fear is the best anti-union technique." 282 A second letter from the organizing committee reiterated that organizing a new local with the ILWU provided Powell's employees with the independence to bargain for a contract "tailored to our individual and cultural needs." ${ }^{283}$ Ultimately, opposition to the ILWU failed to coalesce into an anti-union movement and depended primarily on select independent actions.

Six months after the union's first meeting, the organizing committee had collected the prerequisite number of signed union authorization cards from Powell's Books employees necessary to trigger a National Labor Relations Board (NLRB) election. On March 12, Powell's employees rallied and held a press conference on the front steps of the Burnside store to announce their intention to file for an election with the support of 64 percent of the workforce. A crowd of one hundred community supporters (largely

\footnotetext{
${ }^{281}$ Doug Chase, “Why I don’t Think This Is a Good Idea Right Now," leaflet, ILWU Library, ILWU Local 5 Document Archive, 1999.

${ }^{282}$ Michael Cannarella, “Childcare Credit giveaway or scare tactic?” leaflet, ILWU Library, ILWU Local 5 Document Archive, 1999.

${ }^{283}$ ILWU Local 5, “Will we ever have to pay for other locals' mistakes?" ILWU Library, ILWU Local 5 Document Archive, 1999.
} 
connected to Jobs with Justice) looked on and cheered the Powell's employees, who together called for a "fast and fair union election." ${ }^{284}$ The assembly then took this message, in the form of a four-foot-long petition, directly to Michael Powell, who agreed to the speedy election but still hoped staff would align their priorities to those of his company. "They've got to ask themselves," Powell told the Oregonian about his employees, "whether this is really in the best interests of the company." 285 A day earlier, the organizing committee and Jobs with Justice coordinated a "Union Shop Day" (the equivalent opposite of a boycott) to move the message to store employees that the local labor community supported them and the unionization effort. With the NLRB mediating, the ILWU and Powell's quickly agreed on the terms of the election, including the classified workers considered part of the bargaining unit.

Workers, management, and the public anxiously awaited the April 22 election results. Both management and the union disputed their counterpart's claim of majority support, and many observers anticipated a close vote. By chance, Winzig was called for jury duty the week of the election and found herself detached from the workplace at a critical moment when every conversation with coworkers about the importance of voting and voting union seemed like the deciding ballot. Yet, Winzig recounted needing to share with the other jurors, who were following the reports about the campaign, the perspective of her fellow booksellers, which she felt the local media misrepresented. "Why would employees," questioned Oregonian reporter Gail Kinsey Hill, “want to put Powell’s

\footnotetext{
${ }^{284}$ Rein, "Organizing by the Book," http://archive.ilwu.org/wp-content/uploads/2015/04/19990301.pdf; ILWU Local 5, “A Message to Michael Powell," petition, ILWU Library, ILWU Local 5 Document Archive, March 12, 1999.

${ }^{285}$ Gail Kinsey Hill, "Powell's Employees Say Changes in Pay, Operations Force Union Push,” Oregonian March 12, 1999, B1.
} 
literary culture at risk by forming a union?" Winzig recalled fondly the support she received from her fellow jurors. Nevertheless, she remembered being convinced the union would lose on voting day. ${ }^{286}$ Alternatively, John McMahon recounted being confident that the union would win solidly. ${ }^{287}$

Seemingly, the future of Powell's Books and its idealized cultural position in Portland teetered on the results of this union election. If a simple majority of eligible employees vote "YES" on unionization during a NLRB's election process, the employer is legally mandated to recognize the union and provide the selected labor organization exclusive bargaining rights for a year. A tie or less awards no rights to the union and creates a one-year waiting period before conducting another election, thus creating a zero-sum contest for labor organizations. While for the organizing committee a victory represented the opportunity to bargain over wages and working condition with management for the first time, a defeat meant an affirmation of management's unilateral ability to determine the working conditions and future of the iconic Northwest bookstore. Additionally, the more ambitious unionists and labor activists believed that a success in the Powell's election could lead to a broader shift of power in the retail economy, inspiring other low-wage retail workers to organize, swelling the ranks of Local 5 and the labor movement.

Altogether, 321 employees from all seven retail locations and supporting facilities (approximately 90 percent of all eligible workers) turned out to vote. As the NLRB agent counted the ballots in front of observers from both the union and Powell's management,

${ }^{286}$ Winzig, Local 5 Oral History Project, Tape 3-4, 6.

${ }^{287}$ McMahon, Local 5 Oral History Project, 5. 
Michael Powell awaited the results of the election by pacing the aisles of the Tech Store where nearly all employees opposed the union. ${ }^{288}$ The final tally counted 161 votes for the union, 155 against, and 5 challenged ballots not counted. ${ }^{289}$ The Powell's booksellers, the ILWU, and the Portland labor community had won (albeit narrowly) the seven-month organizing and union recognition campaign within an economic climate where labor lost more than half of all elections in $1999 .{ }^{290}$ Local 5 made history as the largest bookselling workforce to vote in favor of unionization, yet the election proved far from a mandate.

For Local 5 to transition its election success into a voice within the company's affairs and improvements in working conditions, the union needed to successfully bargain a contract with Powell's Books or face potential decertification. Whereas Local 5 had won the debate on the question of unionization through one-on-one conversations and the printed word, a defiant management soon tested the solidarity of the union and its ability to act. The next stage of contract bargaining would last sixteen months and prove rancorous beyond all expectations, including strikes, street theater, and police lines that escalated the tension within both the bookstore and the Portland community.

\footnotetext{
288 Reichstein, Local 5 Oral History Project, 4.

${ }^{289}$ Gail Kinsey Hill, "Powell's Staff Approves Union,” Oregonian, April 23, 1999, C01.

${ }^{290}$ National Labor Relations Board, Sixty-Fourth Annual Report of the National Labor Relations Board for the Fiscal Year Ended September 30, 1999 (Washington, D.C.: U.S. Government Printing Office, 2001), 152.
} 


\section{Chapter 4}

\section{"The Street Drives the Table": Bargaining a First Contract}

As a result of the union's election success at Powell's Books, federal labor law required the store's management to bargain in good faith with Local 5 booksellers over a first contract. Yet, negotiations proved anything but cordial, unfolding into a protracted power struggle between Michael Powell and booksellers that lasted eleven months. Coincidentally, the first bargaining session between labor and management occurred on the year anniversary of the September Surprise email that ignited the union organizing campaign. The subsequent series of escalating actions and reactions by both parties created a tension in the workplace that spilled over into the streets of downtown. The conflict compelled the city and the media to choose sides in a manner reminiscent of Portland's 1959 newspaper strike or the 1934 longshore strike. In particular, Local 5's struggle for a first contract provided Portland's radical and progressive communities a campaign around which to organize and participate alongside an already growing antiglobalization movement.

Following the election, ILWU Local 5 transitioned from primarily organizing booksellers for union recognition to conducting the myriad of tasks necessary to negotiate and win a first contract. Simultaneously, the union needed to organize "No" voters behind the union's future, establish mutual aid relationships with local social justice movements, and demonstrate that booksellers could take collective action. These and many other related concerns converged into the most imperative demand of all: Local 5 needed to exert sufficient economic and social pressure upon Michael Powell to compel 
him to agree to a first contract that forfeited power and a greater share of the company's profits.

Although Local 5 could claim victory in the union election, the narrow margin left space for varying interpretations of the election's outcome. Booksellers John McMahon and Mary Winzig both attributed the close election results to employees' fear of the unknown, specifically a feeling of uncertainty about how their day-to-day work lives would change with a union. ${ }^{1}$ Powell and his team of management and lawyers proved unwilling to accept the results of the election. The store owner himself refused to meet with the union and continued to make statements to journalists that illustrated that he did not think unionism was something his employees needed. 'You say the word 'union,' and everyone's supposed to feel all squishy. I don't get it," Powell stated to a reporter in the months between the election and the start of bargaining. "I understand if you're organizing farm workers, or people in Bangladesh," conceded Powell, "But this is not that kind of situation."2 ILWU Regional Organizer Michael Cannarella explained how management misunderstood the vote tally, wrongly interpreting the "No" vote as a vote for management:

I think the [recognition vote] was very close and I think that made the management team feel as though there were a lot of people on their side. I think if you talk to some of the tech store [employees] and some of the people that came our way after the vote, what you'll find out is that they weren't necessarily on management's side. They saw there were a lot of problems. [...] Over the course of the next year and a half, as we're bargaining and we're bringing those issues to the table, one after another, we slowly brought people to our side because they

\footnotetext{
${ }^{1}$ John McMahon, interviewed by Edward Beechert, Local 5 Oral History Project, Anne Rand Library, International Longshore and Warehouse Union, San Francisco Calif. (hereinafter ILWU Library), November 19, 2001, 3-5; Mary Winzig, interviewed by Harvey Schwartz, ILWU Oral History Collection, ILWU Library, June 11, 2001, Tape 3-4, 1-2.

${ }^{2}$ Liza Featherstone, “'It’s Business, Man!': Unions and 'Socially Responsible' Corporations,” Dissent, Fall 1999, https://www.dissentmagazine.org/article/its-business-man-unions-and-socially-responsiblecorporations.
} 
realized that we're the only ones trying to deal with the problem. Management was just saying, 'Hey, you don't have any problems here, everything is OK.' So, if there was a strategic mistake [management] made, it was thinking that the NO votes thought everything was $\mathrm{OK}$. The NO votes didn't think everything was OK, but they hadn't really decided the union was the way of addressing those problems. ${ }^{3}$

Thus, the outcome of the contract negotiations depended upon which of the two opposing sides could polarize the workplace towards its position.

\section{Open Bargaining and the Polarization of the Workplace}

In the five months between the election and the start of bargaining, both sides prepared their teams of negotiators. Michael Powell assigned the duty to his management team and lawyers, a common practice in corporate circles but a decision that booksellers nevertheless held against him. Powell's legal counsel prepared a post-election strategy seemingly aimed at stalling contract negotiations for as long as possible. Local 5's organizing committee and communication stewards, established during the union's organizing phase, carried on the vital role of coordinating the activity of the union and outreaching to booksellers. On the opposite side, union activist continued outreaching to employees following the election by circulating a bargaining survey, conducting organizing conversations with booksellers, and meeting with new hires. Local 5's first bargaining surveys after the election provided the contract team a snapshot of the workforce and their priorities for the union's first contract proposals. Demographically, the survey of 181 respondents confirmed many of the public's assumptions of Powell's employees: half were between the ages of 25 - 35 years old and 90 percent reported at least some college education.

\footnotetext{
${ }^{3}$ Michael Cannarella, interviewed by Edward Beechert, Local 5 Oral History Project, ILWU Library September 4, 2002, 14-16.
} 
As for the booksellers' bargaining priorities, workers repeatedly identified wages as a top priority throughout the survey. Overwhelmingly, workers thought the minimum wage for new employees should increase from $\$ 6.50$ to $\$ 7.50$ per hour. More than half of respondents stated they needed a raise or a fair wage in response to the question, "What can Powell's do to make you a better employee?" As for benefits, employees did not want to trade away any current benefits and prioritized improvements to the company's vision health program, educational stipend, and $401 \mathrm{~K}$ program. Booksellers were particularly discontented with the company's profit sharing program with only 9 percent of respondents wanting to keep the program's current set up, preferring to either eliminate the threshold for sharing or trade away the program for a permanent wage increase. $^{4}$

Whereas the bargaining survey helped determine the priorities for the union's first contract, the outreach to new workers and those who voted against the union proved critical in building unity to achieve an agreement with management. ILWU organizer Michael Cannarella recalled reaching out to new employees was a significant task for organizers since ten to twenty new employees started with the company each month. ${ }^{5}$ Communication stewards identified and recruited new leaders, including Meredith Schafer by keeping the conversation regarding the union at the forefront for both seasoned and green booksellers. ${ }^{6}$ Subsequently, Schafer became a communication steward herself in the wake of the election. By January 2000, Local 5 had thirty-nine

\footnotetext{
${ }^{4}$ ILWU Local 5, “Survey Says...,” ILWU Library, ILWU Local 5 Document Archive, 1999.

${ }^{5}$ Cannarella, Local 5 Oral History Project, 11-14

${ }^{6}$ Meredith Schafer, interviewed by Edward Beechert Local 5 Oral History Project, ILWU Library, August 21, 2001, 1-3.
} 
stewards spread out across nine worksites and twenty teams. ${ }^{7}$ Furthermore, for Local 5 to successfully secure a contract and its bargaining goals, organizers understood the urgent need to build support amongst the other half of the workforce who voted against unionization.

Anti-union strongholds, such as the Tech Store, required immediate attention after the election. Tech store employees Carole Reichstein and Jim Cowing indicated that their coworkers' opposition to the union derived from a more congenial management approach taken by supervisors at their store compared to at the City of Books. ${ }^{8}$ Moreover, Cowing described a prevailing culture within their work group that was "conditioned" to hold suspect any interference from the outside. ${ }^{9}$ Soon after the election, Cannarella met with Tech Store booksellers to discuss what the workers could expect now with a union in the workplace. ${ }^{10}$ Such efforts proved successful, as demonstrated by the leadership roles both Reichstein and Cowing took within Local 5 after voting "No" during the election. Reichstein served as a communication steward for her worksite and Cowing joined the bargaining team. Both had the support of unionists at the Burnside store and many of the anti-unionists at the Tech Store that saw them as their advocate within a union dominated by the City of Books workers. ${ }^{11}$ Cowing proved a consistent and reliable Local 5 representative throughout the many incarnations of the union's bargaining team, holding

\footnotetext{
${ }^{7}$ ILWU Local 5, "Bargaining Team, Stewards Contact List” ILWU Library, ILWU Local 5 Document Archive, January $3 \& 4,2000$.

${ }^{8}$ Carole Reichstein, interviewed by Edward Beechert, Local 5 Oral History Project, ILWU Library, April 17, 2002, 3.

${ }^{9}$ Jim Cowing, interviewed by Edward Beechert, Local 5 Oral History Project, ILWU Library, August 28, 2001, 3.

${ }^{10}$ Reichstein, Local 5 Oral History Project, 3-4.

${ }^{11}$ Cowing, Local 5 Oral History Project, 5-7.
} 
the distinction along with Keith Brooks as the only two members who were a part of bargaining team for the full eleven months of negotiations. ${ }^{12}$

Union activists believed that the Powell's management team's bargaining strategy

from the outset was to stall the proceedings for as long as possible and, if necessary, bring in a federal mediator. "Our feeling," bookseller John McMahon speculated, "was that they were going to try to take it all the way to impasse." ${ }^{13}$ A declared impasse could potentially send the contract negotiations to binding arbitration. " "That would be it," concluded McMahon, "Make us put up or shut up." ${ }^{\prime 15}$ While stalling represented a tested and true union avoidance tactic for Powell's attorney Larry K. Amburgey, Schafer conjectured the strategy dually served to legitimize his role and maximize his financial gain. ${ }^{16}$ Mary Winzig, who started working for Powell's in 1995, recognized that the company hired a noticeably younger workforce after the union election, which suggested to her that the company believed these workers would have little interest in the long term goals of a union. Contrarily, Winzig described that many young new booksellers making $\$ 7.00$ per hour proved to be enthusiastic supporters of the union compared to other Powell's booksellers, who had the privilege of a "nice little niche carved out for themselves." 17

Local 5's early decision to insist on open bargaining, an arrangement in which any Powell's employee could attend and observe contract negotiations, proved a decisive

\footnotetext{
${ }^{12}$ Cowing, Local 5 Oral History Project, 12-15.

${ }^{13}$ McMahon, Local 5 Oral History Project, 5-8.

${ }^{14}$ Peter Olney, interviewed by Harvey Schwartz, Local 5 Oral History Project, ILWU Library, June 3, 2002, 22-24.

${ }^{15}$ McMahon, Local 5 Oral History Project, 5-8.

16 Schafer, Local 5 Oral History Project, 11.

${ }^{17}$ Mary Winzig, interviewed by Edward Beechert, Local 5 Oral History Project, ILWU Library, August 20, 2001, 4; Cowing, Local 5 Oral History Project, 7-10.
} 
factor in mobilizing support. The ILWU's Michael Cannarella viewed bargaining as a component of organizing and described the open sessions as an educational opportunity that facilitated the attendance of crowds of booksellers, but never Michael Powell. ${ }^{18}$ The union opted for a large bargaining team consisting of at least nine booksellers plus Cannarella and later Olney. ${ }^{19}$ Lack of previous bargaining experience did not prevent bookseller Carol Edwards from emerging as a leader on the union's team. "Everyone's in awe of Carol," expressed Winzig, "nothing rattles her." ${ }^{20}$ Amburgey and Howard Rubin, two seasoned labor law attorneys, provided Powell's the labor relations negotiating experience the store's management team lacked. "I knew his style," recalled ILWU organizer Michael Cannarella of Amburgey, since the two had negotiated against each other in the past. ${ }^{21}$ Cannarella anticipated Amburgey's confrontational approach, believing that open bargaining would allow "the rank and file to see who their employer had hired to deal with them," Amburgey "didn't let me down at all," he added. ${ }^{22}$

Contract bargaining moved the workforce toward the union more successfully than any other action taken by the union or Powell's management between 1998 and $2000 .{ }^{23}$ Unanimously, Powell's employees agreed that Amburgey's role in the negotiations reflected poorly upon Michael Powell. McMahon attributed the local's bargaining power to its open structure and expressed gratitude for Amburgey's ability to solidify union support. "We owe Larry a debt of gratitude," McMahon sardonically

\footnotetext{
${ }^{18}$ Cannarella, Local 5 Oral History Project, 8-11; Schafer, Local 5 Oral History Project, 5-8.

${ }^{19}$ Cannarella, Local 5 Oral History Project, 8-11.

${ }^{20}$ Shelly Herochik, "Powell's Contract Negotiations Following an Old Script," 55.

${ }^{21}$ Cannarella, Local 5 Oral History Project, 8-11.

${ }^{22}$ Cannarella, Local 5 Oral History Project, 8-11.

${ }^{23}$ Winzig, Local 5 Oral History Project, 11-12.
} 
stated. ${ }^{24}$ Similarly, Jeff Hensley concluded that rather than strike fear in the hearts of employees, Amburgey's caustic and obstructionist behavior in front of large groups activated and polarized the workers "marginally interested" in the contract around the union's bargaining committee. ${ }^{25}$ For these reasons, bookseller Jim Cowing counted Amburgey as one of the union's "greatest assets in holding the bargaining unit together." 26

Amburgey's bargaining approach not only strengthened the resolve of union activists but proved a key influence in turning previously anti-union workers into union supporters and leaders. Winzig credited the attorney's behavior for inspiring important discussions about work, class, and capitalism among employees. ${ }^{27}$ Similarly, Zartman described the bargaining sessions as a "wake up call" that brought to light the power dynamics previously obscured. ${ }^{28}$ Reichstein and Schafer credited the open bargaining and the witnessing the behavior of a lawyer selected by Michael Powell as a decisive factor in swaying fence sitters to support the union. ${ }^{29}$ Several of these workers, who Schafer recalled voted against the union, later became active members and officers, were "completely swayed by watching the way this lawyer talked to workers across the table." $" 30$

${ }^{24}$ McMahon, Local 5 Oral History Project, 6.

${ }^{25}$ Jeff Hensley, interviewed by Edward Beechert, Local 5 Oral History Project, ILWU Library, November 19, 2001, 10-13.

${ }^{26}$ Cowing, Local 5 Oral History Project, 7-9.

${ }^{27}$ Mary Winzig, interviewed by Harvey Schwartz, ILWU Oral History Collection, ILWU Library, June 11, 2001, Tape 3-4, 8-12.

${ }^{28}$ Mary Zartman, interviewed by Edward Beechert, Local 5 Oral History Project, ILWU Library, April 12, 2002, 4-7.

${ }^{29}$ Reichstein, Local 5 Oral History Project, 9.

${ }^{30}$ Schafer, Local 5 Oral History Project, 10-12. 
Cowing, who had previously penned an oppositional letter to the union's living wage argument during the recognition campaign, found himself engaged in a heated argument with Powell's lawyers over the subject. "I sort of gave a whole bunch of people a shot in the arm," reflected Cowing on the incident that culminated with him pounding his fist into the table and warning Amburgey not to underestimate the union. ${ }^{31}$ Such events as this illustrated what Carole Reichstein described as her fellow booksellers' “collective anger" towards Amburgey and his persistent belittling of booksellers and their demands. ${ }^{32}$ Although Amburgey's behavior proved agitational, the lawyer absorbed a portion of anger from booksellers that would otherwise have been directed at Powell's management. ${ }^{33}$

\section{Booksellers Take Action as a Union}

Local 5's ability to conduct an array of creative actions with varying levels of intensity and militancy, allowing workers to participate in a manner that matched their comfort level and encouraged them to take on bolder actions, represented a major factor in the union's success. The workers' gradual escalation of tactics and scale began with management's firing of bookseller and union activist Marty Kruse in October 1999. During a series of disciplinary meetings, Kruse evoked his legal right to have a union representative in the meeting. Fellow bookseller and communication steward Jen Dahlstrom and Cannarella attended the meetings and witnessed the firing. As Kruse left the store, an employee announced, "We love you, Marty" over the store intercom. ${ }^{34}$ The

\footnotetext{
${ }^{31}$ Cowing, Local 5 Oral History Project, 7-9.

${ }^{32}$ Reichstein, Local 5 Oral History Project, 6-9.

${ }^{33}$ Winzig, ILWU Oral History Collection, Tape 3-4, 8.

${ }^{34}$ Kevin Sampsell, "In Memoriam: Marty Kruse," April 2, 2012, Kevin Sampsell, https://kevinsampsell.com/2012/04/02/in-memoriam/.
} 
termination served as a catalyst for Local 5 to initiate a direct-action campaign to impact Powell's Book economically, as union members seemed to grow bolder with every job action.

The escalation of direct actions began one week after Kruse's termination with a modest rally. On October 27, Powell's employees gathered outside the City of Books front doors for a "break out," which preceded Kruse filing an Unfair Labor Practice (ULP) with the National Labor Relations Board (NLRB) ${ }^{35}$ The ten minute ULP strike "broke the ice for a lot of people," recalled Cannarella. ${ }^{36}$ Staff organizer Anissa Couey summarized the importance of the legally protected ULP strike with a metaphor, comparing the tactic to the feather in Dumbo's cap. ${ }^{37}$ Peter Olney, whose start in the labor movement came in 1973 as a worker-organizer in the United Electrical Workers (UE) union, noted that the Local 5 succeeded in coordinating an offensive reaction in order to temper the fear brought on by the termination. ${ }^{38}$ The escalation primed the union for forthcoming negotiating roadblocks. "Every time we had an action," recalled Meredith Schafer, "we brought them to the table more willing to deal." 39

Throughout the contract campaign, a consistent component of union activity centered on worker creativity and use of the written word. "We had enormous printing

\footnotetext{
${ }^{35}$ Marty Kruse, interviewed by Edward Beechert, Local 5 Oral History Project, ILWU Library, April 20, 2002, 10-16; Rein, Local 5 Oral History Project, 6-9; Takas, Local 5 Oral History Project, 9; "Local 5 Leader Marty Kruse Passes," The Dispatcher, May 2012, 6, 8. The NLRB decided that Marty Kruse's ULP charge held merit and the board negotiated a small financial settlement to compensate Kruse for the wages he lost due to his unemployment. Kruse left Portland shortly after his termination, but continued to work with books, including at AK Press in Oakland and The Booksmith in San Francisco. At Local 5's tenth anniversary in 2010, the union honored Kruse by bestowing upon him a lifetime union card and membership number "1." Kruse died from colon cancer at the age of 47 in 2012.

${ }^{36}$ Cannarella, Local 5 Oral History Project, 8-11.

${ }^{37}$ Olney, Local 5 Oral History Project, June 3, 2002, 16-18.

${ }^{38}$ Marcy Rein, interviewed by Harvey Schwartz, Local 5 Oral History Project, ILWU Library, June 14, 2002,16 .

${ }^{39}$ Schafer, Local 5 Oral History Project, 10-12.
} 
costs," recalled Cannarella, "We did a lot graphs, a lot of buttons, a lot of stickers, newsletters. ${ }^{, 40}$ In particular, stickers proved most popular among booksellers. ${ }^{41}$ Stickers "made people feel strong, part of group," stated Schafer. ${ }^{42}$ Workers also participated in rallies on the front porch of the store as well as "chalk outs" where workers would collectively write messages to customers and store management on the sidewalk that surrounded the store using sidewalk chalk. ${ }^{\mathbf{4 3}}$ Schafer also described getting union's message out to customers around the world by inserting union leaflets in books being prepared for shipping. ${ }^{44}$ Marcy Rein, in the ILWU's Communication Department, described a tension common to most campaigns regarding direct action tactics between those "who push the limits of dissent" and those "who want it to be very clear that they're acting within the legal limits." ${ }^{45}$ Success and unity depended upon Local 5's ability to balance these mutually shared but conflicted interests, not allowing either group to become disillusioned or marginalized.

Local 5's vigilant observance and application of its rights under the NLRA, specifically Sections 7 and 8, outmaneuvered Powell's management's efforts to dissuade support for the union during contract negotiations. Unlike strikes for economic demands, the NLRA protects employees' right to return to work without condition after a workstoppage over an Unfair Labor Practice (ULP). From the beginning, the ILWU took a proactive approach to preparing workers to confront management retaliation for union

\footnotetext{
${ }^{40}$ Cannarella, Local 5 Oral History Project, 15.

${ }^{41}$ Winzig, ILWU Oral History Collection, Tape 1, 35-38.

${ }^{42}$ Schafer, Local 5 Oral History Project, 8-10.

${ }^{43}$ Schafer, Local 5 Oral History Project, 8-10.

${ }^{44}$ Schafer, Local 5 Oral History Project, 8-10.

${ }^{45}$ Rein, Local 5 Oral History Project, 10-12.
} 
activity by educating booksellers on what constitutes an ULP and conducting trainings on their rights under Section 7 of the NLRA. ${ }^{46}$ At a January 2000 training, ILWU organizers highlighted that an effective use of Section 7 and 8 of the NLRA was necessary "to lay the legal basis for bringing home the contract" and to block any efforts by the employer to decertify the union. ${ }^{47}$ The local alertly filed complaints with the NLRB and took advantage of the union's right to strike under protection of labor law. Case in point, the ILWU filed a total of ten ULPs against Powell's management between October 1999 and May 2000, striking eleven times and receiving a favorable NLRB ruling in four of the charges. ${ }^{48}$ The bulk of ULP allegations were related to actions taken by managers at the City of Books, where booksellers used the ULP strike tactic and its legal protections to disrupt Powell's operations in hopes of leveraging concessions at the bargaining table.

The holiday season presented an opportunity for Local 5 to present its cause to throngs of shoppers, while simultaneously applying pressure upon Powell's management during its busiest and most profitable time. The union hoped that this public action could spur movement from the Powell's bargaining team, who had yet to bring any economic proposals to the table after twelve sessions over the two previous months. Furthermore, in mid-November, Powell's management made changes to the company's timekeeping policy. The unilateral change prompted Local 5 to file its second ULP, arguing that the

${ }^{46}$ Olney, Local 5 Oral History Project, June 3, 2002, 9-11; Winzig, Local 5 Oral History Project, 7-10; 29 U.S. Code § 157: "Employees shall have the right to self-organization, to form, join, or assist labor organizations, to bargain collectively through representatives of their own choosing, and to engage in other concerted activities for the purpose of collective bargaining or other mutual aid or protection."

${ }^{47}$ ILWU Local 5, "Building Workplace Power: Training Agenda," ILWU Library, ILWU Local 5 Document Archive, January 14, 2000. Cannarella, Local 5 Oral History Project, 11-14. ${ }^{48}$ ILWU Local 5, "NLRB Hits Powell's for Discrimination," ILWU Library, ILWU Local 5 Document Archive, July 18, 2000. 
move by the company violated an NLRB's mandate to maintain the status quo as it pertained to working conditions during contract negotiations. ${ }^{49}$

The ULP also set the stage for another strike. Booksellers expressed their disapproval with a walk-out and coordinated their first large scale action in partnership with the local labor community. On Black Friday, the day after Thanksgiving, booksellers began the day leafleting customers at the City of Books entrance, where booksellers later assembled for a ten-minute "break out." The workers were met by the labor folk band General Strike! and a mass of community supporters organized by the ILWU and Jobs with Justice. Bookseller Stephen Strausbaugh provided the crowd of longshoremen, teamsters, and carpenters, with an update on ULPs and contract bargaining as curious customers looked on while passing in and out of the store. Local 5 conducted a similar action later in the day at the Hawthorne store location, demonstrating that the union's activism spread beyond the downtown City of Books and Hoyt warehouse locations. ${ }^{50}$

\section{Bringing the "Spirit of Seattle" to Portland}

As Local 5 began contract bargaining and developed an action strategy to pressure Powell's Books to negotiate, progressive forces around the country planned to converge on Seattle, Washington to disrupt the World Trade Organization's (WTO) third ministerial conference. A coalition of environmental, labor, and human rights groups prepared to flood the streets of Seattle to protest the WTO's neoliberal international trade

\footnotetext{
${ }^{49}$ ILWU Local 5, “We Move Closer on Wages," Bridges to Bargaining, ILWU Library, ILWU Local 5 Document Archive, July 18, 2000, 2; In July 2000, the NLRB ruled in the favor of the union and stated that management's actions were an attempt to undermine the union's credibility with the workforce.

${ }^{50}$ ILWU Local 5, "Local 5 Launches Holiday Season with a Rally," Bridges, ILWU Library, ILWU Local 5 Document Archive, March 1, 2000, 3.
} 
agenda. Portland Jobs with Justice helped mobilize six thousand Oregonians, the majority of whom were from interfaith and social justice organizations including Local 5, for the trek to Seattle to join tens of thousands of other protesters for nine days of action between November 26 and December 3, 1999. ${ }^{51}$ Nancy Hoque, a Portland staffer for Jobs with Justice, was one of about five hundred demonstrators detained or arrested during a protest marked by the police's use of tear gas, rubber bullets, and mistreatment of demonstrators while in custody amid property damage by some protesters in the downtown business district.

Local 5, through the attendance of twenty-plus booksellers at the WTO protests, participated in one of the union's first actions not directly related to its organizing campaign and demonstrated the desire of participants to join forces with the broader labor movement. As a union highly involved in international trade, the ILWU and its local memberships took an unambiguous oppositional stance to the WTO. The longshore workers shut down North America's West Coast ports for the day as 1,500 of its members participated in a Labor March and Rally in Seattle, where Brian McWilliams addressed 30,000 fellow unionists. The disturbances outside of the conference and the subsequent international attention compounded differences between the developing and developed countries inside the ministerial, resulting in a failure to agree upon a series of multilateral trade agreements. Subsequently, conference chairperson and U.S. Trade Representative Charlene Barshefsky announcing a "time out," prompting many in the

\footnotetext{
51 "Margaret Butler on the Founding of ILWU Local 5." YouTube video, 18:02, posted by "ilwulocalfive," October 24, 2012, https://youtu.be/4jeWAXojrug; WTO Accountability Review Committee, "History/Timeline," History, accessed October 2, 2017, http://www.seattle.gov/archive/wtocommittee/history.htm\#sat2.
} 
anti-globalization movement to claim victory. ${ }^{52}$ "One of the results of doing this work," recalled Margaret Butler of Jobs with Justice, "was lots and lots of young energy coming into the struggles that we were taking on including the Powell's struggle." ${ }^{53}$ Whatever the outcome of the protests, demonstrators from around the country returned home with the intention of bringing the "Spirit of Seattle" to their local struggles. ${ }^{54}$

In the months following the WTO protests, the Powell's union struggle became a focal point for the city's progressive organizations just as the union's need for mutual aid and solidarity became most necessary. While the relationship between Local 5 and Portland's progressive community began during the union's recognition campaign, the union's newsletter reported in March that "the ties forged in Seattle at the WTO have remained here with us in Portland." ${ }^{55}$ When AT\&T relocated a union telecommunication office two blocks from Powell's Books to Texas, Local 5 booksellers joined the displaced workers on the picket lines. ${ }^{56}$ The resulting interplay between the union and social justice organizations produced informative and interactive solidarity actions at the bookstore that helped broaden the Powell's struggle from a private union issue to a community campaign. Case in point, Local 5 and its community partners conducted a "Christmas Carnival" inside the City of Books a week before the holiday and the day after the union

\footnotetext{
${ }^{52}$ World Trade Organization, "3 December - The Final Day and What Happens Next," WTO Briefing Note, accessed October 2, 2017, https://www.wto.org/english/thewto_e/minist_e/min99_e/english/about_e/resum03 e.htm; WTO Accountability Review Committee, "History/Timeline," History, accessed October 2, 2017, http://www.seattle.gov/archive/wtocommittee/history.htm\#sat2.

53 "Margaret Butler on the Founding of ILWU Local 5," https://youtu.be/4jeWAXojrug.

${ }^{54}$ Don McIntosh, "Labor Rally Opens America's Eyes to the WTO," Northwest Labor Press, December 17, 1999, https://nwlaborpress.org/1999/12-17-99WTO.html.

${ }^{55}$ ILWU Local 5, "Holiday Festivities, Art \& Revolution and Community Support on Dec. 18th," Bridges, ILWU Library, ILWU Local 5 Document Archive, March 1, 2000, 5.

${ }^{56}$ Brian McWilliams, interview by Madelyn Elders, Labor Radio, 90.7 KBOO FM, KBOO Community Radio Archive, Portland, Ore., Tape \#10-1216, March 11, 2000.
} 
filed its third ULP charge against Powell's. In conjunction with the ULP, moreover, Powell's employees at the Hoyt Street warehouse walked out again asserting that management violated the status quo by making unilateral changes to employees' schedules.

The Christmas Carnival gave community organizations the opportunity to demonstrate their support for Local 5 to both Powell's management and rank-and-file employees. Much of the character of the event derived from the Art \& Revolution Collective, whose members contributed an adaptation of Dr. Seuss's How the Grinch Stole Christmas! that included "Mr. Pool's Planet of Books." The action also invited customers, many of whom wore stickers stating how many years they had shopped at Powell's, to express their support for a fast and fair contract directly to store management. Meanwhile, a union chorus and labor folk band played both union songs and holiday carols inside the store as the Teamsters' tractor-trailer continually circled the store playing holiday songs. Over two hundred community allies participated in the action, which concluded with a march through the store demanding a contract for the booksellers. ${ }^{57}$

The December action represented a major escalation in Local 5's response to Powell's stalling at the bargaining table and prepared the workforce for future labor and community involvement on the booksellers' behalf. Nevertheless, Mary Winzig recalled that the presence of so many people from the public disrupting the store annoyed some booksellers, who thought the Powell's employees did not need any outside help. ${ }^{58}$

\footnotetext{
${ }^{57}$ ILWU Local 5, "Holiday Festivities, Art \& Revolution and Community Support on Dec. 18th," 5.

${ }^{58}$ Winzig, ILWU Oral History Collection, Tape 3-4, 13-17.
} 
Bookseller Jeff Hensley agreed that some workers felt the carnival action was "over the top," but concluded the action was effective for creating disorder for management and compelling their bargaining team to negotiate.$^{59}$ Turning the tables on the union, Powell's Books filed a ULP against Local 5 for disrupting business. The NLRB sided with the bookstore several months later giving no merit to the union's counter argument that the store achieved record high sales the same day as the rally. ${ }^{60}$ Yet, within a week after the holiday action, Powell's management brought its first compensation counter proposal to a bargaining session attended by twenty-five employee observers. Among the differences between the two economic proposals, Powell's proposed a $\$ 6.63$ starting wage to the union's proposal of $\$ 7.00 .{ }^{61}$

Despite some progress made in narrowing the difference on wage proposals, bargaining sessions in January 2000 proved increasingly contentious. In response to Powell's compensation plan, health care proposal, and management's rights clause, the union declared a "philosophical difference" with its employer. ${ }^{62}$ The management's rights clause was at the center of the tension. As Burnside bookseller Robert Gerke stated, the "union is asking to be partners in making decision and you (the Corporate Team) are saying that you want to call all the shots and run things. ${ }^{93}$ Powell's bargaining position divided issues into two boxes, those that were bargainable (wages and benefits) and those topics that were exclusively the right of management (the labor process). "We

\footnotetext{
${ }^{59}$ Hensley, Local 5 Oral History Project, 7-10.

${ }^{60}$ ILWU Local 5, "We Move Closer on Wages," 2.

${ }^{61}$ ILWU Local 5, "Number 7, Bargaining Sessions: Dec. 22, 1999 \& Jan. 5 2000," Bargaining Update, ILWU Library, ILWU Local 5 Document Archive, January 10, 2000.

${ }^{62}$ ILWU Local 5, "Number 8, Bargaining Session: January 13 \& 19, 2000," Bargaining Update, ILWU Library, ILWU Local 5 Document Archive, January 24, 2000.

${ }^{63}$ ILWU Local 5, "Number 8, Bargaining Session: January 13 \& 19, 2000," Bargaining Update, ILWU Library, ILWU Local 5 Document Archive, January 24, 2000.
} 
shouldn't be obligated to bring everything to staff," stated Human Resources Manager Sylvie Horne. ${ }^{64}$ "It's only about clarifying management's role. If we don't take on that responsibility, we're not doing our jobs," explained Corporate Manager Ann Smith. ${ }^{65}$ Michael Powell speculated that the union intended to run his store like a co-op. ${ }^{66}$ Management demonstrated that they, too, could protest by cancelling a scheduled bargaining session with only a day's notice, stating "It seems clear to the company's team that absent a significant breakthrough [...], we could shortly be at impasse. ${ }^{967}$ As management continued its stalling tactics, workers and their community allies continued to respond with increasingly larger and more disruptive actions.

Valentine's Day 2000 proved bittersweet for Michael Powell as Local 5 and its community allies began to demonstrate that they held Powell himself responsible for the prolonged contract negotiations. Powell's Corporate Manager Ann Smith refuted the union's claim that her side was intentionally dragging out negotiations, pointing to the fact that it took the union five months following the election to initiate bargaining. "We're not stalling," Smith told Publisher's Weekly, explaining that in December Powell's presented its wage and health care proposals and presented all proposals by mid-January. ${ }^{68}$ By February, however, the trust between the two sides was at a punctuated low as the union claimed management had attempted to spy on the bargaining

${ }^{64}$ ILWU Local 5, "Number 8, Bargaining Session: January 13 \& 19, 2000," Bargaining Update, ILWU Library, ILWU Local 5 Document Archive, January 24, 2000.

${ }^{65}$ Herochik, "Powell's Contract Negotiations Following an Old Script," The Business Journal, March 3, $2000,55$.

${ }^{66}$ Gail Kinsey Hill, "Powell's Contract Discussion Still Lagging," Oregonian, March 24, 2000, C01.

${ }^{67}$ ILWU Local 5, "Number 9, Bargaining Sessions: January 26th, February 1st, 7th, \& 16th," Bargaining Update, ILWU Library, ILWU Local 5 Document Archive, February 22, 2000.

${ }^{68}$ Kevin Howell and Roxanne Farmanfarmaian, "Booksellers Walk Out at Powell's," Publishers Weekly February 28, 2000, 28. 
committee by having a new manager attend the bargaining session and eavesdrop on the union's caucus sessions. ${ }^{69}$ Consequently, Local 5 filed a ULP on February 11 that provided legal protection for a work stoppage that coincided with a planned preValentine's Day demonstration the following day. Anissa Couey, hired on to the ILWU staff to support the organizing campaign, choreographed and implemented the Valentine's Day themed action by coordinating support from the Art \& Revolution Collective. ${ }^{70}$ In a repeat performance of the Christmas Carnival, the labor community, including Jobs with Justice, the Teamsters and union carpenters, joined the activist artists at the rally to demonstrate solidarity for the union book clerks. ${ }^{71}$

The pre-Valentine's Day "street party," as the union described the event, disrupted Powell's business in a manner characteristic of the "Spirit of Seattle.",72 Bookseller and community allies began to assemble at the store's main entrance carrying Jobs with Justice picket signs, red ILWU balloons, and makeshift drums. While bookseller Mary Winzig led a contingent of union carpenters to join the rally, John McMahon took to the megaphone to address the crowd of over seventy-five booksellers and over three hundred community allies. The Teamster's semi-truck repeated its winter holiday performance, circling the store and blowing its horn. "We've been showing our love to Michael Powell for a long time," stated McMahon, playing on the Valentine's Day theme. "As you can see, we have a big building that our love helped build,"

\footnotetext{
${ }^{69}$ Winzig, ILWU Oral History Collection, Tape 3-4, 13-17.

${ }^{70}$ Olney, Local 5 Oral History Project, June 3, 2002, 16-18.

${ }^{71}$ Winzig, ILWU Oral History Collection, Tape 3-4, 12.

${ }^{72}$ Michael Cannarella, Anissa Couey and Tricia Schultz, "Hundreds of Powell's Customers Plan PreValentine's Day Street Party," Media Advisory, ILWU Library, ILWU Local 5 Document Archive, February 22, 2000.
} 
connecting his fellow booksellers' labor to the recent City of Books expansion and Michael Powell's personal real estate success, "He owns several buildings downtown that we funded with our love." ${ }^{, 73}$ Previously, at a recent bargaining session, the management team had acknowledged that the end of 1999 brought "banner sales" to the company. However, Powell's argued that expenses had also increased, including the rent brought on by the downtown store's expansion. ${ }^{74}$ In a handbill for the Valentine's Day action, the union took issue with the "rent went up" argument by drawing attention to the fact that Powell's Books paid rent to the bookstore's owner Michael Powell, who owned the Burnside store, Hoyt Warehouse, Tech Store, and corporate office building properties. ${ }^{75}$ Local 5 countered Powell's rent dilemma with their own "Book Store Blues," a song penned by a bookseller for the union's demonstrations. The song's chorus bemoaned how Powell's employees “may not starve, but we'll always be poor” working at a bookstore, explaining that:

Rents are risin' every day, Rich folks come take our homes away, Can't afford to buy our homes ourselves, Can't even afford the books we shelve. ${ }^{76}$

73 “02 24 00,” YouTube video, 1:09:06, posted by “ilwulocalfive,” November 16, 2012, https://youtu.be/BLGF2O1Qbrw.

${ }^{74}$ ILWU Local 5, "Number 9, Bargaining Sessions: January 26th, February 1st, 7th, \& 16th," Bargaining Update, ILWU Library, ILWU Local 5 Document Archive, February 22, 2000.

${ }^{75}$ ILWU Local 5, "Progress of Contract Negotiations at Powell's," leaflet, ILWU Library, ILWU Local 5 Document Archive, February 12, 2000.

${ }^{76}$ Beth, "Book Store Blues," lyrics, ILWU Library, ILWU Local 5 Document Archive, 2000. 
As McMahon led a rhetorical chant of "Where's Michael Powell?", drawing attention to the fact that the owner had refused to attend the bargaining sessions, a twenty-foot-tall puppet of Powell appeared from around the corner of Southwest Oak Street. ${ }^{77}$

The symbolic street theater wedding between figures of capital and labor communicated the union's goals to a public audience divided on an intensifying conflict smack dab in the city's so-called living room. Activists from the Art \& Revolution Collective constructed the larger than life puppet of Powell for a theatrical parodied wedding ceremony with a bearded "Larry the Longshoreman" puppet, dressed in a white dress and carrying a docker's hook. The art activists officiated the wedding, including an exchange of vows that articulated the union's goals and the barriers created by Powell's management: "I, Michael Powell, do take this worker to be joined with me in a union. [...]. I promise to support you in good times and in bad with fair wages based on Powell's financial success, in sickness and in health with a clear benefits package, and no take backs." The call and repeat chants between Art \& Revolution and the crowd continued with Larry vowing that "for better or for worse, I will assert my rights in the grievance process so long as good faith on the part of management shall last." After the Michael and Larry puppets embraced, the emcee reminded the gathering of the importance of the community to get involved and stay involved in the struggle. ${ }^{78}$

The rally then moved inside the City of Books, disrupting management's control of the store with music and dance. As Michael Cannarella led the rally into the store, he

\footnotetext{
77 “02 24 00," YouTube video, https://youtu.be/BLGF2O1Qbrw; Mary Winzig and Stephen Strausbaugh, "Powell's Workers Walk Out to Protest Unfair Labor Practices," Press Release, ILWU Library, ILWU Local 5 Document Archive, February 16, 2000

78 "02 24 00," YouTube video, https://youtu.be/BLGF2O1Qbrw.
} 
explained that the purpose was to show employees and management "the power of this community and the importance of this union contract to everybody in the Portland area." The rally split up inside the store, occupying both the Green and Orange rooms that contained the store's two checkout stations and entrances. There, attendees danced in the aisles as musicians led singalongs to "Solidarity Forever," "Which Side are You On?" and other classic union anthems. Some demonstrators carried "Ask Me" signs with pictures of Powell's Books bargaining team, designed to help community allies identify managers and press them on their bargaining positions. ${ }^{79}$ Following the store action, a delegation of Local 5 members and community supporters bussed across the river to Michael Powell's home residence in a well-to-do Mount Tabor neighborhood. The union supporters, full of confidence and resolve in their goals, delivered union Valentines to the obstinate boss and then ended the day claiming victory. ${ }^{80}$

A new volley of ULPs from both management and the union ensued following the February 12 demonstration, leading to another bookseller strike four days later. Management followed the action by filing a charge against the union for disrupting business, while the union charged that management had intimidated bookseller Kathy Cunningham from participating in the day of action. "Instead of negotiating," Stephen Strausbaugh said of Powell's management, "they'd rather try to undermine the union by coming down on union activists in the store." ${ }^{81}$ On February 16, sixty-five employees

\footnotetext{
${ }^{79}$ ILWU Local 5, “Ask Me; Sylvie Horn, Miriam Sontz, Ann Smith,” picket sign, ILWU Library, ILWU Local 5 Document Archive, 1999-2000.

80 “02 24 00," YouTube video, https://youtu.be/BLGF2O1Qbrw; Olney, Local 5 Oral History Project, 911 .

${ }^{81}$ Mary Winzig and Stephen Strausbaugh, "Powell's Workers Walk Out to Protest Unfair Labor Practices," Press Release, ILWU Library, ILWU Local 5 Document Archive, February 16, 2000; ILWU Local 5, "We Move Closer on Wages," Bridges to Bargaining, ILWU Library, ILWU Local 5 Document Archive, July 18, 2000; However, the NLRB later ruled in favor of management on both charges filed by the company:
} 
walked-out off the job on a ULP protected strike at multiple worksites to join another twenty booksellers attending a contract bargaining session. The action not only temporarily halted Powell's shipping department for the day but compelled management to walk-out of the bargaining session room after fifteen minutes, stating that they needed to return to the store to assist those still working their shifts. ${ }^{82}$ In addition to applying direct economic pressure on Powell's management by halting the labor process, the actions served as a consciousness raising moment for booksellers as well as another opportunity to learn to take bigger and bolder collective actions together. Bookseller Mary Zartman described the experience by stating that "When you see a manager kind of panic and you realize that they can't run the store without you," then you realize the important position of the bookseller in the labor process. ${ }^{83}$ "People were so excited to be doing something together," remembered Powell's internet service rep Jean-Paul Jenkins. $^{84}$

\section{Counter Organizing Movement}

Powell's employees who continued to oppose unionization remained hopeful that probability and time would soon lead to a union-free shop. As both the company and the union tried to sway booksellers to their respective side, some booksellers found the confrontational tactics of the labor movement troublesome and probed for a possible vote

upholding Powell's claim of business disruption and refraining from issuing a complaint on the matter of intimidation of Cunningham.

${ }^{82}$ Winzig, ILWU Oral History Collection, Tape 3-4, 12; ILWU Local 5, "Feb.16th - ULP Walkout," Bridges, ILWU Library, ILWU Local 5 Document Archive, March 1, 2000, 6; Mary Winzig and Stephen Strausbaugh, "Powell's Workers Walk Out to Protest Unfair Labor Practices," Press Release, ILWU Library, ILWU Local 5 Document Archive, February 16, 2000; Michael Cannarella, Anissa Couey and Tricia Schultz, "Hundreds of Powell's Customers Plan Pre-Valentine's Day Street Party," Media Advisory, ILWU Library, ILWU Local 5 Document Archive, February 22, 2000.

${ }^{83}$ Zartman, Local 5 Oral History Project, 4-7.

${ }^{84}$ Marcy Rein, "Powell's Talks Stick, Local 5 Kicks...," The Dispatcher, February 2000, 5. 
to decertify the ILWU as the union. The NLRB allows a union decertification election to occur if a year has passed since the union's election and the company and union have yet to sign a contract. Even though the NLRB bars employers from getting involved in decertification campaigns, Powell's management appeared to have the advantage of time as the one-year anniversary of the union's election victory loomed over Local 5's bargaining team. In March, talk around the bookstore of a decertification campaign compelled the union to seek legal counsel about strategies for defeating such an effort. ${ }^{85}$ Around the same time, union opponents began speaking openly to the Oregonian about their wishes to decertify Local $5{ }^{86}$ The union caught wind of the decertification campaign when an employee mistakenly forwarded an email about a loosely organized decertification campaign to union activist Meredith Schafer instead of assistant manager Meredith Schreiber. ${ }^{87}$ Under the name of Employees for an Independent Powell's, union opponents distributed fliers promoting a website and email address the group created other employees interested in decertifying the ILWU. ${ }^{88}$ The group's statement of goals (signed by sixteen employees) criticized the union's actions as "sabotage," echoed the pre-election management critique of the union as a third-party, and defended Michael Powell's character. ${ }^{89}$

In the end, however, union activists unanimously agreed that the decertification campaign failed because its proponents proved poor organizers. ${ }^{90}$ Cannarella stated that

\footnotetext{
${ }^{85}$ Bill Carder to Michael Cannarella, 8 March 2000, letter, ILWU Library, ILWU Local 5 Document Archive.

${ }^{86}$ Gail Kinsley Hill, "Powell's Contract Discussion Still Lagging," Oregonian, March 24, 2000, C01.

${ }^{87}$ Cowing, Local 5 Oral History Project, 16-17; Schafer, Local 5 Oral History Project, 12-15.

${ }^{88}$ Hudson, Local 5 Oral History Project, 6-8.

89 "Employees for an Independent Powell's," leaflet, ILWU Library, ILWU Local 5 Document Archive, 2000.

${ }^{90}$ Cowing, Local 5 Oral History Project, 16-17; Hudson, Local 5 Oral History Project, 6-8.
} 
the Powell's bargaining team informed him and Brian McWilliams at a meeting in May 2000 that the company had waited a year to begin serious negotiations in hopes that a decertification campaign could materialize. 91 "People who don't want a union," explained Schafer, "aren't very good organizers," adding that it was her belief that those who advocated for decertification held management aspirations. ${ }^{92}$ On the other hand, Schafer considered the increased numbers of employees participating in union actions as a sign of a greater identification of booksellers as workers. ${ }^{93}$ Yet, even if the campaign had collected signatures from 30 percent of the bargaining unit to trigger an election, the NLRB would have likely needed to resolve the outstanding ULP charges filed against the company before the decertification election could occur. Mary Winzig wrote to Powell stating that a decertification campaign would fail because the union had grown from its narrow election victory to represent the majority of booksellers. ${ }^{94}$ In fact, by March of 2000, Local 5 claimed that 70 percent of the workforce had signed a petition supporting its contract bargaining goals. ${ }^{95}$

\section{Unity within a Diversity of Tactics}

Local 5 embraced a strategy that sought to apply not only direct economic leverage on Powell's Books, but also social pressure on its owner through a diversity of creative actions. Michael Powell's refusal to attend bargaining session proved a point of friction for booksellers and the union. Therefore, the union decided that if Powell refused

\footnotetext{
${ }^{91}$ Cannarella, Local 5 Oral History Project, 8.

92 Schafer, Local 5 Oral History Project, 10-14.

93 Schafer, Local 5 Oral History Project, 14.

${ }^{94}$ Mary Winzig, "Bargaining Session: Friday, March 31st,” leaflet, ILWU Library, ILWU Local 5 Document Archive, March 31, 2000.

95 ILWU Local 5, “Decertification,” leaflet, ILWU Library, ILWU Local 5 Document Archive, 2000.
} 
to meet with them that the union would find him. Local 5 and ILWU President Brian McWilliams publicly confronted Powell at the Port of Portland's commissioners' meetings, where Powell refused to respond to the union and turned his back on the delegation. ${ }^{96}$ Soon thereafter, McWilliams issued a public invite to his corporate counterpart to join him at a bargaining session in the hopes that the two leaders could help overcome some of the obstacles slowing down contract negotiations. ${ }^{97}$ Months prior, the two men had crossed paths inside the bookstore and discussed both the bargaining standstill and the idea of jointly attending a bargaining session. ${ }^{98}$ Unmoved, Powell ultimately declined the invitation and the bargaining stalemate persisted.

While Powell and his bargaining team promoted its wage proposal as a $\$ 2.1$ million compensation plan, booksellers contended that the company's offer included several takeaways that redistributed compensation elsewhere to give the appearance of a larger economic package. Booksellers, including Cowing, considered management's proposal to discontinue paid lunches, holiday bonuses, and profit sharing disingenuous. ${ }^{99}$ In particular, the proposal to end the paid lunch practice created rancor among booksellers, who overwhelming wished to hold on to the pre-contract practice. Stacy

\footnotetext{
${ }^{96}$ As a governor appointed member of the commission, Powell's responsibilities included working with union leaders from the city's varied transportation infrastructure workforce. Nevertheless, Powell refused to meet with his union employees. Brian McWilliams, interviewed by Harvey Schwartz, Local 5 Oral History Project, ILWU Archive, San Francisco, Calif., July 19, 2002, 7-10; Mary Winzig, "Bargaining Session: Friday, March 31st," leaflet, ILWU Library, ILWU Local 5 Document Archive, March 31, 2000; Steve Dunn, At Least They're Copacetic on the Bulletin Board, Oregonian, March 12, 2000, D01.

${ }^{97}$ Michael Cannarella, Anissa Couey and Tricia Schultz, "International President Brian McWilliams Invites Michael Powell to the Table," Media Advisory, ILWU Library, ILWU Local 5 Document Archive, March 24, 2000.

${ }^{98}$ Brian McWilliams, interview by Madelyn Elders, Labor Radio, 90.7 KBOO FM, KBOO Community Radio Archive, Portland, Ore., Tape \#10-1216, March 11, 2000.

${ }^{99}$ Ann Smith to Staff Members, 21 April 2000, letter, ILWU Library, ILWU Local 5 Document Archive; Jim Cowing, "Some Clarifications about the Money Show - Part 3," ILWU Library, ILWU Local 5 Document Archive.
} 
Friedman argued in an article in the union's newsletter that agreeing to these tradeaways would be "foolish," adding that maintenance of these benefits is "self-evident and should go without saying." In order to overcome these bargaining barriers, Friedman stated that it was "more important than ever for us to increase the pressure on management to bargain fairly with us and quit presenting us with proposals they know are unacceptable." 100

The union initiated work stoppages and disrupted the company's shipping process by continuing to take advantage of Powell's management's anti-union behavior and the NLRB's ULP process. In mid-March, Local 5 filed its sixth ULP against Powell's. The union alleged that management's recent crackdown on timekeeping and lunch breaks deliberately targeted union supporters. In response, thirty workers conducted a work stoppage on St. Patrick's Day and were joined by a dozen members of ILWU Local 8 and other community allies. ${ }^{101}$ The strike provided booksellers the opportunity to experience the power of solidarity among workers outside of Powell's. UPS Teamster drivers and union postal workers respected the strike and refused to deliver or pick up packages, forcing management to make deliveries by driving to the post office. ${ }^{102}$ "We SHUT IT DOWN," boasted Wendy Brown in the shipping department. ${ }^{103}$ The strike "made everybody feel strong," recalled Mary Winzig after witnessing the solidarity of other workers. The success of the action "made us realize that we were the ones doing the work

\footnotetext{
${ }^{100}$ Stacy Friedman, “A Sucker's Bet for You: Management's Proposals as a Shortcut to an Inequitable Future," Bridges, March 1, 2000, 2.

${ }^{101}$ Marcy Rein, "Workers at Powell's and UltraEx Speak Loud to Power," The Dispatcher, April 2000, 3, accessed September 19, 2017, http://archive.ilwu.org/wp-content/uploads/2015/04/20000401.pdf. ${ }_{102}$ Cowing, Local 5 Oral History Project, 9-12; Reichstein, Local 5 Oral History Project, 10-13.

${ }^{103}$ Brandon Cotter, "The Turning Point," Bridges, May/June 2001, 4.
} 
and we could shut it down when we had to." 104 The union conducted its first all day work stoppage two days later when one-third of the Burnside store walked out to picket and leaflet customers outside the store. ${ }^{105}$

While the St. Patrick's Day strike proved a success in halting the shipping department's operations, discussion about the action the next day centered around what became known as the "tire incident." 106 Management found a tire on one of Powell's delivery van's deflated during the strike and attributed the act to the union, which denied any maleficence. "I will not be bullied," Powell told the Oregonian regarding his response to the March strikes. ${ }^{107}$ Powell's employee David Weich penned and distributed a public letter to fellow Burnside employees condemning the actions of "three goons, ILWU pawns," who disrupted the day's business. ${ }^{108}$ Ryan Thomas, Tech Store employee and signatory to the Employees for an Independent Powell's letter, took his opposition to the action public, submitting a Letter to the Editor of the Oregonian that denounced what he called "mob tactics" by the ILWU. ${ }^{109}$ The heightened attention over the slashed tire prompted the local to distribute a flier denouncing the "tire incident" and John McMahon to respond with a letter to his coworkers. ${ }^{110}$ McMahon attempted to re-center the discussion on the union's primary issue: Michael Powell's resistance to bargaining.

\footnotetext{
104 Winzig, Local 5 Oral History Project, 7-10.

105 Gail Kinsley Hill, "Powell's Workers Stage New Walkout as Dispute Drags," Oregonian March 20, 2000, E07.

${ }^{106}$ Cowing, Local 5 Oral History Project, 7-9.

107 Gail Kinsley Hill, "Powell’s Contract Discussion Still Lagging,” Oregonian, March 24, 2000, C01.

108 Nigel Jaquiss, “The Bookworms Turn,” Willamette Week, March 22, 2000.

${ }^{109}$ Ryan G. Thomas, letter to editor, Oregonian, March 27, 2000.

${ }^{110}$ ILWU Local 5, "Fellow Powell's Employees and Managers," leaflet, ILWU Library, ILWU Local 5 Document Archive, 2000.
} 
McMahon also took aim at the Oregonian's "over dramatized" coverage of the event, which misrepresented picket signs as "wooden sticks."111

Although Michael Powell refused to participate in bargaining, he communicated his perspective on the company's bargaining stance and goals for a first contract to customers and employees. In one letter to customers, Powell welcomed the involvement of a federal mediator to assist contract bargaining. Nevertheless, the bookstore owner reaffirmed his commitment for a detailed management's rights clause and his opposition to a union shop clause he framed as a "mandatory union fee" for employees, who he believed should "have a right to choose who they associate with and what organizations they support financially." ${ }^{112}$ Similar to the election phase, Powell continued to send letters with bargaining updates to employees' homes. "Every time management tries to do something 'smart,' more people come to our side," explained bookseller and communication steward Stephen Strausbaugh. ${ }^{113}$ Local 5's St. Patrick Day action compelled Powell to send out an all staff letter denouncing the "belligerent and unlawful behavior" of the union's action as "not consistent with the Powell's culture."114 Yet, this only prompted Mary Winzig to respond with her own open letter to Michael Powell, deriding the bookstore owner's updates about bargaining when he had yet to attend a negotiating session. ${ }^{115}$

\footnotetext{
${ }^{111}$ John McMahon to Co-workers, March 2000, letter, ILWU Library, ILWU Local 5 Document Archive.

${ }^{112}$ Michael Powell to Reader, 2000, letter, ILWU Library, ILWU Local 5 Document Archive.

${ }^{113}$ Dave Mazza, "Union Supporters Jam Powell's Again," The Portland Alliance, March 2000, 5.

${ }^{114}$ Michael Powell to Staff Member, 20 March 2000, letter, ILWU Library, ILWU Local 5 Document Archive.

${ }^{115}$ Mary Winzig, "Bargaining Session: Friday, March 31st," leaflet, ILWU Library, ILWU Local 5 Document Archive, March 31, 2000.
} 
While accumulating social pressure upon Michael Powell and direct economic action were the union's most effective tactics, Local 5's creative lower intensity actions kept the bargaining question ever present and provided different ways for booksellers to participate in the struggle. Stickers again proved popular among employees, this time with slogans regarding their bargaining demands, including "Hands off My Lunch." 116 The booksellers in the children's section led one of the most popular actions, conducting a ten minute "read-in" that featured the reciting of Click, Clack, Moo: Cows that Type (2000) by Doreen Cronin. The children's book tells the story of a group of cows who acquire better living conditions from a farmer by organizing a strike with the solidarity of the farm's hens and ducks. The union held several other read-ins in different sections of the store during the contract campaign. ${ }^{117}$ Bookseller Meredith Schafer recalled that these union actions "gathered a lot of attention and drove management crazy" because managers could neither predict nor prepare for when or where the actions would take place. ${ }^{118}$ The booksellers also utilized the store's intercom system for solidarity pages. An employee initiated a union "hug-in" one day at the City of Books with a page of "Harry Bridges to the Green Room." Such intercom pages calling for Harry Bridges, a founding leader of the ILWU, became calls for immediate collective action on the shop floor. ${ }^{119}$

Local 5 organizers sought to foment a social movement in Portland around its fight for a contract, in part, by providing opportunities for local activists in the emerging

\footnotetext{
${ }^{116}$ Marcy Rein, “Workers at Powell's and UltraEx Speak Loud to Power,” The Dispatcher, April 2000, 3, accessed September 19, 2017, http://archive.ilwu.org/wp-content/uploads/2015/04/20000401.pdf.

${ }^{117}$ Zartman, Local 5 Oral History Project, 7-11.

${ }^{118}$ Schafer, Local 5 Oral History Project, 8.

${ }^{119}$ Marcy Rein, "Workers at Powell's and UltraEx Speak Loud to Power," The Dispatcher, April 2000, 3, accessed September 19, 2017, http://archive.ilwu.org/wp-content/uploads/2015/04/20000401.pdf.; Jane Slaughter, ed., A Troublemaker's Handbook 2: How to Fight Back Where You Work and Win! (Detroit: Labor Notes Books, 2005), 13.
} 
anti-globalization movement to participate in the struggle. ILWU Organizing Director Peter Olney pointed to the fact that when Portland played host to the union's 31st International Convention in May, the Powell's campaign "was the number one story in the news." ${ }^{120}$ A series of high profile events in May and June showcased Local 5's effectiveness at organizing community support through open letters, stickers, pins and street actions. $^{121}$

At the same time, public opinion remained divided over Powell's union struggle, particularly among the segment of Portland's liberal and progressive populace that saw Michael Powell as a leading liberal benefactor, model business owner, and philanthropist. Frequently, Local 5's detractors described the grievances of the booksellers as "whining."122 This prompted Powell's employees to deride the media coverage of their struggle as too friendly to Michael Powell. Following the March work stoppages, "an emotional Powell" gave the Oregonian an interview about the slow progress in bargaining and the escalation of the union's actions. Powell complained of "going through all this pain" and being "hung out to dry" for not knowing all his employees' names. "Other than that," the bookstore owner confessed, "I don't know what I've done wrong." ${ }^{23}$ In an editorial entitled "Will the Union Ruin Powell's?", the Oregonian condemned ILWU tactics: "This may be the sort of thing you get used to out on the docks. Maybe even the bullhorns are necessary, what with all the ships and cranes and truck noise and such. But in a bookstore, it's just raw intimidation." The editors

\footnotetext{
${ }^{120}$ Olney, Local 5 Oral History Project, June 3, 2002, 13-16.

${ }^{121}$ Winzig, Local 5 Oral History Project, 11-12.

122 Mary Zartman, “Is This What it is?” Bridges, May/June 2001, 3.

${ }^{123}$ Gail Kinsey Hill, “Powell's Contract Discussions Still Lagging, Oregonian, March 24, 2000, C01.
} 
concluded that the dispute would leave Powell's, "the heart of the city," inevitably scarred. ${ }^{124}$

The public opinion battle continued the following week with two contrasting opinion pieces. Local 5 took aim at the Oregonian for its perceived collaboration with Powell and accused the newspaper of misrepresenting the booksellers' actions. In a jointly written editorial, Michael Cannarella and John McMahon, challenged the Oregonian's predisposition to silent protest over collective action, reminding the editorial staff that institutions involve collaborative efforts and not the product of one man. ${ }^{125}$ Alongside the union piece ran an editorial by Lynne Saxton, a former business associate of Michael Powell. Saxton echoed the Oregonian editorial by deriding the union's actions as a "circus of rhetoric and obstructionism" against an important local employer, asserting that Powell "deserves respect and civility for his commitments to his employees [...] and to his employees' interests." 126 The discourse regarding the conflict seeped into the Oregonian's Living Section, where staff writer Jonathan Nicholas explained why Michael Powell was winning the public opinion contest and why his struggle has created “pervasive civic sadness surrounding his situation.” Michael Powell, insisted Nicholas, represented "the embodiment of Portland's vaunted 'good citizen.",127

Opinions on the Powell's struggle also filled the editorial pages of the Portland Business Journal. In March, former labor history educator and SEIU administrator Shelly

\footnotetext{
124 “Will the Union Ruin Powell’s?” Oregonian, March 26, 2000, D04.

${ }^{125}$ Michael Cannarella and John McMahon, “A Union View of Michael Powell,” Oregonian, April 2, 2000, Editorial.

${ }^{126}$ Lynne Saxton, "Michael Powell Deserves Much Better," Oregonian, April 2, 2000, Editorial.

${ }^{127}$ Jonathan Nicholas, "Why Mike Powell Keeps Winning the Battle for City's Hearts and Minds," Oregonian, May 12, 2000 , E01.
} 
Herochik contended that the Powell's contract dispute differed little from bargaining in other economic sectors more frequently associated with labor disputes: "It's business as usual at the Powell's Books bargaining table," Herochik noted. ${ }^{128}$ Yet, she pointed to the inexperience of the two bargaining teams as a contributing factor to the lengthy negotiations and escalation of tactics. ${ }^{129}$ The article compelled attorney Larry Amburgey, the most experienced negotiator on the corporate team, to respond two weeks later. "I am for the first time in my 25 years representing employers compelled to respond to a media article related to negotiations in which I am involved," explained Amburgey. ${ }^{130}$ After interviewing Local 5's bargaining team members, Herochik had quoted Amburgey lecturing the union on the negotiating process: "This is how it works. We put things on the table and you agree." Powell's lawyer now refuted this claim and insisted that the company "is trying its best to find common ground with the union." 131

Three months later, Business Journal publisher Mike Consul backed "Mike" Powell by editorializing that the bookstore owner and the city of Portland deserved better than the actions taken by the union. Consul twice recommended that Powell's employees should "kick out the union" and "call off the war," describing a union movement that feared change, globalization, and the "new economy." Instead, Consul called for disaffected employees to show "some entrepreneurial initiative or independence" and open their own bookstores. ${ }^{132}$ The editorial received criticism from two readers, who

\footnotetext{
128 Twiford Funeral Homes, "Shelly Herochik," obituary, published January 16, 2009, accessed September 20, 2017, https://www.twifordfh.com/shelley-herochik/; Herochik, "Powell's Contract Negotiations Following an Old Script," 55.

${ }^{129}$ Herochik, "Powell's Contract Negotiations Following an Old Script."

${ }^{130}$ Larry Amburgey, "Re: Powell's Coverage,” The Business Journal, March 17, 2000.

${ }^{131}$ Larry Amburgey, "Re: Powell's Coverage," The Business Journal, March 17, 2000.

${ }^{132}$ Mike Consol, "Powell Has Paid His Union Dues," The Business Journal, June 2, 2000.
} 
contributed letters to the editor in the weeks that followed. "If it weren't for the workers," wrote Douglas Theriault of Portland, "Michael Powell would have nothing!!!"133 North Portlander Misha Wilson challenged Consul's conclusion that the Powell's booksellers should have opened their own stores instead of unionizing, writing of Consul that "he obviously lives in a different world than the world I live in-different, most probably, than the world inhabited by most workers employed in the low-paid service industry." 134 Portland's alternative news weekly, Willamette Week, did not portray the labor dispute any better for the union. Investigative reporter Nigel Jaquiss' feature article on the contract struggle, "Powell's a City Divided," sought to uncover what issues were at the root of the labor struggle within one of Portland's favorite institutions. Jaquiss concluded that while the store would likely survive the contract dispute, the culture that made the store an institution was at threat. ${ }^{135}$ In assessing the economic issues at stake, Jaquiss concluded that because of the wages (at an average of $\$ 9.00$ per hour) and benefits (including purported use of Michael Powell's beach house), the booksellers were "well-compensated." The article described the workplace as a "replicated campus life -minus tuition," where employees were the benefactors of "indulgent bosses and subsidized coffee." 136 While Jaquiss described the ILWU as "one of the most aggressive outfits in the labor movement," the reporter portrayed Michael Powell as a wellintentioned philanthropist, whose shy and quiet personality prevented him from

\footnotetext{
${ }^{133}$ Douglas Theriault, "Powell's Union Is Like Any Other Union: It Fights for Workers' Rights," Letters to the Editor, The Business Journal, June 16, 2000, 16.

${ }^{134}$ Misha Wilson, "Publisher Should Step Out of Glass Office and Level with Powell's Workers," Letters to the Editor, The Business Journal, July 14, 2000, 22.

${ }^{135}$ Nigel Jaquiss, "Powell's City Divided," Willamette Week, March 15, 2000.

136 Jaquiss, "Powell's City Divided."
} 
communicating with his employees. "Sometimes, at 2 a.m. I despair," Powell told the Willamette Week, describing how he had not slept well ever since the union drive began. "It's clear that somehow I failed in deed or in words to convince employees that their working conditions were the most important thing to me," he concluded. What led to the union at his store, he mused "was hard to internalize." 137

In the weeks that followed Jaquiss' article, booksellers and readers responded with letters airing either their disagreement with the piece or condemnation of the booksellers. Powell's employee Cal Hudson and Weekly reader Luke Anavi challenged Jaquiss' conclusion that booksellers were well compensated or even received a living wage. In the same issue as Jaquiss' article, Anavi pointed to the Powell's help-wanted ad that advertised a starting hourly rate of $\$ 6.50$, the state's minimum wage. ${ }^{138}$ While Powell's employees Karin Dibling, Matt Baker, and Melissa Mae Anthony joined Hudson in challenging the negative characterization of union supporters and providing testimony for the union's' economic demands, other readers condemned the booksellers as over-educated, ungrateful whiners. "Powell's workers should be ashamed of themselves," wrote J.P Davidson of Southeast Portland. "As a liberal I am tired of whining, self-interested 'cause hawks' who exist to protest and protest to exist," declared Davidson. ${ }^{139}$ Other readers questioned why the employees did not find other jobs if they were so unhappy at Powell's. Reader Ron Williams wrote that maybe the unappreciated workers would find a better job, "if they put Mom and Dad's tuition money to use, sent

\footnotetext{
${ }^{137}$ Jaquiss, "Powell's City Divided."

${ }^{138}$ Luke Anavi, "Living for the City," Letters, Willamette Week, March 22, 2000.

139 J.P. Davidson, "Cause and Defect," Letters, Willamette Week, April 5, 2000.
} 
out a few resumes and bought some decent clothes." ${ }^{140}$ In response, Karin Dibling asked who in society deserved a living wage and secure retirement? "Someone has to do the grunt work in our society," argued Dibling, "and if anything they deserve a secure future more than the suits do."141

ILWU organizers and Local 5 booksellers assembled a media strategy that relied on telling workers' stories through grassroots, rather than mainstream media outlets. The ILWU assigned Marcy Rein, an experienced writer and organizer to spearhead this campaign. "We started out really behind," recalled Rein, acknowledging the glistening reputation Michael Powell had garnered over the past two decades. Rein, who wrote numerous campaign updates for the ILWU's newspaper The Dispatcher, understood the correlation between how the union portrayed the booksellers' struggle and how much pressure Powell received from the community. ${ }^{142}$ Rather than emphasis how the booksellers were uniquely special for their literary expertise in press releases and interviews, Rein knew that in order to connect with the public the booksellers' needed to share personal stories about how the company's working conditions impacted their lives as workers, neighbors, and Portlanders.

Local 5 utilized Portland's grassroots media outlets, such as KBOO Community Radio and The Portland Alliance newspaper, to get their message "out over" critical media, as described by John McMahon. ${ }^{143}$ Both McMahon and Kruse cited the vital role $\mathrm{KBOO}$ played in getting the union's message through to the station's progressive

\footnotetext{
${ }^{140}$ Ron Williams, "Turn the Page," Letters, Willamette Week, March 29, 2000.

${ }^{141}$ Karin Dibling, "Portland's Living Wage," Letters, Willamette Week, April 19, 2000.

${ }^{142}$ Rein, Local 5 Oral History Project, 6-9.

${ }^{143}$ McMahon, Local 5 Oral History Project, 8-9.
} 
audience. ${ }^{144}$ Nevertheless, rather than dismissing the mainstream media altogether, the union met with the Oregonian's editorial staff about the cause and penned opinion pieces published by the newspaper. ${ }^{145}$ At the same time, the union took its message to progressive readers around the country, purchasing space in The Nation magazine in April. ${ }^{146}$ Nearly 70 percent of the workforce, 263 employees, signed their names to a letter calling upon readers to voice their support for Local 5 directly to Michael Powell. ${ }^{147}$ The ad drew criticism from Willamette Week reporter Nigel Jaquiss, who charged that the union had falsely calculated claims regarding Powell's profitability. ${ }^{148}$ However, Shelley Herochik had referenced the same figure in her article for the Portland Business Journal three months before Jaquiss' challenge, citing business information leader Dun \& Bradstreet as her source. ${ }^{149}$

The protracted contract struggle led some segments of the ILWU, including some international officers, to question the amount of union resources provided to a retail workers struggle. Yet President Brian McWilliams was determined to win stating that, "Whatever they asked me for, we provided." ${ }^{150}$ While the Local 5 booksellers worked double time, the ILWU contributed a considerable number of staff and attorney hours to the campaign. In addition to Peter Olney's and McWilliams' time spent on the campaign and bargaining, Michael Cannarella worked full time on the campaign alongside two full-

\footnotetext{
${ }^{144}$ Kruse, Local 5 Oral History Project, 10-14.

145 McWilliams, Local 5 Oral History Project, 10-15.

146 Winzig, Local 5 Oral History Project, 11-12.

${ }^{147}$ Marcy Rein, “Workers at Powell's and UltraEx Speak Loud to Power," The Dispatcher, April 2000, 3 , accessed September 19, 2017, http://archive.ilwu.org/wp-content/uploads/2015/04/20000401.pdf; Michael Cannarella, "Forbes Touts Powell's Profitability as Contract Talks Stall," Press Release, ILWU Library, ILWU Local 5 Document Archive, April 20, 2000.

148 Nigel Jaquiss, "Wrong Numbers," Willamette Week, May 3, 2000, 15.

${ }^{149}$ Herochik, "Powell's Contract Negotiations Following an Old Script," 55.

${ }^{150}$ McWilliams, Local 5 Oral History Project, 7-10.
} 
time and one half-time ILWU project staff. Furthermore, Cannarella described "enormous printing costs" for the union, which he attributed to the culture of the workforce that necessitated a constant flow of written material. ${ }^{151}$ Subsequently, as ILWU members scrutinized the costs of the Powell's Books campaign in the lead-up to the union's officer elections in May, the longshore workers' continued investment in Local 5 appeared uncertain. ${ }^{152}$

${ }^{151}$ Cannarella, Local 5 Oral History Project, 14-16.

${ }^{152}$ Olney, Local 5 Oral History Project, 18-21. 


\section{Chapter 5}

\section{“We Can Shut It Down": May Day 2000}

Portland's labor community remained steadfastly behind the Powell's booksellers' struggle. ILWU Local 8 proved a reliable supporter, "They kind of liked the idea that the longshore was moving inland," recalled Peter Olney, "They liked the idea of working with these young people." Labor activists and educators within the local community also continued to provide their services to the new local. The University of Oregon's Labor Education \& Resource Center (LERC) organized a "Union 101 Class" following the election for the new union members. Carole Reichstein attended this class and caught the attention of the mostly Burnside employees because of her previous opposition to the union at the Tech Store employee. Reichstein's change in position also caught the attention of other Tech Store employees; she described it as a "big deal" among her coworkers when she switched from wearing an anti-Local 5 pin to a union pin. ${ }^{2}$ Fittingly, the labor movement and anti-globalization advocates demonstrated their solidarity in a manner that appeared to infuse both the newly emerged "Spirit of Seattle" and the union movement of the 1930s on International Workers' Day.

\section{ILWU Convention and May Day}

The events of May Day 2000 and a Workers' Rights Board hearing organized by Jobs with Justice the following month represent the two factors union activists held most responsible for the shift in momentum to Local 5 and the jumpstart in the stalled contract

\footnotetext{
${ }^{1}$ Peter Olney, interviewed by Harvey Schwartz, Local 5 Oral History Project, ILWU Library, June 3, 2002, 7-9.

${ }^{2}$ Carole Reichstein, interviewed by Edward Beechert, Local 5 Oral History Project, ILWU Library, April 17, 2002, 4-6; Carole Reichstein, "Confessions of a (former) Local 5 Buster: Part Two, Union 101 Class," Bridges, ILWU Library, ILWU Local 5 Document Archive, March 2002, 2.
} 
bargaining. The World Trade Organization (WTO) protests seemed to breathe life into the moribund May Day holiday as Portlanders who participated in the Seattle demonstrations sought to carry on the anti-globalization struggle at home. In response to anarchist activity and instances of property destruction in Seattle, cities and police departments across the country, including Portland's law enforcement officers under the new leadership of Chief of Police Mark Kroeker, prepared for unruly demonstrations. ${ }^{3}$ "We are in a new era of public protest and police response to protests $[\ldots]$ and Seattle was the catalyst," stated City Commissioner Dan Saltzman shortly after Portland's May Day. ${ }^{4}$ Incidentally, the ILWU had scheduled its international convention, held in May every three years within a rotating host state on the West Coast, for Portland in 2000. Thus, as bargaining remained at a standstill, the booksellers made sure that their union's cause took center stage during the city's International Workers' Day celebrations. ${ }^{5}$

May Day and the subsequent actions that followed exemplified the union adage that "the street drives the table," meaning that how workers use public action determines if management makes concessions. ${ }^{6}$ In fact, Larry Amburgey --Powell's experienced contract negotiator and attorney-- understood this dynamic as well as his ILWU bargaining counterparts. When the union warned Amburgey that five hundred longshore

\footnotetext{
${ }^{3}$ Mark Kroeker, who previously worked for thirty-two years in the Los Angeles Police Department, was hired by Portland Mayor Vera Katz to the city's Chief of Police position in August 1999. During the city council and community meetings that followed the May Day confrontations, critics levied fault upon Kroeker's leadership and tactical decisions.

${ }^{4}$ Robin Franzen, "No Clashes Mar Union March, Rally," Oregonian, May 5, 2000, A01.

${ }^{5}$ Olney, Local 5 Oral History Project, June 3, 2002, 22-24; Marcy Rein, interviewed by Harvey Schwartz, Local 5 Oral History Project, ILWU Library, June 14, 2002, 10-12; Mary Winzig, interviewed by Harvey Schwartz, ILWU Oral History Collection, ILWU Library, June 11, 2001, Tape 3-4, 17-20; Jeff Hensley, interviewed by Edward Beechert, Local 5 Oral History Project, ILWU Library, November 19, 2001, 13-14; Brian McWilliams, interviewed by Harvey Schwartz, Local 5 Oral History Project, ILWU Archive, July 19, 2002, 10-15.

${ }^{6}$ Olney, Local 5 Oral History Project, June 3, 2002, 25.
} 
workers in town for the ILWU Convention planned to visit Powell's Books expecting a signed contract between the two sides, Amburgey's response appeared dismissive of the union's capability: "If you feel you need to take it to the public or feel you can apply pressure in some other way, that's your prerogative."7 In an interview with KBOO in March, Brian McWilliams had conveyed a message that the ILWU international was preparing itself for just that sort of situation, stating that the union's convention activities might include some visits to Powell's. "Who knows," McWilliams speculated, "we may have the opportunity to go down and spend a lot of money and buy some books and enjoy shopping in an ILWU workplace or some other scenario may happen."8

Leaving nothing to chance, Local 5 and the ILWU prepared for the "other scenario" with their community and labor partners. Local 5 planned to occupy the space in front of the store for an afternoon rally and "Picnic for Justice" on Monday, May 1st, which would coincide with local International Workers' Day celebrations. While Art \& Revolution crafted puppets and 20-foot tall birds and flowers for the springtime festival, a team of radical cheerleaders planned to lead the chants for the booksellers. ${ }^{9}$ The union also planned to distribute solidarity postcards for customers to submit to Michael Powell, showing their support for the booksellers. True to form, the union filed an Unfair Labor Practice (ULP) with the National Labor Relations Board (NLRB) this time in response to

\footnotetext{
${ }^{7}$ Marcy Rein, "Workers at Powell's and UltraEx Speak Loud to Power," The Dispatcher, April 2000, 3, accessed September 19, 2017, http://archive.ilwu.org/wp-content/uploads/2015/04/20000401.pdf.

${ }^{8}$ Brian McWilliams, interview by Madelyn Elders, Labor Radio, 90.7 KBOO FM, KBOO Community Radio Archive, Portland, Ore., Tape \#10-1216, March 11, 2000.

${ }^{9}$ Marcy Rein, "Powell's Customers Plan May Day 'Picnic for Justice,"” Media Advisory, ILWU Library, ILWU Local 5 Document Archive, April 28, 2000.
} 
the promotion of an outspoken anti-union employee over union supporters with more experience and seniority in the shipping department. ${ }^{10}$

In preparation for May Day, Central Precinct Lt. Mike Crebs of the Portland Police Department met with Powell's Books management to discuss the upcoming demonstrations to take place in front of the downtown store. Following the meeting, Crebs met with Olney and other ILWU organizers, who asked the officer to close NW Tenth Avenue between West Burnside Street and NW Couch Street so Local 5 could hold its march, picnic, and rally. ${ }^{11}$ While Crebs agreed to the request, the police nonetheless planned to have eleven officers, including the Mounted Patrol Unit, present. ${ }^{12}$ Crebs attempted, but failed, to get information from the ILWU organizers about the individuals and organizations planning the May Day event. Instead, he received information about the May Day Coalition's plans from Powell's Books. ${ }^{13}$

The May Day Coalition, a loosely organized action committee of progressive and radical groups created to conduct the celebration, symbolized the collaboration between workers' rights advocates and environmentalists, which coalesced during the antiglobalization movement's surge in the Pacific Northwest. Ten days of events and preparations beginning on Earth Day preceded the celebration of “International Worker's Day, Beltane, Spring, and resistance to corporation exploitation and control."14 The

\footnotetext{
${ }^{10}$ ILWU Local 5, "Message Notes for May Day,” ILWU Library, ILWU Local 5 Document Archive, May $1,2000$.

${ }^{11}$ Olney, Local 5 Oral History Project, 18-21, 25-26; Portland Police Bureau, "Appendix A: Chronology," May Day Final Report, City of Portland (OR) Archives, May Day Final Report, Record Series 8000-02, June 28, 2000.

${ }^{12}$ Portland Police Bureau, “Appendix A: Chronology,” May Day Final Report, City of Portland (OR) Archives, May Day Final Report, Record Series 8000-02, June 28, 2000.

${ }^{13}$ Portland Police Bureau, “Appendix A: Chronology,” May Day Final Report, City of Portland (OR) Archives, May Day Final Report, Record Series 8000-02, June 28, 2000.

14 “Countdown to Mayday Festival," City of Portland (OR) Archives, May Day, A2005-004, 2000.
} 
coalition intentionally embraced the holiday's ecological and anarchist traditions by holding a picnic in the South Park Blocks complete with a maypole and an unpermitted parade through downtown. ${ }^{15}$ Along the parade route, speakers from four local social justice organizations spoke at City Hall, the World Trade Center, the U.S. Forest Service, and Powell's Books to raise awareness for regional working-class and environmental campaigns. ${ }^{16}$ While the planners acquired a permit for the picnic set to begin after the parade stop at Powell's, their decision to forego a permit for the march disrupted police preparations and responses since the May Day Coalition did not believe that "the rights to speech and assembly should be subject to police approval or regulation."17

The Coalition decided on a climatic show of solidarity for Local 5 by ending the May Day parade at the union's rally in front of Powell's at 5:15 p.m. The day began with a contingent rally at 11:00 a.m. in Northeast Portland's Dawson Park for a "Reclaim the Streets/Pirate Parade" before departing on a march, complete with a papier-mâché pirate ship float, that progressed eastward as far as NE Fremont Street and NE 15th Avenue before turning southwest and crossing the Broadway Bridge on its way to downtown. By the time the crowd of over one hundred protesters reached its rally point in the South Park Blocks three hours later, the police had arrested seven protesters. At the outset and

\footnotetext{
15 "Statement by Ezra Gorman of the May Day Coalition," City of Portland (OR) Archives, Police-May Day 2000, A2008-012, June 27, 2000. "When the May Day Coalition first gathered to plan the May 1st, 2000 celebration we talked about all of the different ways we wanted to create a holiday that would include a wide range of people and bring back to life the long history of May Day as a time to celebrate working people and the start of Spring."

${ }^{16}$ Joining ILWU Local 5 on May Day were speakers from the Community Alliance of Tenants, who spoke about affordable housing at City Hall; organizers from Pineros y Campesinos Unidos del Noroeste (PCUN), who spoke against Senator Gordon Smith's guestworker bill in front of his offices at the World Trade Center; and activists from Cascadia Forest Alliance, who spoke against old growth removal in the Eagle Creek forest.

17 "The Portland Police Attack on Citizen Rights and Political Dissent," City of Portland (OR) Archives, Police-May Day 2000, A2008-012, June 27, 2000, 19.
} 
in the weeks leading up to the event, the Portland police broadly characterized the May Day participants as out of town troublemakers and anarchists because the demonstrators "dressed in black with facemasks like anarchists often do. ${ }^{18}$ At the Park Blocks, the crowd of demonstrators grew to 350 and at 3:00 p.m. commenced its parade loop through downtown.

Chief Kroeker's approach to the demonstration, which he justified as necessary to protect the community from anarchist mayhem, matched the response taken by the Seattle police at the WTO protest and would became characteristic of police response to street protest in years to come. The Oregonian and City Commissioner Erik Sten estimated that Kroeker had one officer for every two May Day marchers. ${ }^{19}$ The clashes that erupted between the two sides prevented the parade from reaching Powell's or its picnic destination. In response to a chipped window at the Nike Store and demonstrators' resistance to commands to leave the streets, the police responded by pushing back with its Mounted Patrol Unit and recently acquired All Terrain Vehicles (ATVs). Video footage captured by police and citizen journalists recorded several demonstrators caught under hoof or wheel as police repeatedly charged into the parade crowd. ${ }^{20}$ As marchers attempted to prevent the arrest of demonstrators, the Portland police canceled the picnic's permit, declared an emergency to disperse the crowd, and detained those who disobeyed. By 4:30pm, the police had surrounded the demonstrators and trapped the crowd against

\footnotetext{
18 Portland Police Bureau, “Appendix A: Chronology,” May Day Final Report, City of Portland (OR) Archives, May Day Final Report, Record Series 8000-02, June 28, 2000.

19 Robin Franzen, "Downtown Protest Turns Ugly," Oregonian, May 2, 2000, A01.; Robin Franzen, "No Clashes Mar Union March, Rally,” Oregonian, May 5, 2000, A01.

${ }^{20}$ A Year in the Streets, produced by the Cascadia Media Collective, (2001), accessed October 5, 2017, https://www.youtube.com/watch?v=QVxXQGEbuC0.
} 
the river wall in Waterfront Park. As demonstrators attempted to comply with contradictory police orders to disperse in two different directions, the police thrusted their batons into dozens of protesters, fired eight bean bag rounds at demonstrators in three separate incidents, and made multiple arrests for those who failed to comply with the confusing police directives. "Cops were not telling people where to go, just shouting 'go,"” reported Willamette Week's on-site reporter who witnessed "10 people standing on the sidewalk, confused about where to go only to be arrested and placed in zip-tie handcuffs." ${ }^{21}$ In the chaos and confusion that interrupted the parade, those able to evade the police's kettle regrouped in front of Powell's Books.

Local 5's May Day rally dramatized the power of the social movement around workers' rights at Powell's Books. The rally began when booksellers walked out on the union's largest ULP strike to date at the Beaverton location and the City of Books, where picketing began at the store's entrance at noon in preparation for the 5:15 p.m. rally. ${ }^{22}$ In response, management directed customers to leave in preparation for a store lock down and pre-arranged request for police presence. Through the large glass windows at the store's entrance, picketing booksellers watched police officers take the seats typically occupied by cashiers at the registers, supposedly guarding the store from looters. ${ }^{23}$ Booksellers, including John McMahon, considered the request for police in response to employees and customers exercising their First Amendment rights a bit ironic for a free

\footnotetext{
${ }^{21}$ Philip Dawdy, "Panic in Portland," Willamette Week, May 3, 2000, 16.

${ }^{22}$ Marcy Rein, "Powell's Workers Stage Largest Unfair Labor Practice Strike to Date," Press Release, ILWU Library, ILWU Local 5 Document Archive, May 1, 2000.

23 “Jim Cowing on Local 5," YouTube video, 32.38, posted by “ilwulocal5," October 31, 2012, https://youtu.be/6dLVWXy7Ee0.
} 
speech advocate like Michael Powell. ${ }^{24}$ Undeterred, a half dozen demonstrators, including Margaret Butler of Jobs with Justice, ensured that they were locked inside where they sat down for a picnic in the Green Room and sang "Solidarity Forever" until the police escorted the group out of the store..$^{25}$

Initially, police presence outside the store was minimal, but by 4:00 p.m. riot police soon surrounded the store, holding back May Day marchers who regrouped at the Powell's rally to escape the police violence at Waterfront Park. "It was scary as hell," expressed Michael Powell to a reporter from the Los Angeles Times, particularly the " 25 people wearing gas masks, hard hats, and all dressed in black and walking toward my store. ${ }^{26}$ Picketing booksellers interpreted the scene differently, believing that the police intended to again disperse the May Day march refugees. Accordingly, Local 5 members called out to them to join their picket. ${ }^{27}$ "It was one of the heaviest things that I've seen for year, I would say since the 60 s, in terms of just police presence," stated longtime activist and ILWU staffer Marcy Rein, "This was really menacing." 28

Meanwhile, a Local 5 delegation and nearly three hundred ILWU delegates were en route to Powell's from the Hilton Hotel where the first day of their convention had just ended. Along the way, the longshore union rejected a request by Lt. Crebs to cancel its

\footnotetext{
${ }^{24}$ Rein, "Powell's Workers Stage Largest Unfair Labor Practice Strike to Date."

25 "Margaret Butler on the Founding of ILWU Local 5." YouTube video, 18:02, posted by "ilwulocalfive," October 24, 2012, https://youtu.be/4jeWAXojrug; Winzig, ILWU Oral History Collection, Tape 1, 17-20; Gail Kinsey Hill, "Protesters Converge on Powell's," Oregonian, May 2, 2000, B01.

${ }^{26}$ Kim Murphy, "It's the Best, Worst of Times at Powell's City of Books," Los Angeles Times, May 7 , 2000, http://articles.latimes.com/2000/may/07/news/mn-27468.

${ }^{27}$ Marcy Rein, "Powell's Workers Meet the ILWU--And Portland Rocks," The Dispatcher, May 2000, 4.

${ }^{28}$ Rein, Local 5 Oral History Project, 9.
} 
march and rally. ${ }^{29}$ When Carole Reichstein and Mary Winzig arrived at the intersection, they found the store surrounded by riot gear clad officers. ${ }^{30}$ "I could see my coworkers. I could see the people I'd worked with in the community being pushed up against with billy clubs, with shields, horses," recalled Winzig, "I mean, it was like a war zone."31 As Brian McWilliams stepped forward to lead the ILWU contingent across West Burnside Street to join the picket, an officer swung and narrowly missed striking the union president with a club. Undeterred, Rein recalled that McWilliams' actions kept the police in check and as the union delegates pressed forward the police "melted back" in response. $^{32}$

There, in the middle of the street under a puppet of Michael Powell and his store's iconic sign, Local 5 booksellers met their fellow ILWU members for the first time. ${ }^{33}$ The walk-out, combined with the hundreds of demonstrators rallying outside the store, compelled management to close early for the day, for only the second time its twentynine year history. ${ }^{34}$ As managers stood watching the picket through the glass window, Jim Cowing recalled a witty bookseller appropriating and scribbling the word "SHELVE" (a typical management directive given to idle employees) on the back of a picket sign for a line of grinning supervisors to take notice. ${ }^{35}$ For the booksellers, longshore workers, and community allies that participated in the action, the importance of

\footnotetext{
${ }^{29}$ Philip Dawdy, "Panic in Portland," Willamette Week, May 3, 2000, 16: "When this union decides to march in the streets," ILWU communications director Steve Stallone told a local reporter, "we don't ask for a fuckin' parade permit."

${ }^{30}$ Carole Reichstein, "From Picket Signs to Dotted Lines," Bridges, ILWU Library, ILWU Local 5

Document Archive, August/September, 2002, 3.

${ }^{31}$ Winzig, ILWU Oral History Collection, Tape 3-4, 17-21.

${ }^{32}$ Rein, Local 5 Oral History Project, 10.

${ }^{33}$ Rein, Local 5 Oral History Project, 10-12.

${ }^{34}$ The first and only other day Powell's Books closed was for Walter Powell's funeral.

35 "Jim Cowing on Local 5," YouTube video, https://youtu.be/6dLVWXy7Ee0?t=15m55s.
} 
this moment proved unavoidable. "It was amazing," recalled Winzig, "It just made me so proud to be there with all those brothers and sisters just taking over the streets. I was like, 'Wow! This is what it's all about.' This is how revolutions start, this is what life is about, this is the workers together changing things." ${ }^{" 36}$

The energy Local 5 created during the May Day strike continued the next day and on throughout the duration of the ILWU Convention, contributing to what booksellers described as a power shift at the bargaining table during the following months. The next morning, over fifty Powell's employees attended the ILWU convention to a warm welcome by fellow union members. After Winzig delivered a rousing speech, delegates gave the booksellers a standing ovation and a couple thousand dollars in cash collected from attendees for their strike fund. ${ }^{37}$ The ULP strike continued for a second day, with booksellers participating in the strike and disrupting operations at several of the company's work sites, including the Hawthorne stores, Hoyt warehouse, and Internet computer support center. ${ }^{38}$

The union kept up pressure on Michael Powell with a "Hands Around Powell's" action on May 4 that again began with a march from the convention hotel to Powell's Books. Booksellers Sarah Race and Ciara McEwan addressed the crowd, raising concerns of excessive force by local police on May Day. ${ }^{39}$ Oregon AFL-CIO President Tim Nesbitt and Teamsters Local 206 President Tom Leedham joined McWilliams in addressing the

\footnotetext{
${ }^{36}$ Winzig, ILWU Oral History Collection, Tape 3-4, 20.

37 “Jim Cowing on Local 5," YouTube video, https://youtu.be/6dLVWXy7Ee0?t=11m15s.

${ }^{38}$ Marcy Rein and Michael Cannarella, "Powell's Workers Strike Today,"” Media Advisory, ILWU Library, ILWU Local 5 Document Archive, May 6, 2000; Robin Franzen, "No Problems between Police, Union Marchers at Rally" Oregonian, May 5, 2000, A09; Rein, "Powell's Workers Meet the ILWU," 4. 39 "Jim Cowing on Local 5," YouTube video, https://youtu.be/6dLVWXy7Ee0; Rein, "Powell's Workers Meet the ILWU," 4.
} 
rally, which included community members and a hundred booksellers, some dressed in black with dyed hair and piercings, standing arm-in-arm with ILWU convention delegates surrounding the store. ${ }^{40}$ Rein recalled the important role this action and the May Day demonstration played in breaking down previously held prejudices between the two groups of workers. ${ }^{41}$

Jeff Hensley recalled that in his mind the ILWU convention and strike not only energized Local 5 but compelled motion at the bargaining table from the Powell's side. ${ }^{42}$ The local printed t-shirts with the slogan "We Shut Them Down" to commemorate the May Day strike and bolster confidence in future actions. ${ }^{43}$ Before the end of the month, Local 5 conducted two more ULP strikes, on May 6 and on the Memorial Day holiday. ${ }^{44}$ Winzig remembered that the events of May Day and the Convention made her "believe what a union can do" as well as illustrate the reciprocal relationship between the union and Portland's social justice community. ${ }^{45}$ In the wake of May Day, Police Chief Kroeker and Mayor Vera Katz received considerable blame for their role in the police violence

\footnotetext{
${ }^{40}$ Olney, Local 5 Oral History Project, June 3, 2002, 18-21; Winzig, ILWU Oral History Collection, Tape 3-4, 20-21; "Jim Cowing on Local 5," YouTube video, https://youtu.be/6dLVWXy7Ee0?t=17m51s; Marcy Rein, "ILWU Takes its Convention to Powell's Books," Media Advisory, ILWU Library, ILWU Local 5 Document Archive, May 3, 2000.

${ }^{41}$ Rein, Local 5 Oral History Project, 12;

42 Jeff Hensley, Local 5 Oral History Project, 10-13.

${ }^{43}$ Mary Zartman, interviewed by Edward Beechert, Local 5 Oral History Project, ILWU Library, April 12, $2002,11$.

${ }^{44}$ Winzig, ILWU Oral History Collection, Tape 3-4, 20-21; Mary Winzig, interviewed by Edward Beechert, Local 5 Oral History Project, ILWU Library, August 20, 2001, 7-10; Michael Cannarella, "Powell's Workers and Friends Splash into Summer Shopping Season,"” Media Advisory, ILWU Library, ILWU Local 5 Document Archive, May 26, 2000; ILWU Local 5, "Message Notes for Memorial Day Weekend," ILWU Library, ILWU Local 5 Document Archive, May 2000. Prior to the May 6 strike, the union alleged that Powell's management took surveillance video footage of employees participating in the Hands Around Powell's event and the St. Patrick Day Strike on March 17. The local also complained that management wrote down the names of those who participated on the May 4 strike. The May 31 ULP strike was over the union's allegation that a worker's pre-approved vacation request was rescinded as a result of the employee's outspoken union support.

${ }^{45}$ Winzig, ILWU Oral History Collection, Tape 3-4, 17-20; Winzig, Local 5 Oral History Project, 7-10.
} 
against the parade from citizens, community groups, and Local 5. At a City Council meeting in June, bookseller Matt Baker presented a statement from the union condemning the police department's use of excessive force and its violations of civil liberties that included videotaping the booksellers' picket lines. In his own statement, Baker called out police efforts to divide Local 5 and its rally from the May Day Coalition's activities earlier in the day: "Even though our tactics and strategies may differ," he stated, "we fully support the Portland activist community in standing up against injustice, and likewise, we know the Portland activist community supports the ILWU local 5 in our struggle against injustice. ${ }^{26}$ In years to come, May Day became an annual protest and celebratory holiday for Local 5 and the Portland activist community with the number of participants increasing into the thousands.

\section{Workers' Rights Board}

Through a collaboration with Jobs with Justice, Local 5 escalated its campaign to apply social pressure upon Michael Powell. In April, Jobs with Justice began planning its signature Workers' Rights Board (WRB) hearing for Powell's employees. The WRB presented itself as a community alternative to the NLRB, which union activists criticized as slow and secretive. Conversely, Jobs with Justice designed the WRB as an open forum to amplify the testimonials of workers to both community leaders and the general public.

The new WRB occurred in June 2000 two months after both sides agreed to federal mediation by experienced labor mediator Jim Bailey in closed door bargaining

\footnotetext{
46 "Statement by Matt Baker, member of International Longshore and Warehouse Union (ILWU) Local 5," City of Portland (OR) Archives, Police-May Day 2000, A2008-012, June 27, 2000; Maxine Bernstein, "Critics Decry May Day Review Portland's Police Chief and Marchers Comment at a Hearing on the Protest," Oregonian, June 29, 2000, D01.
} 
sessions. ${ }^{47}$ The process began when Michael Powell received a letter from the WRB in mid-May inviting him to its public hearing on his bookstore's contract dispute. The letter stated that Powell's Books was a local institution and what happened there "either shines a light or casts a shadow over the entire community." 48 It listed the names of the fiftyseven community leaders that comprised the membership of the newly formed board, including elected officials, professors, and clergy. The board included City Councilor Erik Sten and two Multnomah County Commissioners, plus leading Oregon Democrats State Senators Avel Gordly and Frank Shields, sitting State Representative Diane Rosenbaum and former Representative Margaret Carter. Moreover, the board members' progressive character was reflected in their organizational affiliations, including the Oregon Human Rights Coalition, the Virginia Garcia Clinic, 1000 Friends of Oregon, and the Oregon State Public Interest Research Group (OSPIRG).

The organized and public statement by the community leaders associated with the WRB signified a shift in the social pressure campaign directed at Michael Powell that had previously involved prominent citizens contacting the bookstore owner individually and privately. Michael Cannarella speculated that the names on the WRB letterhead may have convinced Powell to settle the contract because the union "finally got to a couple of people he cared about $[\ldots]$," the politicians and community leaders who Powell saw as his peers. ${ }^{49}$ Powell declined the invite in a written response to the WRB signatories, but

\footnotetext{
${ }^{47}$ When Local 5 and Powell's Books invited James R. Bailey to mediate the final contract, Bailey served as the Commissioner of the Federal Mediation and Conciliation Service and had previously acted as both a mediator for the State of Oregon and a labor relations specialist for the Oregon Nurses Association and the Service Employees International Union.

${ }^{48}$ Portland Workers' Rights Board to Michael Powell, 15 May 2000, letter, ILWU Library, ILWU Local 5 Document Archive.

${ }^{49}$ Michael Cannarella, interviewed by Edward Beechert, Local 5 Oral History Project, ILWU Library September 4, 2002, 11-14.
} 
expressed some optimism in the federal mediator's ability to negotiate a mutually agreeable settlement over the union's demand for a security clause, which Powell argued would force him to "fire employees whose personal convictions do not support a labor organization. ${ }^{{ }^{50}}$ Winzig recalled the surprise and anger from Rabbi Ariyeh Hirschfield when he heard the testimony of booksellers, including Ryan Van Winkle's testimony about how even during a good month his hourly wage did not leave him with enough money to replace his only pair of shoes and left him needing to choose between a doctor's or a dentist's appointment. ${ }^{51}$ Nine employees provided testimony, including Doug Chase, who was a vocal opponent of the union during the election campaign. Chase testified about how witnessing Larry Amburgey's behavior at bargaining sessions swayed him to support the union, "It was difficult to watch the attorney insult my co-workers." 52

The WRB summarized its findings and recommendations in a letter to Michael Powell, concluding that the company's behavior during negotiations violated four "fundamental community values:" democratic rights, right to a living wage, right to healthcare, and freedom from discrimination. The WRB recommended that the bookstore owner agree to a union shop "as an affirmation of the democratic process and the principle of majority rule and equal taxation for services rendered." ${ }^{53}$ Powell chose not to attend the WRB and instead called Multnomah County Commissioner and board member

\footnotetext{
${ }^{50}$ Michael Powell to Portland Workers' Rights Board, 25 May 2000, letter, ILWU Library, ILWU Local 5 Document Archive.

${ }^{51}$ Winzig, ILWU Oral History Collection, Tape 3-4, 21-24; Tricia Schultz and Mary Winzig, "Community Board Calls for Open Books in Powell's Dispute," Press Release, ILWU Library, ILWU Local 5 Document Archive, June 13, 2000.

${ }^{52}$ Don McIntosh, "Portland Workers' Rights Board Hears Powell's Bookstore Case," Northwest Labor Press, July 7, 2000, https://nwlaborpress.org/2000/7-7-00WRB.html.

${ }^{53}$ Portland Workers' Rights Board to Michael Powell, 22 June 2000, letter, ILWU Library, ILWU Local 5 Document Archive.
} 
Diane Linn to set up a private meeting that occurred in early July. Previously, Powell refused to meet with any employees or community leaders about the campaign and, for the first time, Powell admitted to the community leaders, including Rosenbaum who chaired the June hearing, that he understood now that he would have to sign a contract that included some version of a union security clause that required employees to become members of the local. ${ }^{54}$ Furthermore, with nearly 75 percent of the workforce participating in ULP strikes, management's hope for a decertification campaign to materialize and oust the union proved unrealistic by June. Still, after so much resistance, Powell's reversal on bargaining surprised some booksellers, including John McMahon. ${ }^{55}$

\section{Forging a Contract}

Michael Powell and the management team's new motivation to bargain increased the pressure on the Powell's negotiating committee and the booksellers to decide on priorities for a first contract. While some booksellers welcomed the entry of Jim Bailey as a federal mediator who could bring the two sides closer together, other union activists observed that the dynamic created by mediation "lowered the temperature" of the exchange and freed the company from the public scrutiny or public shaming that seemed to have proved so effective. Additionally, the mediation stage heightened the role of ILWU Organizing Director Peter Olney and decreased the role of the workers on the committee, as Olney became the lead negotiator for the union against Amburgey with Jim Bailey mediating between the two leaders privately. ${ }^{56}$ The tension within the local focused on the question of how much could the union achieve in its inaugural contract.

\footnotetext{
54 "Margaret Butler on the Founding of ILWU Local 5," https://youtu.be/4jeWAXojrug.

${ }^{55}$ John McMahon, interviewed by Edward Beechert, Local 5 Oral History Project, ILWU Library, 13-18.

${ }^{56}$ Olney, Local 5 Oral History Project, 25-26; Hensley, Local 5 Oral History Project, 13-17.
} 
Olney expressed frustration with some Local 5 members' aspirations for a first contract, recalling that some of the union-activists had expectations that were unattainable without significantly more union power and leverage.$^{57}$ Olney clarified his point by detailing the difference between might and right; from the outset of the campaign, he sought to impart upon the organizers that regardless of whether a demand was just, in order to win the union needed to hold "the power to force the employer to accept [the demands]." ${ }^{58}$ To that point, Local 5 began collecting boycott pledges in April from customers to take place on Labor Day if management continued to resist the union's contract terms. ${ }^{59}$

After fifty-three bargaining session over the course of ten months and the assistance of a federal mediator, both bargaining teams finally agreed upon a three-year contract that included significant improvements for Powell's booksellers. The breakthrough occurred on August 1, 2000, nearly a year after negotiations began, when management and Local 5 announced a tentative agreement for a collective bargaining agreement at the end of a five-hour meeting. Anxious to put an end to the conflict, Michael Powell looked forward to turning the company's attention "to maintaining Powell's position as the best independent bookstore in the land." ${ }^{60}$ The twelve-member union bargaining team unanimously recommended membership ratification of the contract. "We feel it represents a positive step for us, for Powell's Books, for retail

\footnotetext{
${ }^{57}$ Olney, Local 5 Oral History Project, June 3, 2002, 22-24, 25-26, 13-16.

${ }^{58}$ Olney, Local 5 Oral History Project, June 3, 2002, 14.

${ }^{59}$ Winzig, Local 5 Oral History Project, 10-12; Olney, Local 5 Oral History Project, 25; Michael Cannarella, "Forbes Touts Powell's Profitability as Contract Talks Stall," Press Release, ILWU Library, ILWU Local 5 Document Archive, April 20, 2000; ILWU Local 5, "Local 5/Powell's Talks Show Possible Progress--Help Push for More!” leaflet, ILWU Library, ILWU Local 5 Document Archive, April 12, 2000. ${ }^{60}$ Steffen Silvis, "Final Chapter in Powell's Epic Contract Odyssey," Willamette Week, August 2, 2000.
} 
workers in general and for the Portland community," it stated. ${ }^{61}$ In sharp contrast to the narrow union election sixteen month earlier, employees overwhelmingly voted to approve the first contract by 293 to 37 with an 80 percent turnout. ${ }^{62}$ Bookseller Meredith Schafer explained the dramatic reversal in numbers compared to the union election as the product of a cultural change that took place in the workplace, initiated by the union election campaign but ubiquitous during the contract campaign as workers lost confidence in management after seeing its antagonism at the bargaining table. ${ }^{63}$ Schafer added that employees no longer ascribed to the culture management propagated of trusting its decisions. ${ }^{64}$ In bright colored chalk, union members announced the final vote tally on the sidewalk outside the Burnside store and set their aim on growing their local. "Welcome to Powell's. Ask us about organizing your workplace," their message proclaimed. ${ }^{65}$

The union claimed victory with the contract, pointing to both economic gains and new policies that protected employees from disciplinary mistreatment. The union solidified 18 percent wage increases for employees over three years and immediate full vesting in the company's $401 \mathrm{~K}$ retirement program, economic accomplishments that far outpaced any of the gains made by the UFCW at its unionized bookstores. Moreover,

${ }^{61}$ ILWU Local 5, "Dear Co-workers," Bridges to Bargaining, ILWU Library, ILWU Local 5 Document Archive, August 1, 2000.

${ }^{62}$ Kristen Russ, "No Decisions About Us Without Us: A History of a Bookstore Union," No Decisions About Us Without Us: History of Local 5 - Powell's Books, ILWU Local 5, accessed December 28, 2016, http://ilwulocal5.com/?page id=46; "Powell's workers ratify first contract, Northwest Labor Press, August 18, 2000, https://nwlaborpress.org/2000/8-18-00ILWU.html; Gail Kinsey Hill, "Powell's Workers OK Contract, Oregonian, August 11, 2000, D01.

${ }^{63}$ Meredith Schafer, interviewed by Edward Beechert Local 5 Oral History Project, ILWU Library, August 21, 2001, 15-18.

${ }^{64}$ Schafer, Local 5 Oral History Project, 15-18.

${ }^{65}$ Marcy Rein, "Local 5 Celebrates Huge Contract Win," The Dispatcher, July-August 2000, 3, accessed September 19, 2017, http://archive.ilwu.org/wp-content/uploads/2015/04/20000708.pdf. 
Local 5 resurrected the Compensation Committee that management disbanded prior to the union drive. It also won a grievance procedure to settle disputes during the length of the contract and eliminated at-will termination with the inclusion of a progressive disciplinary procedure and just cause policy for discharge. Furthermore, the union fought off efforts by Powell's to increase the employee cost for health care and preserved the popular childcare benefit. ${ }^{66}$ The local championed the contract's Partner Program arrangement with Powell's, through which the union would retain and distribute to members 10 percent of sales that originated from Local 5 directing visitors to Powell's online store. ${ }^{67}$ While Michael Powell conceded on the union security clause, the union compromised by agreeing to a "conscientious objections" clause, that allowed a limited number of current employees to refrain from joining the union or paying the fair share of cost bargaining a contract so long as the booksellers contributed an equal amount to charity. ${ }^{68}$

Although Michael Powell preferred not to deal with the union and was forced to give up some of his employer power by signing a contract with his workers, the agreement included several of his bargaining team's initial goals and secured management's authority over all aspects of the business not addressed in the contract.

\footnotetext{
${ }^{66}$ Winzig, ILWU Oral History Collection, Tape 3-4, 24.

${ }^{67}$ Hensley, Local 5 Oral History Project, 13-17; Meredith Schafer, "Web Profit Sharing with Local 5 Halfway to $\$ 10,000$ Goal!" Bridges, March 2002, 1. In its first full year, Local 5's Partner Program directed $\$ 36,857$ in total sales to Powell's website, 0.3 percent of Powell's Books total sales the previous year.

${ }^{68}$ Cowing, Local 5 Oral History Project, 16-17; Article 3.3 Exception for Other Conscientious Objections. The Union and Employer will, in good faith, entertain a very limited number of conscientious objections to financial support of the Union provided that such requests are made known to the Company no later than September 15, 2000. Such requests may be made only by employees hired prior to the date of execution of this Agreement. An employee accepted in this category will be required to pay an amount of money equivalent to regular dues to a qualified charitable organization selected by the employee. Payments are to be made on a regular monthly basis or in advance, and proof of payment will be sent by the employee to the Union within ten (10) calendar days of each payment.
} 
Local 5 lost the fight for a successor clause in the contract that would have secured the union's presence if Powell sold the company. The local also gave up its paid lunch breaks in return for a onetime 6.67 percent pay increase. ${ }^{69}$ Furthermore, Powell's Books won a broadly written management's rights clause over how to operate the business as well as a no strike clause that prevented workers from striking during the length of the contract. ${ }^{70}$

Local 5 found involving members in the day-to-day needs of the union more difficult after signing the contract, but the union-activists who carried the weight of the campaign continued to provide critical leadership in the first months. ${ }^{71}$ The two-year union struggle left many booksellers exhausted and fatigued, helping to explain the low meeting attendance and voter turnout during the union's first elections. The first task the union took on was the drafting of the local's constitution, which took nine meetings totally over twenty hours. ${ }^{72}$ In comparison to ULP strikes and contentious contract negotiations, the task of the nineteen member constitution committee proved far less exciting and saw only thirty-one members of the bargaining unit cast ballots when the committee presented its proposal for approval in early October. ${ }^{73}$ In December, the union newsletter included discussion about the low member participation and the names of six newly elected officers, who ran unopposed.

${ }^{69}$ ILWU Local 5, "Article 13.7 Education Benefit," Collective Bargaining Agreement between Powell's Books, Inc. and International Longshore and Warehouse, Local 5, August 14, 2000, 35, http://www.powellsunion.com:80/Contract.txt, Internet Archive, accessed September 20, 2017, https://web.archive.org/web/20020207230844/http://www.powellsunion.com:80/Contract.txt.

${ }^{70}$ ILWU Local 5, "Article 5.1 Management Rights," Collective Bargaining Agreement between Powell's Books, Inc. and International Longshore and Warehouse, Local 5, August 14, 2000, 6, http://www.powellsunion.com:80/Contract.txt, Internet Archive, accessed September 20, 2017, https://web.archive.org/web/20020207230844/http://www.powellsunion.com:80/Contract.txt.

${ }^{71}$ Hensley, Local 5 Oral History Project, 13-17.

${ }^{72}$ ILWU Local 5, "Local 5 Update," Bridges, ILWU Library, ILWU Local 5 Document Archive, September 15, 2000.

${ }^{73}$ ILWU Local 5, "Local 5 Update," Bridges, ILWU Library, ILWU Local 5 Document Archive, September 15, 2000. 
The new officers discovered that they needed to simultaneously learn how to operate the affairs of a union local, continue organizing booksellers, and represent members against management's efforts to reinterpret the contract. As the ILWU international staff turned their attention to other issues, Local 5's new leaders needed to learn as much as they could about running a union local. ${ }^{74}$ Fortunately for them, the local labor movement continued to help with LERC providing additional training to prepare members for enforcing their contract, conducting administrative affairs, and handling arbitration and safety concerns. ${ }^{75}$ Mary Winzig, who received the sole nomination for the local's first president, stated that she hoped she could get booksellers to become active members in their union and participate in the local activist community. ${ }^{76}$ Expectedly, organizers and bargaining team members filled the other union officer positions. Jim Cowing, known as the "numbers guy" on the union's bargaining team, became the union's first Secretary/Treasurer, and veteran Powell's employee Jeff Hensley became the union's Chief Steward. Carol Edwards defeated John McMahon to become the union's first Vice President in the only position that went to a ballot election. Hoyt warehouse worker Ryan Takas became the Union Representative and the only paid staff member of the union, responsible for internal and external organizing at a $\$ 2,250$ monthly salary.

\footnotetext{
${ }^{74}$ Hensley, Local 5 Oral History Project, 13-17.

${ }^{75}$ Winzig, Local 5 Oral History Project, 12-15; Takas, Local 5 Oral History Project, 3-5; Zartman, Local 5 Oral History Project, 11-16.

${ }^{76}$ Brandon Cotter, "Forget George Dubya, Meet Our Local's First President, Mary Winzig," Bridges, ILWU Library, ILWU Local 5 Document Archive, March/April 2001, 3; Olney, Local 5 Oral History Project, June 3, 2002, 9-11; Winzig, Local 5 Oral History Project, 12-15.
} 
When a series of management provocations and a shift in the nation's political climate occurred in 2001, many employees again turned inward towards the union. Early disagreements between the union and management regarding the interpretation of the contract provided the context to motivate members into action. Certain workers perceived the conservative shift in national politics, in particular the incoming administration of President George W. Bush, as a fundamental threat to the labor movement. Such realizations compelled Cowing, McMahon, and others to stay involved in Local 5's solidarity work. ${ }^{77}$ Yet, provocation or politics aside, many booksellers indicated that the union provided opportunities for them to share talents and develop new skills. For example, Mary Zartman described the enjoyment she found in writing a monthly column in the union's newsletter. ${ }^{78}$ Nevertheless, Cal Hudson clarified that complacency proved a major obstacle for Local 5, more so than any anti-unionism from managers or fellow employees. "It's easier to get people to fight a battle than it is get them to contribute to the day-to-day operations of the local," noted Hudson. ${ }^{79}$ This dynamic was particularly true for workers new to the company, who did not experience the union organizing or contract campaigns.

Early contract interpretation battles between booksellers and Powell's management involved the company's educational benefit, the contract's automatic track promotions clause, and management's changes to its timekeeping policy. Despite hopes for a new era of goodwill, there was little space for such sentiments during the first

\footnotetext{
${ }^{77}$ McMahon, Local 5 Oral History Project, 13-18

78 Zartman, Local 5 Oral History Project, 11-16.

${ }^{79}$ Cal Hudson, interviewed by Edward Beechert, Local 5 Oral History Project, ILWU Library, May 20, 2001, 9-11.
} 
months of the agreement as Local 5 and Powell's management clashed over these contract interpretations. Powell's Books began offering an educational stipend prior to the union campaign but Local 5 secured and increased the benefit within the first contract, providing thirty employees each quarter with a $\$ 300$ maximum stipend for qualifying educational classes ${ }^{80}$ When management changed its past practice of covering multiple classes as long as the total was under the maximum stipend to only covering the cost of one class, booksellers cried foul and initiated a resistance campaign on the shop floor. True to past form, booksellers began wearing stickers with the slogans "Unskooled" and "'Class' War" that conveyed their united opposition to management's policies. ${ }^{81}$ The union campaign compelled management to agree with the original intent of the agreement, securing the full monetary benefit, without needing to go to arbitration. Additionally, Local 5 succeeded in negotiating a settlement with the company on the automatic track promotion clause, which Meredith Schafer attributed to both bookseller and Union Representative Ryan Takas' leadership on the issue and the union's democratic decision-making process. ${ }^{82}$

Local 5 viewed store management's changes to the timekeeping policy as out of line with its past practices, but consistent with the company's recent shift to a more corporate approach to managing employees. Management's unilateral timekeeping changes proved the most contentious issue with the booksellers in the post-contract

\footnotetext{
${ }^{80}$ ILWU Local 5, “Article 13.7 Education Benefit," Collective Bargaining Agreement between Powell's Books, Inc. and International Longshore and Warehouse, Local 5, August 14, 2000, 35, http://www.powellsunion.com:80/Contract.txt, Internet Archive, accessed September 20, 2017, https://web.archive.org/web/20020207230844/http://www.powellsunion.com:80/Contract.txt. ${ }^{81}$ ILWU Local 5, “'Class' War \& Unskooled” sticker, ILWU Library, ILWU Local 5 Document Archive, 2001; Hudson, Local 5 Oral History Project, 9-11.

${ }^{82}$ Schafer, Local 5 Oral History Project, 20-23, 12-15.
} 
period and had an impact upon employees that continued for years. The transition from a lenient to a strict observation of timekeeping policies preceded the union campaign but was formalized by February 2001 into a new Timekeeping Policy. Winzig described the timekeeping policy as the union's Achilles' heel, an issue that both challenged the booksellers' previous control over their workdays and undercut their just cause contract clause. $^{83}$

The union believed that management, who lost its right to terminate employees atwill with the union contract, sought to reclaim its control over firing employees by a strict enforcement of the timekeeping policy and filed a Class Grievance. Booksellers, who found their clock-in times and the length of their lunch breaks increasingly scrutinized, saw management's pivot on timekeeping as retribution for the union and a means to terminate employees using the rules of the contract. Schafer was quick to observe that the company began using time keeping as a disciplinary tool "when they need to get rid of you." ${ }^{84}$ Powell's booksellers spoke out together on the timekeeping policy by wearing stickers that called attention to the issue and in writing an open letter to Michael Powell, requesting that he meet with employees on the issue. "We are not machines," declared the letter signed by over 140 workers. ${ }^{85}$ The booksellers critiqued the company's rigid application of the timekeeping policy, which the employees argued existed "to intimidate workers and make them forget about their rights on the job." ${ }^{86}$ In February 2002,

\footnotetext{
${ }^{83}$ Winzig, Local 5 Oral History Project, 13.

${ }^{84}$ Schafer, Local 5 Oral History Project, 15-18.

${ }^{85}$ Employees to Michael Powell, 2001, letter, ILWU Library, ILWU Local 5 Document Archive.

${ }^{86}$ Zartman, Local 5 Oral History Project, 7-11, Winzig, Local 5 Oral History Project, 12-15; Reichstein, Local 5 Oral History Project, 6-9; Employees to Michael Powell, 2001, letter, ILWU Library, ILWU Local 5 Document Archive.
} 
management agreed to negotiate with the union on the contentious topic and as a result a settlement was reached before the issue went to arbitration. In return for the union dropping all grievances and foregoing arbitration, management revised the policy and the disciplinary actions that were taken against members for timekeeping violations in the preceding year. ${ }^{87}$

\section{Organizing the Unorganized}

With the Powell's contract bargained and signed, Local 5 union activists began looking to fulfill their primary non-Powell's related goal: growing the local by organizing the unorganized. Although Local 5 gained two new bargaining units within six months of receiving its union charter, the growth did not come from new organizing campaigns in the Portland metro at its own initiative. Rather, the expansion resulted from the international union organizing workers into Local 5 to avoid placing them in traditional longshore locals. Subsequently, Local 5 came to represent distinctly different occupational groups geographically separated by hundreds of miles and, ultimately, pulled the union away from its goal of spearheading a new union movement in Portland.

At the same time, the Powell's Books campaign inspired the booksellers at Seattle's University Book Store to begin organizing a union with the ILWU. Similar to its counterpart in Portland, University Book Store was its city's largest independent bookstore and a local institution, operating on the University of Washington's campus since 1900. In September 2000, soon after Local 5 approved its first contract, four University Book Store employees drove to Portland to meet with a group Powell's union

\footnotetext{
${ }^{87}$ Ryan Takas, “Timekeeping Class Grievance Settlement: It's About Damn Time," Bridges, ILWU Library, ILWU Local 5 Document Archive, April 2002, 1-2.
} 
activists. The two groups of booksellers discussed organizing and shared their motivations for unionization. "They talked, as we have, about widespread dissatisfaction with pay" and worry about losing benefits, stated University Book Store employee Zachary Marcus. ${ }^{88}$ In December 2000, the Seattle booksellers initiated an organizing campaign modeled on the Powell's experience and delivered a petition signed by thirtyfour booksellers that informed the company of their intent to organize a union with the ILWU. If the bookseller organized like the Powell's workers, store management's written response and warning that "a union would drastically change our culture" echoed the sentiments once expressed by Michael Powell. ${ }^{89}$ In January, Local 5 booksellers visited Seattle to share their experience with the booksellers interested in unionizing. ${ }^{90}$ Although the campaign did not succeed and was not an official Local 5 project, its existence demonstrated the power of Local 5's story to inspire workers to organize.

As the Powell's booksellers were finalizing the details of the tentative agreement, two hundred miles away in Coos Bay workers at the South Coast Hospice voted to join the ILWU. ${ }^{91}$ When the hospice workers joined the ILWU in March of 2000, the longshore union found itself amidst uncertainty regarding where their new fellow unionists fit into the traditional longshore workforce. While the local ILWU membership

\footnotetext{
${ }^{88}$ John Marshall, "Workers Seek Union at University Book Store," Seattle Union Record, December 22, 2000, http://www.unionrecord.com:80/metro/display.php?ID =1461, Internet Archive, accessed September 17, 2017, https://web.archive.org/web/20010406061805/http://www.unionrecord.com:80/metro/display.php?ID $=1461$.

${ }^{89}$ Marshall, "Workers Seek Union at University Book Store," https://web.archive.org/web/20010406061805/http://www.unionrecord.com:80/metro/display.php?ID $=1461$.

${ }^{90}$ University Book Store Union Organizing Committee, "Want to Know More About the Union?" The Yawp, ILWU Library, ILWU Local 5 Document Archive, January 8, 2001.

${ }^{91}$ Rein, Local 5 Oral History Project, 12-15; Brandon Cotter, "Interview with Staci Sandlee, Bargaining Unit Rep from Coos Bay,” Bridges, ILWU Library, ILWU Local 5 Document Archive, March, 2002, 3. The South Coast Hospice workers and their employer sign a first contract on October 18, 2001.
} 
generally supported the international's efforts to grow the union by organizing within new economic sectors, the longshore membership proved reluctant to allow nonlongshore workers into its established locals. The union's tradition of autonomous rankand-file control of locals, dominated by longshore workers, led to the international union deciding to assign the thirty-five-member South Coast Hospice bargaining unit to Local 5 instead of longshore Local 12 in Coos Bay. Without any deliberation with Local 5, international officials informed Powell's union members of this decision and local's new administrative duties for the Coos Bay workers. While from the beginning Local 5 unionactivists articulated a vision of organizing the unorganized, the ILWU's inclusion of the Coos Bay bargaining unit into Local 5 created challenges for the Portland based booksellers that had the opposite reaction. First, the distance to Coos Bay proved exceedingly difficult for a workforce and union officers that relied on bicycling and public transportation, creating an obstacle for officers to stay in contact with the workers. Furthermore, the enthusiastic union activists envisioned Local 5 being more of a local leader in organizing within Portland rather than a regional repository for ILWU organizing campaigns. Second, the inclusion of the South Coast workers into Local 5 occurred as the local's officers adjusted to the new responsibilities enforcing the Powell's contract, creating additional workload for a local trying to establish roots.

In January 2001, Local 5 acquired another bargaining unit over one hundred miles away in Olympia, Washington. Similarly to how Powell's employees selected the ILWU as their union, the food-service workers at Evergreen State College shopped for a union in the fall of 2000 after several months of organizing and ultimately decided on the 
ILWU over the Industrial Workers of the World (IWW) and two other unions. ${ }^{92}$ Initially, the bargaining unit of over forty workers planned to join Olympia's ILWU Local 47, but soon after the election the international union decided to place the workers within Local $5 .{ }^{93}$ Within less than six months after receiving its union charter, therefore, Local 5 expanded to comprise nearly five-hundred members all within their first collective bargaining agreement and spread out between worksites over 350 miles apart. Powell's Books and their union hall one block from the City of Books became the geographical and administrative center for the new local. These challenges prompted the union to approve an amendment to its constitution in December 2001 that restricted Local 5's geographical jurisdiction to Portland, Olympia, and Coos Bay. ${ }^{94}$

The contract agreement reached between Local 5 and Powell's provided the union the security, foundation, and platform to speak out on political causes and integrate itself into the local activist community. Three days after the union signed its first union contract, the Local 5 joined the Cascadia Forest Alliance to host a public forum entitled Labor/Environmental Solidarity and a Sustainable Portland. ${ }^{95}$ The union marched in the streets with fellow unionists in opposition to fast track approval by Congress of the Free

\footnotetext{
${ }^{92}$ Winzig, ILWU Oral History Collection, Tape 1, 19-24; Olywobs Media Collective, "Fine Host," Riff Raff, Olympia General Membership Branch, Industrial Workers of the World, Number 2, accessed September 17, 2017: http://www.azinelibrary.org/approved/riffraff.pdf, Olywobs Media Collective, "Fine Host," Riff Raff, Olympia General Membership Branch, Industrial Workers of the World, Number 3, accessed September 17, 2017: http://azinelibrary.org/approved/riff-raff-3-1.pdf; Although the Evergreen State College food-service workers decided to seek employer recognition with the ILWU, the Olympia branch of the IWW had previously contributed to the workplace organizing efforts and continued to provide assistance as the workers fought for recognition from their employer First Host.

${ }^{93}$ Paul Bigman, “Organizing Victory in Olympia!” Organize Your Workplace, ILWU Local 19, accessed September 17, 2017, https://www.ilwu19.com/organize/olympia.htm.

${ }^{94}$ Ryan Takas, "Constitutional Changes," Bridges, ILWU Library, ILWU Local 5 Document Archive, February 2002, 1.

${ }^{95}$ ILWU Local 5, "Booksellers and Blockaders: Together at Last!” poster, ILWU Library, ILWU Local 5 Document Archive, August 17, 2000.
} 
Trade Area of the Americas (FTAA), a trade agreement similar to the North American Free Trade Agreement (NAFTA) but expanded to include nearly all countries of in the Americas. ${ }^{96}$ In another show of unity with the local labor movement, Local 5 joined several other unions and passed a resolution at its April membership meeting calling upon the city council to reverse its decision to join the Federal Bureau of Investigation's (FBI) Joint Terrorism Task Force. Unions feared that the FBI could use the partnership to suppress organized labor's political activity. ${ }^{97}$ The union, under the leadership of Jim Cowing, joined in international solidarity actions to protest the felony riot charges levied upon a group of Southern longshore workers known as the Charleston Five for picketing a non-union dock company. ${ }^{98}$

The ILWU's expanded organizing program during President McWilliams' term and the creativity of Powell's booksellers intersected during a surge of activity and unity among social justice movements. The gains made by Local 5 booksellers in their first contract with Powell's Books reaffirmed the union-activists' motivations for organizing and positioned the small but ambitious new local with the narrative, experience, and community to continue its organizing and political work throughout Portland. Brian McWilliams officially signed the union charter for Local 5, describing the moment as "one of my proudest moments as President of the ILWU."99

Peter Olney described the Local 5's founding as a "crowning achievement" for McWilliams that would not have happened "without his commitment and dedication."100

\footnotetext{
${ }^{96}$ Cal Hudson, "March and April General Membership Meetings," Bridges, May/June 2001, 6.

${ }^{97}$ Hudson, "March and April General Membership Meetings," 6.

${ }^{98}$ Hudson, "March and April General Membership Meetings," 6.

${ }^{99}$ McWilliams, Local 5 Oral History Project, 7-10, 15-17.

100 Olney, Local 5 Oral History Project, June 3, 2002, 5-7, 22-24.
} 
Despite this success and other new organizing campaigns, the ILWU's membership voted against McWilliam's bid for a third term in office. Only three days after Local 5 reached a tentative agreement with Powell's Books, sitting Vice President and McWilliams challenger James Spinosa won 61 percent of the vote to unseat the incumbent president. ${ }^{101}$ In his final report to the membership in the union newspaper, the outgoing official addressed the disturbing trends he observed within the union. At the top of McWilliams' list was low member participation and voter turnout for the union election, which totaled only 20 percent of the membership. "What we are witnessing is the withering away of a dynamic democracy," stated McWilliams. ${ }^{102}$ He went on to denounce the narrow self-interest of those factions with the ILWU that criticized the union's new organizing initiatives as competing against the interest of the current membership.

As for the booksellers of Powell's, seemingly nothing could disrupt their aspirations for Local 5 or confidence in its future. When asked about the next steps for Local 5 in the spring of 2001, union President Mary Winzig expressed only excitement and confidence in the local's future. "It's not going to stop here, it can't," Winzig stated, "it's too big of a movement." The campaign and Local 5 "captured the imagination" of onlookers and the labor movement, because she declared:

a bunch of booksellers stood up to a multi-millionaire and did creative things. We didn't do the normal union type tactics, and because we are such an economy based on service, we definitely are going way beyond this. [...] We are going out here actively hoping to have people join up with Local 5. We want to start a retail association, we want to work more closely with other groups. [...] We want to be a

\footnotetext{
${ }^{101}$ Dan Weikel, "Challenger Spinosa Is Elected Chief of Longshore Union," Los Angeles Times, August 5, 2000, http://articles.latimes.com/2000/aug/05/business/fi-64997.

${ }^{102}$ Brian McWilliams, "Beyond the Election," The Dispatcher, July-August 2000, 2.
} 
respected force in this community, and we want to do it right. [...] We have to go beyond Powell's Books [...]. ${ }^{103}$

Winzig's described visiting the ILWU's library in San Francisco after the contract campaign and the moment she realized the historical significance of the Powell's booksellers' actions. While there, she saw a display case with a Local 5 button placed alongside other medallions from the union's past, prompting her to consider the "blending of past and future, longshore workers and booksellers." 104 With their union and contract certified in writing, Local 5 set itself to the task of organizing the unorganized and preparing for its next round of contract bargaining in three years.

${ }^{103}$ Winzig, ILWU Oral History Collection, Tape 3-4, 25-28.

104 Winzig, ILWU Oral History Collection, Tape 3-4, 25-28. 


\section{Conclusion}

The Powell's Books union campaign represents an indispensable Portland contribution to the reinvigorated global and national labor movement of the late 1990s. This new wave of union activity included unprecedented efforts to organize bookstores throughout the nation. Unexpectedly, employees at Borders Books, Barnes \& Noble, and Powell's Books initiated two dozen union drives across the country between 1996 and 2004. At times, the bookstore campaigns seemed like breakthrough moments for a labor movement that struggled to organize the retail sector. In fact, many of the most notable campaigns were initiated not by union staff organizers but by rank-and-file bookstore clerks, who used the internet to share information, coordinate actions, and create informal national bookstore unions. Yet the only bookstore union that organized during this era and remains today is ILWU Local 5 at the Powell's Books chain. This campaign succeeded where other bookstore campaigns failed because the ILWU and the Portland labor community 1) prioritized the development of the workers' organizing skills and confidence during the election campaign and 2) collaborated to create a social movement that put sufficient economic and social pressure on the bookstore's local ownership. Ultimately, while a collision of factors within the bookselling sector of the economy and the labor movement produced the Powell's union recognition campaign, a confluence of action, purpose, and unity by social justice organizations spelled success for Local 5 during contract bargaining.

Although Mary Winzig described the Powell's campaign as unique, she clarified her assessment by noting that "every organizing drive is unique, but every organizing 
drive is the same." ${ }^{1}$ This circular assessment became a driving point of inquiry for this thesis. However, the fact that the labor movement had never seen a campaign like the struggle conducted by Local 5 meant that while many facets of the union drive served as exemplar lessons for organized labor to heed, the context of the struggle prevented it from representing a road map to unionization for other workers or for the revitalization of the labor movement more broadly.

Michael Powell's accelerated corporatization initiatives for his regional bookstore chain in the 1990 s were a response to the rapid and intense economic conglomeration of bookselling advanced by the Borders Group, Barnes \& Noble, and Amazon. Furthermore, Powell's countered advances by his competitors in computer technology with a corporate realignment of his chain's labor process in the 1990s. Rather than get left behind, Powell embraced computerization of his vast inventory, online bookselling, and increased corporate control as well as the rationalization of the labor process inside his stores. Nevertheless, these changes compelled resistance from employees, culminating in a union campaign led by his booksellers. The labor dispute became the store's central issue for nearly two years, raising questions about the long-term viability of the Portland cultural institution.

The union aspirations of Powell's employees were not an aberration in bookselling, but emblematic of a national trend among booksellers in this era. These booksellers considered unionization indispensable to them as workers and to their position within the transmission of literary culture during a tumultuous era of

\footnotetext{
${ }^{1}$ Peter Olney, interviewed by Harvey Schwartz, Local 5 Oral History Project, ILWU Archive, San Francisco, Calif., June 3, 2002, 13.
} 
bookselling. In response to the conglomeration of the industry, the occupational identity of booksellers in the late 1990s and early 2000s embraced a certain air of resistance to corporatization and globalization. Such developments led to the remarkable rise in the number of attempts to unionize around the occupation of bookselling. Segments of the Borders and Barnes \& Noble workforce found commonality of cause and experience, organizing informal national booksellers' unions through the internet. These organizing initiatives, in particular the campaign at Powell's, responded to businesses' attempts to incorporate booksellers' knowledge and expertise into computer systems and centralize the labor process under management's direction. When these conditions, which allowed employers to transform the duties of retail workers duties into something akin to factory work (forecasted by political economist Harry Braverman's in the 1970s) arrived to the bookselling sector in the 1990s, booksellers across the country including hundreds in Portland enlisted in the labor movement. ${ }^{2}$

Workers and disaffected union militants, either on the margins of organized labor or wholly excluded, initiated the revitalization of the labor movement in the 1990s. Workers centers, living wage coalitions, and organizations such as Jobs with Justice and the reinvigorated Industrial Workers of the World (IWW), provided unorganized employees and those union-activists demoralized by the AFL-CIO's seemingly out of touch relationship with the American working-class the means to challenge an increasingly globalized corporate business community on the grassroots level. The AFLCIO's New Voice slate unseated the union's entrenched leadership in 1995 and carried

\footnotetext{
${ }^{2}$ Harry Braverman, Labor and Monopoly Capital: The Degradation of Work in the Twentieth Century (New York: Monthly Review Press, 1974), 371.
} 
out a series of reforms over the next three years that prioritized more funding and recruitment for new organizing campaigns. By the time the Powell's booksellers sought union representation in 1998, these national and local developments had staged resources and networks of support for new campaigns like the one that emerged at Powell's Books.

The ILWU, UFCW, and Teamsters all contributed to this era of new organizing, including in the bookselling sector. However, only the ILWU achieved anything but fleeting results in the labor movement's attempts to unionize the nation's bookstores. The West Coast longshore union's organizing success was primarily the product of the union's Organizing Department under President Brian McWilliams between 1994 and 2000. Under the direction of McWilliams, the ILWU outreached to unorganized workers with the goal of pulling up into its ranks as many workers as possible. The union contributed a third of the international's budget to organizing and provided unwavering support to new organizing projects such as the Powell's Book campaign.

Powell's efforts to thwart the ILWU after the union's narrow election victory proved a decisive failure and, on the contrary, the company's actions polarized a super majority of the workforce behind Local 5. Although a surface reading of the April 1999 union election results suggested Powell's employees were evenly divided between the company and the union, the truth of the matter was that a significant number of "No" votes remained on the fence and open to persuasion. Indeed, management miscalculated its support among employees and further degraded bookseller loyalty to the company through its dismissive and retaliatory actions during the contract campaign, such as the termination of union leader Marty Kruse in October 1999. Case in point, booksellers regularly credited Powell's attorney Larry Amburgey's caustic conduct at bargaining 
sessions as a prime motivator for siding with the union. The combined impact of management's missteps in the contract bargaining era unified booksellers around Local 5 and almost guaranteed the union's victory if the Local could maintain its organizing pace.

The Local 5 union campaign forced Portland's self-identified liberals and progressives, some of whom had only a superficial appreciation for unions, to confront the issue of economic class publicly in their city's "living room." Do workers who labor for benevolent liberal business owners deserve the same solidarity from liberals and progressives given to other more precarious or disadvantaged employees? This dilemma played out in the editorials and published letters to local newspapers, as well as among politicians and civic leaders. However, no other Portland liberal felt the blunt edge of this quandary more than Michael Powell, who had regularly recognized the role of unions in his civic pursuits but expressed cynicism and bewilderment at why such measures were necessary at his store. "It's ironic that I'd be attacked by labor as a capitalist running dog," stated Powell. ${ }^{3}$

Although Powell did respond to the union challenge with several textbook union avoidance strategies, the civil liberties advocate was unwilling to completely sacrifice his liberal reputation and public identity for the cause of defeating the union. In fact, this provided Local 5 an advantage throughout the labor dispute. Whereas most employers confronted with a union election take an aggressive position at the outset of a union threat before the labor organization takes advantage of an opportunity to position itself as a legitimate power in the workplace, Powell attempted to appeal to the workers on a personal and intellectual level during the election campaign only to lose by a few votes.

\footnotetext{
${ }^{3}$ Gail Kinsey Hill, "The Book on Michael Powell," Oregonian, August 15, 1999, Business, A01.
} 
In comparison, Powell distanced himself from the subsequent contract bargaining dispute and relied on intermediaries, surrogates, and allies within the community to discredit the union. Yet, the company's aggressive actions, including policy changes and the firing of Marty Kruse, had the opposite of the intended effect during the contract struggle. Rather than invalidate the Local 5, these actions reinforced in the minds of a growing number of booksellers the practical necessity of the union. While Powell's strategy failed to prevent the union from acquiring a contract, it did allow the bookstore owner to preserve his liberal reputation within the community.

The wellsprings from which the Powell's booksellers derived their organizing success were their initiative, self-organization, and unrelenting creativity in planning collective actions. Particularly during the period of contract negotiations with management, Local 5's ability to organize creative actions with varying levels of intensity and militancy allowed workers to act accordingly to their comfort level. Beginning with a ten-minute break-out or a read-in, then escalating to a walk-out to attend a bargaining session, and then finally taking part in street theater or ULP strikes to disrupt business, Local 5 introduced unionism to booksellers through imaginative and empowering collective actions that aligned with the culture of the store and its employees. While the union-activists wrote prolifically about the organizing campaign and contract negotiations, workers' consciousness about the amount of power they could wield if they acted in concert with each other, other unions, and the broader community accelerated through direct action. In the fullest sense of historian Alan Trachtenberg's descriptive explanation of a workers' strike, Local 5's work stoppages represented a 
"rupture" of the prevailing obedience to authority in public life and generated "a sense of positive freedom" for the union's working-class participants. ${ }^{4}$

The Powell's booksellers' selection of the ILWU as their affiliate union allowed for the workers' initiative and creativity to translate into a sense of belonging and place within the labor movement as Local 5. Despite the administrative challenges that awaited the union after they signed their first contract, the autonomy of chartering their own local allowed booksellers to enter into a new world of organized labor on their own terms and conditions. Rather, than restraining either the culture or creativity of the booksellers, the ILWU fostered its development while providing its knowledge on how to effectively take actions to win concessions at the bargaining table. The booksellers' initiation into the broader labor movement came in a series of strikes in the spring of 2000, when organized labor joined their business halting pickets. The most powerful message of solidarity came when union workers in the transportation sector refused to cross the booksellers' picket lines, temporarily shutting down crucial supply and delivery channels for the company.

Paramount to Local 5's success and ability to change the economic possibilities for future Powell's employees was the union's partnership with Portland's social justice community that induced a social movement around Powell's Books and its workers. Local 5's collaboration with Jobs with Justice and the Art \& Revolution Collective proved integral in catapulting the campaign from an isolated workplace struggle into a cause célèbre for the city's progressive, anti-globalization movement. From the outset, Powell's employees possessed the wherewithal to link their union effort's success to the

${ }^{4}$ Alan Trachtenberg, The Incorporation of America: Culture and Society in the Gilded Age (New York: Hill and Wang, 1982), 89. 
support of the local community. The booksellers' first call after deciding to organize was not to a union but to Portland's branch of Jobs with Justice, an organization that represented labor's leadership in rank-and-file cross community alliances. Activist artists from Portland's Art \& Revolution Collective produced unforgettable imagery and choreography that communicated the union's goals to an attentive city populace. These and other partnerships resulted in a network of sympathetic customers willing to disrupt business and even boycott the store if necessary.

In trying to account for why contract negotiations took so long, critics may contend that the direct-action tactics of union and its allies stiffened the resistance of Powell's management and delayed resolution. In part, this explanation assumes that both sides possessed an equal share of the power engendered in time. On the contrary, until both sides reached an agreement, the union's power remained tenuous and, thus, management possessed an overwhelmingly advantage regarding time. Therefore, the company held a definite interest in prolonging contract negotiations for as long as possible in hopes that the union would either lose momentum and sign a weak contract or fall victim to a decertification campaign, as other bookstore unions in this era experienced.

Instead, Local 5 used public demonstrations to assert immediate pressure on Michael Powell and allies in the wake of such actions to spur collateral pressure from the community. Whereas Michael Powell and his store's management were the public targets, the audiences for these actions were as equally influential and included both employees and the general community. Between October 1999 and May 2000, bookseller participation in the union's actions steadily increased which generated a sense of unity 
among workers. Furthermore, the pickets and strikes lead by the labor community and street theater conducted by Art \& Revolution defused the in-store tension between the union and Michael Powell through the broader Portland community. This approach provided liberal community leaders the preconditions to intervene publicly, particularly through Jobs with Justice's Workers' Rights Board hearing, and call upon Michael Powell to end the contract dispute by compromising with the union.

The World Trade Organization (WTO) protests in Seattle in 1999 and Portland's revival of May Day in 2000 also forged the bonds of solidarity and mutual aid between Local 5 and its community allies. Few other events of the 1990s inspired as much imagination or righteousness within the anti-globalization movement as the WTO protests. The choreography and effectiveness of the protests, plus the incidents of property destruction and police violence captured on television, raised the nation's awareness of the activities of the WTO and globalization. Yet, these same factors contributed to the growing militarization of local police forces in the early 2000s and changed how cities and law enforcement agencies planned for and policed political demonstrations. Case in point, the City of Portland and its police department were influenced by and used the property destruction that occurred during the WTO protests as justification for their preparations and response to May Day 2000. Despite these efforts, and possibly a byproduct, Portland's May Day became etched into the historical memory of the city's progressive and radical communities. Thereafter, the holiday has grown in numbers in Portland and continues to provide anti-capitalists, immigrant rights activists, and unionists an annual day of celebration, protest, and confrontation with the police. 
Local 5's strategic use of Unfair Labor Practices (ULP) provided the union with the justification and security to take progressively bolder economic actions that ultimately were responsible for the union's headway at the bargaining table. In this regard, the ILWU took advantage of management's inexperience in the field of labor relations and trained booksellers to recognize and respond to the company's ULPs. Conversely, the booksellers distinguished themselves as quick studies of labor law, filing ten ULPs within the eight months between October 1999 and May 2000. These allegations became the justification for eleven union work stoppages during the same time period, beginning with a modest ten-minute "break-out" in protest of Marty Kruse's firing. Subsequent work stoppages involved greater intensity and escalated the economic and social pressure upon Michael Powell to sign a contract with the booksellers. Local 5 demonstrated that the strike, the collective withholding of labor power for even the briefest of moments, remained workers' most valuable tool to wrench improved conditions from an employer.

Through their actions on the picket line and contributions at the bargaining table, women booksellers and staff organizers demonstrated that their leadership drove the union campaign's success. When the ILWU's Marcy Rein was in Portland for the campaign, she recalled thinking of her fellow organizers as the "fabulous all-girl organizing team" because by the end of the contract campaign most of the organizing team members were women. ${ }^{5}$ Rein described the collaborative efforts of the skilled ILWU staffers Anissa Couey and Patricia Schultz; Jobs with Justice organizer Margaret

\footnotetext{
${ }^{5}$ Marcy Rein, interviewed by Harvey Schwartz, Local 5 Oral History Project, Anne Rand Library, International Longshore and Warehouse Union, San Francisco Calif., June 14, 2002, 13.
} 
Butler; and the numerous women booksellers and union activists as "refreshing." Union women, in particular, turned out in numbers to solidarity actions for the Local 5 booksellers, including a picket in July by 150 women in town attending the AFL-CIO's Western Regional Summer Institute for Union Women. ${ }^{7}$

An analysis of Local 5's document archive combined with the union activists' oral narratives illustrates the formation of a distinct working-class culture and consciousness among Powell's booksellers. In fact, the rhetoric utilized by the union, company, media, and public revealed that all parties involved conceived of the labor dispute as a cultural content. The values and perspectives communicated through workers' essays, artwork, strikes, and solidarity actions with the social justice community demonstrate a collective occupational identity and resistance to corporatization. On its part, Powell's management dismissed the workers' vision as incompatible with uncompromising retail market forces and the store's collegiate work environment. The company's growth and continued leadership in the retail book sector amidst the union's continued presence within the workplace suggests that the contest did not adversely affect the store or the public's loyalty to the business. Historians in the future may well determine that the unionization and subsequent compromises contributed to the store's financial successes during the years that followed. Nevertheless, the coexisting cultures proceed accordingly to their respective contractual powers in the workplace, colliding every so often into a labor dispute.

\footnotetext{
${ }^{6}$ Rein, Local 5 Oral History Project, 13.

${ }^{7}$ Mary Winzig and Marcy Rein, "Labor Board Cites Powell's Management for Discrimination," Press Release, ILWU Library, ILWU Local 5 Document Archive, July 11, 2000.
} 
The transition from the fight for the union to the administration of the union's affairs proved challenging for Local 5. While this is not entirely uncommon for a new union, the fact that the booksellers chartered their own local made the change proportionally more difficult. The union activists responsible for initiating the organizing campaign and who successfully bargained the contract overwhelming remained involved within the local as officers and stewards, providing much needed continuity for the union. Disagreements over contract interpretation provided fodder for the local to mobilize the membership into union activity and continued to provide opportunities for the more militant-activists members to take actions. However, the unexpected addition of two new bargaining units, hundreds of miles away in opposite directions, into Local 5 so soon after the Powell's contract agreement put its new leadership in an unfamiliar terrain. The Powell's workers' transition from organizing to administration following the signing of their first contract raises questions for historians not addressed in this thesis. The topics of how the booksellers secured a second contract, handled changes in leadership, and attempted to achieve their aspirations for spearheading a new era of retail unionism that happened to coincide with foreign wars and a domestic Great Recession appear particularly ripe for future historical inquiry.

$* * *$

During the three years following the signing of a contract, the United States underwent a dramatic political and economic change. The country experienced an economic recession in 2001 followed by the nation's entry into two wars linked to the aftermath of the September 11th terrorist attacks on the U.S. mainland. In response, the ILWU and Local 5 took an oppositional stance to President George W. Bush's war in 
Iraq. Closer to home, a majority of workers at the South Coast Hospice voted to decertify the ILWU as its union in August 2002, only ten months after signing their first contract. As the Powell's booksellers grappled with administering the affairs of the local during a time of recession and war, the booksellers continued to build and organize their union in preparation for their second round of contract negotiations. When Powell's management and Local 5 met in July 2003 to begin bargaining for a second contract, both sides expressed hope for a far less acrimonious experience this time around. However, negotiations proved as equally difficult as before, stretching on until March 2004 before both sides reached an agreement. Wages and health care again became sticking points. Consequently, the union returned to the picket line and conducted two ULP strikes in November that brought the labor dispute back into the local spotlight.

As historians begin to evaluate the labor movement in the 1990s, the national wave of bookstore union campaigns that occurred at the decade's close merits concerted inquiry. Despite the many defeats, these bookstore organizing campaigns remain significant because of the booksellers' creative and trailblazing use of the internet as an organizing tool. Furthermore, Local 5's successful union drive at Powell's Books stands out as a point of light against a dark backdrop of failed retail organizing campaigns across the nation. With over three hundred workers, the Powell's bargaining unit was larger than any other bookstore campaign of its time. Moreover, Local 5 is the only union from this era of bookstore organizing to still exist today. Indeed, the UFCW's strategy of targeting a corporation's public image and pressuring a company into a neutrality agreement to facilitate worker organizing has proved effective for certain union drives. Nevertheless, ILWU Local 5's experience illustrated the value of a worker-centered 
strategy that takes direct action alongside community partners. The retail sector is currently the largest employer in the U.S. and has a miniscule union density rate of 5 percent. ${ }^{8}$ If organized labor hopes to regain its influence within the retail sector, society, and among the unorganized working-class, greater analysis of the national bookstore union wave of the 1990s and the Powell's Books campaign can help illuminate a path forward for the labor movement.

${ }^{8}$ Seth Kershner, "Breaking the Chains: Can Labor Unions Organize Retail Workers," In These Times, January 6, 2017, accessed April 22, 2017,

http://inthesetimes.com/working/entry/19779/breaking_the_chains_can_labor_unions_organize_retail _workers. 


\section{Bibliography}

\section{ILWU Oral History Collection}

Schwartz, Harvey interview with Mary Winzig. ILWU Oral History Collection. Anne Rand Library, International Longshore and Warehouse Union. San Francisco, Calif. June 11, 2001.

\section{ILWU Local 5 Oral History Project}

Beechert, Edward interview with Cal Hudson. ILWU Local 5 Oral History Project. Anne Rand Library, International Longshore and Warehouse Union. San Francisco, Calif. May 20, 2001.

interview with Carole Reichstein. ILWU Local 5 Oral History Project. Anne Rand Library, International Longshore and Warehouse Union. San Francisco Calif. April 17, 2002.

interview with Jeff Hensley. ILWU Local 5 Oral History Project. Anne Rand Library, International Longshore and Warehouse Union. San Francisco Calif. November 19, 2001.

interview with Jim Cowing. ILWU Local 5 Oral History Project. Anne Rand Library, International Longshore and Warehouse Union. San Francisco, Calif. August 28, 2001.

interview with John McMahon. ILWU Local 5 Oral History Project. Anne Rand Library, International Longshore and Warehouse Union. San Francisco, Calif. November 19, 2001.

interview with Marty Kruse. ILWU Local 5 Oral History Project. Anne Rand Library, International Longshore and Warehouse Union. San Francisco Calif. April 20, 2002.

interview with Mary Winzig. ILWU Local 5 Oral History Project. Anne Rand Library. International Longshore and Warehouse Union. San Francisco Calif. August 20, 2001.

interview with Mary Zartman. ILWU Local 5 Oral History Project. Anne Rand Library, International Longshore and Warehouse Union. San Francisco Calif. April 12, 2002.

interview with Meredith Schafer. ILWU Local 5 Oral History Project. Anne Rand Library, International Longshore and Warehouse Union. San Francisco Calif. August 21, 2001.

interview with Michael Cannarella ILWU Local 5 Oral History Project. Anne Rand Library, International Longshore and Warehouse Union. San Francisco Calif. September 4, 2002. 
interview with Ryan Takas. ILWU Local 5 Oral History Project. Anne Rand Library, International Longshore and Warehouse Union. San Francisco Calif. April 26, 2001.

Schwartz, Harvey interview Peter Olney. ILWU Local 5 Oral History Project. Anne Rand Library, International Longshore and Warehouse Union. San Francisco, Calif. June 3, 2002.

interview with Brian McWilliams. ILWU Local 5 Oral History Project. Anne Rand Library, International Longshore and Warehouse Union. San Francisco, Calif. July 19, 2002.

interview with Marcy Rein. ILWU Local 5 Oral History Project. Anne Rand Library, International Longshore and Warehouse Union. San Francisco, Calif. June 14, 2002.

\section{Archival Sources}

ILWU Local 5 Document Archive. Anne Rand Library. International Longshore and Warehouse Union, San Francisco, California.

KBOO Community Radio Archive. KBOO FM, Portland, Oregon.

May Day. A2005-004, 2000. City of Portland (OR) Archives, Portland, Oregon.

Police-May Day 2000. A2008-012. City of Portland (OR) Archives, Portland, Oregon.

Portland Police Bureau. Record Series 8000-02. City of Portland (OR) Archives, Portland, Oregon.

\section{Government and City Records}

Gleason, Caroline. "For Working Women in Oregon Revised Code of Ruling on Wage, Hour and Sanitary Conditions Issued by the Industrial Welfare Commission." The Survey Vol. XXXVI, September 9, 1916.

Hirsch, Barry T. and David Macpherson. "Union Membership, Coverage, Density, and Employment by Metropolitan Area and Sector, 1986-2014," Union Membership and Coverage Database from the CPS. Accessed May 27, 2016, http://unionstats.com/.

Hoff, O.P. Sixth Annual Report of the Bureau of Labor Statistics and Inspector of Factories and Workshops of the State of Oregon. Salem, Oregon: State Printing Department, 1914.

Mayer, Gerald. Union Membership Trends in the United States. Washington, D.C.: Congressional Research Service, 2004.

National Labor Relations Board. Fifty-Ninth Annual Report of the National Labor Relations Board for the Fiscal Year Ended September 30, 1994. Washington, D.C.: U.S. Government Printing Office, 1995. Accessed January 16, 2017. 
https://www.nlrb.gov/sites/default/files/attachments/basic-page/node1677/nlrb1994.pdf.

National Labor Relations Board. Sixty-Fourth Annual Report of the National Labor Relations Board for the Fiscal Year Ended September 30, 1999. Washington, D.C.: U.S. Government Printing Office, 2001.

R.L. Polk \& Co. Portland (Multnomah County, Ore.) City Directory. Kansas City, Mo.: R.L. Polk, 1974-1983.

Secretary of State, Voters' Pamphlet: Measures, Vol. 1. Salem, Oregon: State of Oregon, 1996. Accessed December 26, 2016, http://library.state.or.us/repository/2010/201003011350161/.

U.S. Bureau of Labor Statistics. "Retail Trade: NAICS 44-45," Industries at a Glance. Washington, D.C.: U.S. Department of Labor, March 4, 2016. Accessed March 7, 2016. http://www.bls.gov/iag/tgs/iag44-45.htm.

U.S. Bureau of Labor Statistics. "Table 1. Work Stoppages Involving 1,000 or More Workers, 1947-2015.” Economic News Release. Washington, D.C.: U.S. Department of Labor, last modified February 10, 2016. Accessed May 27, 2016. http://www.bls.gov/news.release/wkstp.t01.htm.

U.S. Bureau of Labor Statistics. "Unemployment Rate in Portland-Vancouver-Hillsboro, OR-WA (MSA) [PORT941URN]”, retrieved from FRED, Federal Reserve Bank of St. Louis. Accessed December 26, 2016. https://fred.stlouisfed.org/series/PORT941URN.

U.S. West Dex, Inc. The Yellow Pages Portland. Englewood, Colorado: U.S. West Dex 1998.

\author{
Media Sources \\ Arlington Morning News (Arlington, Texas) \\ Chicago Tribune \\ C-NET News.com \\ Dissent \\ Forbes \\ In These Times \\ Inc. \\ LA Weekly \\ Labor Notes \\ Los Angeles Times
}




\author{
New York Times \\ Northwest Labor Press \\ Oregon Business \\ Oregonian \\ Poets \& Writers \\ Portland Business Journal \\ Portland Monthly \\ PR Newswire \\ Publishers Weekly \\ Puget Sound Business Journal \\ Revolutionary Worker \\ School Library Journal \\ Seattle Union Record \\ The Courier-Journal (Louisville, Kentucky) \\ The Dispatcher \\ The Nation \\ The Portland Alliance \\ The Progressive \\ Vancouver Sun (British Columbia, Canada) \\ Wall Street Journal \\ Willamette Week \\ Workers World \\ Website Archives
}

“02 24 00.” YouTube video, 1:09:06. Posted by “ilwulocalfive,” November 16, 2012. https://youtu.be/BLGF2O1Qbrw.

"1999 Portland Gay History Walking Tour." Gay and Lesbian Archives of the Pacific Northwest. Last modified 2011. Accessed May 26, 2016.

http://www.glapn.org/6045walkingtour.html.

"Collective Bargaining Agreement between Powell's Books, Inc. and International Longshore and Warehouse, Local 5," ILWU Local 5. August 14, 2000.

http://www.powellsunion.com:80/Contract.txt. Accessed September 20, 2017. 
https://web.archive.org/web/20020207230844/http://www.powellsunion.com:80 Contract.txt.

"Day 2 Rebuttal to Amazon.com Management's FAQ." WashTech/CWA. Last modified December 28, 2000. http://www.washtech.org/day2/122800_rebuttal.html. Accessed May 27, 2016. Internet Archive. https://web.archive.org/web/20010408025647/http://www.washtech.org/day2 /122800_rebuttal.html.

"ILWU Local 5: Victory at Powells 2000.avi." YouTube video, 41:48. Posted by "ilwulocalfive," October 24, 2012. https://youtu.be/VaeNCAX2z2U.

"Jim Cowing on Local 5." YouTube video, 32.38. Posted by “ilwulocal5," October 31, 2012. https://youtu.be/6dLVWXy7Ee0.

"Margaret Butler on the Founding of ILWU Local 5." YouTube video, 18:02. Posted by "ilwulocalfive," October 24, 2012. https://youtu.be/4jeWAXojrug.

"Mission Statement." Union of Radical Workers and Writers. Last updated March 24, 2005. Accessed May 27, 2016. http://urww.blogspot.com/2005/03/union-ofradical-workers-and-writers.html.

"Portland May Day 2000 from A Year in the Streets." YouTube video, 3:59. Posted by "Under Story Productions," March 5, 2010. https://www.youtube.com/watch?v=QVxXQGEbuC0.

"Powell's City of Books." C-SPAN 2: Book TV. Filmed February 27, 1999. Accessed January 7, 2017. https://www.c-span.org/video/?120959-1/powells-city-books.

"Shelly Herochik." Twiford Funeral Home. Published January 16, 2009. Accessed September 20, 2017. https://www.twifordfh.com/shelley-herochik/.

"Statement of Douglas H. Dority International President United Food and Commercial Workers International Union (UFCW) Rally for Borders Employees." Press Release. October 1, 1997. UFCW. http://ufcw.org/100197.html. Accessed May 27, 2016. Internet Archive. https://web.archive.org/web/19980213095138/http://ufcw.org/100197.html.

“The Child Online Protection Act." Powell's Books. http://www.powells.com/cdatoo.html. Internet Archive. Accessed January 17, 2017. https://web.archive.org/web/19991012192033/http://www.powells.com /cdatoo.html.

“USNLRB Case 9-CA-35548." Affidavit, http://booksellersunion.org/affidavit.html. Accessed May 27, 2016. Internet Archive. https://web.archive.org/web/20160115071847/http://booksellersunion.org laffidavit.html. 
Appleman, Eric M. "Democracy Rising 'People Have the Power Tour' 2001-2003," Democracy in Action. Accessed January 17, 2017. http://www.gwu.edu/ action/2004/nader/naderrallies.html.

Bigman, Paul. "Organizing Victory in Olympia!” Organize Your Workplace. ILWU Local 19. Accessed September 17, 2017, https://www.ilwu19.com/organize/olympia.htm.

Cascadia Media Collective. A Year in the Streets (2001). Accessed October 5, 2017. https://www.youtube.com/watch?v=QVxXQGEbuC0.

Diamond, Norman. "Portland Labor History Tour." Lewis \& Clark College. May 2001. Accessed May 13, 2015. http://college.lclark.edu/programs/political_economy/student_resources/labor tour/.

Grogan, David. "Authors, ABA to DOJ: Investigate Amazon's Abuse of Its Dominance in the Book Market," Bookselling this Week. American Booksellers Association. July 13, 2015. Accessed May 26, 2016. http://www.bookweb.org/news/authorsaba-doj-investigate-amazon\%tE2\%80\%99s-abuse-its-dominance-bookmarket\#Authors United Letter.

Heinzkill, Richard. "A Brief History of Newspaper Publishing in Oregon.” University of Oregon. August 1993. Accessed May 13, 2016. https://library.uoregon.edu/govdocs/indexing/newspaperhistory.html.

Holt, Pat. "The Pacific Northwest Part II Powell's: Trouble in Paradise." Holt Uncensored. Issue \#49. March 30, 1999. Accessed December 26, 2016. http://holtuncensored.com/members/column49.html.

Kubek, Anne. Union Awareness Training for Borders Managers: Confidential Property of Borders Inc. September 1996, republished by the Industrial Workers of the World. Last modified August 5, 1998. Internet Archive. http://parsons.iww.org/ borders/manual.html. Accessed May 27, 2016. https://web.archive.org/web/20010815060549/http://parsons.iww.org/ borders Imanual.html.

Olywobs Media Collective. "Fine Host." Riff Raff. Olympia General Membership Branch, Industrial Workers of the World. Number 2. Accessed September 17, 2017. http://www.azinelibrary.org/approved/riffraff.pdf.

Olywobs Media Collective. "Fine Host." Riff Raff. Olympia General Membership Branch, Industrial Workers of the World. Number 3. Accessed September 17, 2017. http://azinelibrary.org/approved/riff-raff-3-1.pdf.

Russ, Kristen. "No Decisions About Us Without Us: A History of a Bookstore Union." No Decisions About Us Without Us: History of Local 5 - Powell's Books. ILWU Local 5. Accessed December 28, 2016. http://ilwulocal5.com/?page_id=46. 
Sampsell, Kevin. "In Memoriam: Marty Kruse.” Kevin Sampsell (blog). April 2, 2012. https://kevinsampsell.com/2012/04/02/in-memoriam/.

Schwartz, Harvey interview with Mary Winzig. "Mary Winzig and the Powell's Organizing Drive, 1998-2000." ILWU. Published April 21, 2008. Last modified August 9, 2011. http://www.ilwu.org/mary-winzig-and-the-powells-booksorganizing-drive-1998-2000/.

Skinner, Jeremy. "Book Publishing.” The Oregon Encyclopedia. Accessed May 27, 2016. http://www.oregonencyclopedia.org/articles/book_publishing/\#.V0iCbBMrLnA.

World Trade Organization. "3 December - The Final Day and What Happens Next." WTO Briefing Note. Accessed October 2, 2017. https://www.wto.org/english/thewto_e/minist_e/min99_e/english/about_e /resum03_e.htm.

WTO Accountability Review Committee. "History/Timeline." History. Accessed October 2, 2017. http://www.seattle.gov/archive/wtocommittee/history.htm\#sat2.

\section{Books \& Scholarly Articles}

Abbott, Carl. Portland in Three Centuries. Corvallis, Oregon: Oregon State University Press, 2011.

Appelbaum, Richard and Nelson Lichtenstein. "A New World of Retail Supremacy: Supply Chains and Workers' Chains in the Age of Wal-Mart," International Labor and Working-Class History 70 (Fall 2006): 106-125.

Baldoz, Rick and Charles S, Koeber. "Work, Difference, and Social Change: Two Decades after Braverman's 'Labor and Monopoly Capital,'” International Labor and Working-Class History 65 (Spring 1999): 135-138.

Bekken, Jon. "Feeding the Dinosaurs: Economic Concentration in the Retail Book Industry.” Publishing Research Quarterly (Winter 1997-1998): 3-26.

Belknap, George N. Oregon Imprints: 1845-1870. Eugene, Ore.: University of Oregon Books, 1968.

William Bigelow and Norman Diamond, "Agitate, Educate, Organize: Portland, 1934," Oregon Historical Quarterly 89, no. 1 (1988): 16-27.

Boehmer, Gabriel H. City of Readers: The Book Lover's Guide to Portland. Portland, Ore: Tall Grass Press, 2006.

Bossen, Colin. "The Chicago Couriers Union, 2003-2010: A Case Study in Solidarity Unionism," WorkingUSA 15 (June 2012): 197-215.

Brandt, Richard L. One Click: Jeff Bezos and the Rise of Amazon.com. New York: Penguin Group Inc., 2011. 
Braverman, Harry. Labor and Monopoly Capital: The Degradation of Work in the Twentieth Century. New York: Monthly Review Press, 1974.

Buchanan, Roger. Dock Strike: History of the 1934 Waterfront Strike in Portland, Oregon. Everett, Washington: The Working Press, 1975.

Burke, Lucas N.N. and Judson L. Jeffries, The Portland Black Panthers: Empowering Albina and Remaking a City. Seattle: University of Washington Press, 2016.

Cobble, Dorothy Sue. Dishing It Out: Waitresses and Their Unions in the Twentieth Century. Chicago: University of Illinois Press, 1991.

Coser, Lewis A., Charles Kadushin, Walter W. Powell. Books: The Culture and Commerce of Publishing. New York: Basic Books, Inc., 1982.

Coulter, Kendra. Revolutionizing Retail: Workers, Political Action, and Social Change. New York: Palgrave Macmillan, 2014.

DeMaria, Alfred T. Combating the Resurgence of Organized Labor: A Modern Guide to Union Prevention. New York: Communications Training Institute, 1998.

DeMaria, Robert Jr. "Book Collecting and the Book as Object" In A History of the Book in America. Vol. 5, The Enduring Book: Print Culture in Postwar America, edited by David Paul Nord, Joan Shelley Rubin, and Michael Schudson, 472-84. Chapel Hill, N.C., University of North Carolina Press, 2009.

Donnelly, Robert C. Dark Rose: Organized Crime and Corruption in Portland. Seattle: University of Washington Press, 2011.

Dubofsky, Melvyn. We Shall be All: A History of the IWW. New York: New York Times Book Co., 1968.

Fine, Janice. Worker Centers: Organizing Communities at the Edge of the Dream. Ithaca, N.Y.: Cornell University Press, 2006.

Glaberman, Martin. Punching Out and Other Writings. Edited by Staughton Lynd. Chicago: Charles H. Kerr Publishing Company, 2002.

- Wartime Strikes: The struggle against the no-strike pledge in the UAW during World War II. Detroit, Michigan: Bewick Editions, 1980.

Grugulis, Irena and Öbdül Bozkurt, ed. Retail Work. New York: Palgrave Macmillan, 2011.

Gutman, Herbert G. Work, Culture, and Society in Industrializing America. New York: Vintage Book, 1977.

Hauser, Susan G. Pickets, Pistols and Politics. Portland, Oregon: Portland Police Association, 1996. 
Helquist, Michael. Marie Equi: Radical Politics and Outlaw Passions. Corvallis, Oregon: Oregon State University Press, 2015.

Herod, Andrew. "Workers as Geographical Actors," Labor History 53 (August 2012): 335-353.

-. "Workers, Space, and Labor Geography," International Labor and WorkingClass History 64, Workers, Suburbs, and Labor Geography (Fall 2003): 112-138.

Hinshaw, John and Paul Le Blanc, ed. U.S. Labor in the Twentieth Century: Studies in Working-Class Struggles and Insurgency. New York: Humanity Books, 2000.

Hochschild, Arlie Russell. The Managed Heart: Commercialization of Human Feeling. Berkeley, Calif.: University of California Press, 1983.

Johns, Rebecca A. "Bridging the Gap between Class and Space: U.S. Worker Solidarity with Guatemala," Economic Geography 74 (July 1998): 252-271.

Johnston, Robert D. The Radical Middle Class: Populist Democracy and the Questions of Capitalism in Progressive Era Portland, Oregon. Princeton, New Jersey: Princeton University Press, 2003.

Jones, Gareth Stedman. Languages of Class: Studies in English Working Class History, 1832-1982. Cambridge: Cambridge University Press, 1983.

Kessler-Harris, Alice. Gendering Labor History. Chicago: University of Illinois Press, 2007.

Larson, Eric. Jobs with Justice: 25 Years, 25 Voices. Oakland: PM Press, 2013.

LeRoy, Greg. "Smart Growth for Cities: It's a Union Thing," WorkingUSA 6 (Summer 2002): 56-76.

Levin-Waldman, Oren. The Political Economy of the Living Wage: A Study of Four Cities. Armonk, N.Y.: M.E. Sharpe, Inc., 2005.

Lichtenstein, Nelson, ed., Wal-Mart: The Face of Twenty-First Century Capitalism. New York: The New Press, 2006.

Lichtenstein, Nelson. "The Return of Merchant Capitalism," International Labor and Working-Class History 81 (Spring 2012): 8-27.

_. "Trashing Identity Politics: Does It Really Get Us Back to Class?," International Labor and Working-Class History 67 (Spring 2005): 42-49.

- The Retail Revolution: How Wal-Mart Created a Brave New World of Business. New York: Metropolitan Books, 2009.

Luce, Stephanie. Fighting for a Living Wage. Ithaca, N.Y.: Cornell University Press, 2004. 
Lynd, Staughton and Daniel Gross. "Commentary: Solidarity Unionism at Starbucks: The IWW Uses Section 7,” WorkingUSA 10 (September 2007): 347-356.

Lynd, Staughton. Solidarity Unionism: Rebuilding the Labor Movement from Below. Oakland: PM Press, 2015.

Macdonald, Cameron Lynne and Carmen Sirianni, ed. Working in the Service Society. Philadelphia, Penn.: Temple University Press, 1996.

Mantsios, Gregory, ed. A New Labor Movement for the New Century. New York: Monthly Review Press, 1998.

Martin, Andrew W. "The Institutional Logic of Union Organizing and the Effectiveness of Social Movement Repertoires," American Journal of Sociology 113 (January 2008): 1067-1103.

Miller, Laura J. "Selling the Product." In A History of the Book in America. Vol. 5, The Enduring Book: Print Culture in Postwar America, edited by David Paul Nord, Joan Shelley Rubin, and Michael Schudson, 91-106. Chapel Hill, N.C., University of North Carolina Press, 2009.

- Reluctant Capitalists: Bookselling and the Culture of Consumption. Chicago: University of Chicago Press, 2006.

Montgomery, David. The Fall of the House of Labor. New York: Cambridge University Press, 1987.

—. Workers' Control in America. New York: Cambridge University Press, 1979.

Moody, Kim. Workers in a Lean World: Unions in the International Economy. New York: Verso, 1997.

Michael Munk, 'Portland's 'Silk Stocking Mob': The Citizens Emergency League in the 1934 Maritime Strike,” Pacific Northwest Quarterly 91, no. 3 (2000) 152-160.

Nelson, Matt and Bill Nygren. Radicals in the Rose City: Portland's Revolutionaries 1960-1975. Portland, Oregon: Northwest History Press, 2013.

Nowak, Mark. "Imaginative Militancy and the Transnational Poetry Dialogue," Radical History Review (Winter 2012): 173-183.

_- "Neoliberalism, Collective Action, and the American MFA Industry," Reconstruction: Studies in Contemporary Culture 10 (2010), www.reconstruction.eserver.org/103/Nowak_02.shtml

Bill Nygren, Radicals in the Rose City (Portland, Oregon: Northwest History Press, 2013), 253-279.

Oliver, Egbert S. "Obden Dickinson and the 'Negro Question' in Salem.” Oregon Historical Quarterly 92. (Spring 1991): 4-40. 
Ortega, Bob. "Organizing Wal-Mart: An Anti-Union Company Bests Labor." WorkingUSA (January/February 1999): 41-53.

Pilcher, William W. The Portland Longshoremen: A Dispersed Urban Community. New York: Holt, Rinehart, and Winston, Inc, 1972.

William J. Pruette, Through Jaundiced Eyes: How the Media View Organized Labor (Ithaca, New York: ILR Press, 1992), 22-25.

Raff, Daniel M.G. "Superstores and the Evolution of Firm Capabilities in American Bookselling," Strategic Management Journal 21 (2000): 1043-1059.

Reynolds, David and Jen Kern. "Labor and the Living Wage Movement." WorkingUSA (Winter 2001-2002): 17-45.

Reynolds, David. "The Living Wage Movement Sweeps the Nation.” WorkingUSA (September/October 1999): 61-80.

Roediger, David R. and Philip S. Foner. Our Own Time: A History of American Labor and the Working Day. New York: Verso, 1989.

Rose, Mike. The Mind at Work: Valuing the Intelligence of the American Worker. New York: Penguin Group Inc., 2004.

Schwartz, Harvey. Solidarity Stories: An Oral History of the ILWU. Seattle: University of Washington Press, 2009.

Shantz, Jeffrey. "Anarchy in the Unions: Contemporary Anarchists at Work," WorkingUSA 12 (September 2009): 371-385.

Simon, Bryant. "Consuming Lattes and Labor, or Working at Starbucks," International Labor and Working-Class History 74 (Fall 2008): 193-211.

Slaughter, Jane ed. A Troublemaker's Handbook 2: How to Fight Back Where You Work and Win! Detroit: Labor Notes Books, 2005.

Stone, Brad. The Everything Store: Jeff Bezos and the Age of Amazon. New York: Little, Brown and Company, 2013.

Thompson, E.P. The Making of the English Working Class. New York: Vintage Books, 1966.

Thompson, Fred W. and Jon Bekken. The Industrial Workers of the World: Its First 100 Years. Cincinnati, Ohio: Industrial Workers of the World, 2006.

Trachtenberg, Alan. The Incorporation of America: Culture and Society in the Gilded Age. New York: Hill and Wang, 1982. 
van der Linden, Marcel. "Working-Class Consumer Power," International Labor and Working-Class History 46, ILWCHA Roundtable: What Next for Labor and Working-Class History? (Fall 1994): 109-121.

Vedder, Richard and Wendell Cox. The Wal-Mart Revolution: How Big-Box Stores Benefit Consumers, Workers, and the Economy. Washington, D.C.: American Enterprise Institute Press, 2006.

Weir, Stan. Singlejack Solidarity. Minneapolis, Minnesota: University of Minnesota Press, 2004.

Wilson, Gretchen and Mike Blain. "Organizing in the New Economy: The Amazon.com Campaign,” WorkingUSA (Fall 2001): 32-58.

Wright, David. "Commodifying Respectability: Distinctions at Work in the Bookshop," Journal of Consumer Culture 5 (3): 295-314. 